\title{
UC-NRLF
}

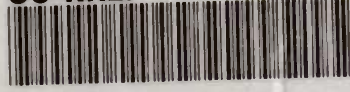

\section{B 3107879}
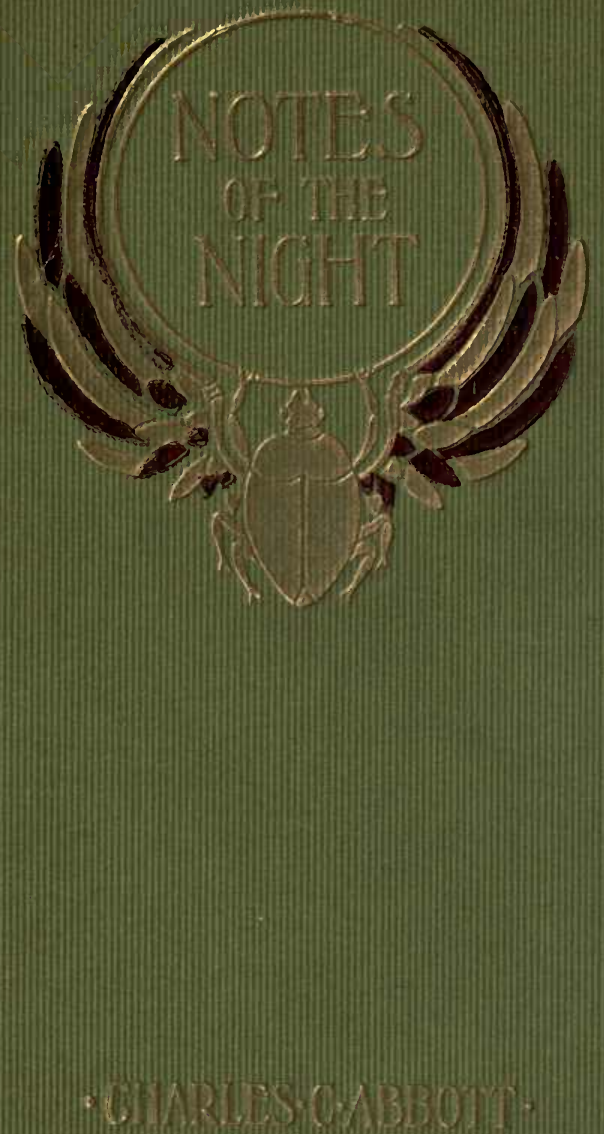


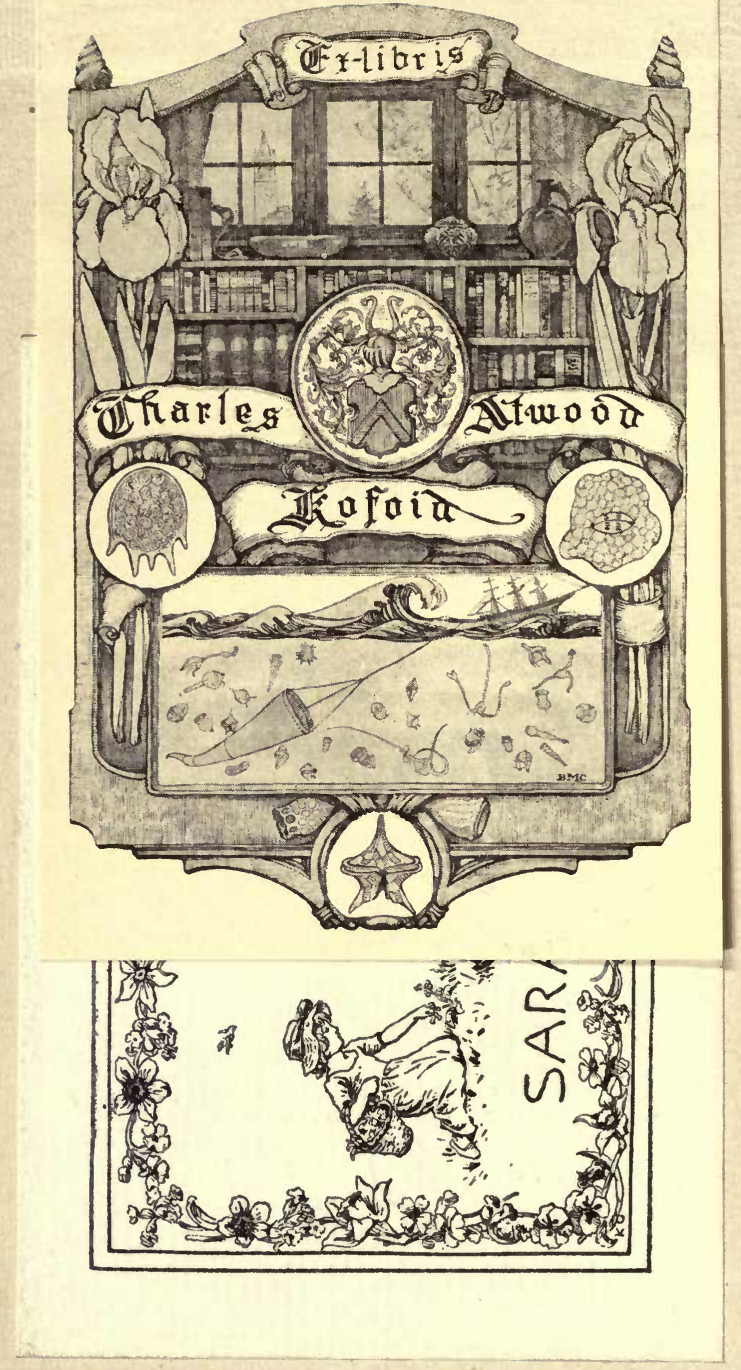




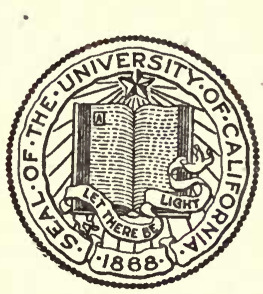

THE LIBRARY OF

\section{THE UNIVERSITY OF CALIFORNIA}

PRESENTED BY

PROF. CHARLES A. KOFOID AND MRS. PRUDENCE W. KOFOID 
and 
Nhotes of the IAight 



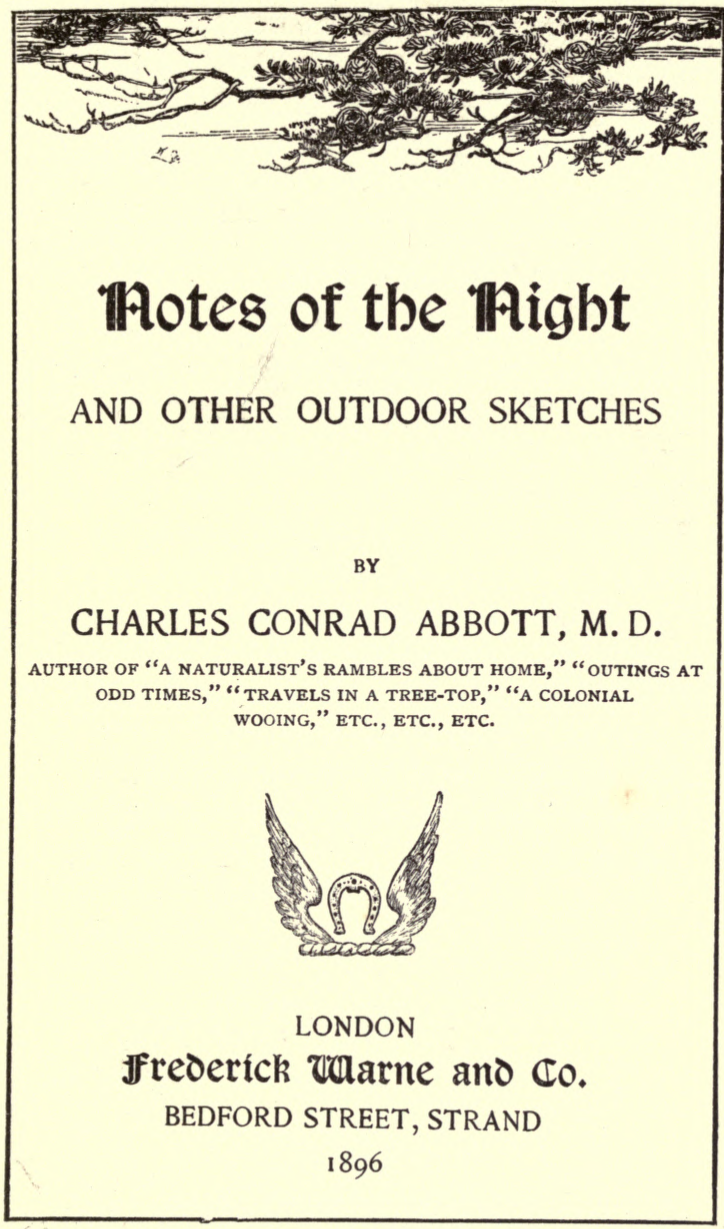


Copyright, 1895, by

J. B. Lippincott Co.

Copyright, 1896, by

The Century Co.

THE DE VINNE PRESS, NEW YORK, U. S. A. 


\section{$K-Q H 81$ \\ A215 \\ Bioloay
Library}

\section{Treface}

I TRUST the following pages need no explanaI tion; and the necessity of a preface would be done away with, much to the author's relief, were it not that here, if anywhere, acknowledgments may be made. Three of the following essays have appeared in Lippincott's Magazine, and are here reproduced by kind permission of the publishers of that periodical. Here and there throughout the volume are paragraphs that have seen the light before, but these preliminary items were but the nuclei about which have since clustered what I hope will prove to be profitable reflections readably 'expressed.

C. C. A.

Trenton, N. J., April I2, I896. 



\section{Contents}

Notes of the Night $\ldots \ldots \ldots \ldots \ldots \ldots \ldots$, I

When Grass is Green.................... 79

Out of the Beaten Path $\ldots \ldots \ldots \ldots \ldots \ldots$ I 47

An Old Barn $\ldots \ldots \ldots \ldots \ldots \ldots \ldots \ldots \ldots \ldots, 155$

A Rocky Roadside $\ldots \ldots \ldots \ldots \ldots \ldots \ldots \ldots, \mathbf{1} 65$

Up Pearson's Lane..................... I8I

A Yule-tide Ramble...................... 194

LANDMARKS. . . . . . . . . . . . . . . . . 206

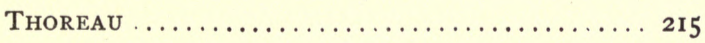

$\operatorname{INDEX} \ldots \ldots \ldots \ldots \ldots \ldots \ldots \ldots \ldots \ldots \ldots, 227$ 

Whotes of the Might 



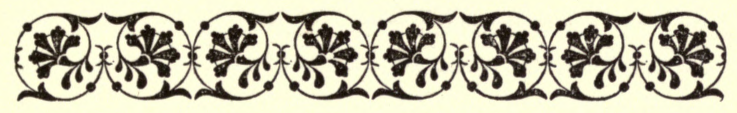

\section{Nhotes of the rigight}

$\mathrm{T}^{\mathrm{T}}$ is the purpose of Nature that man shall labor while it is day, and then rest; but the contrary is true of many millions of living creatures. These nocturnal toilers are not curious, in a human sense, as to man's doings, though influenced by them; but some of us are curious as to their ways, and so it is not strange that the question is often asked: What of the night?

Let us first ask: What is night? As treated in the following pages, it is that portion of every twenty-four hours when we are without direct sunlight. Its birth is the gloaming or twilight; its maturity, darkness; its death, the dawn.

In the city these conditions are not so well marked, but beyond the town's limits, Nature still rules, and he who is curious in such matters finds the twilight the beginning of a day of new activities, in which he may take no part, but of which he may be a spectator.

To the novice, it is a trying experience to distinguish objects in the twilight. The more or less 


\section{Whotes of the Whigbt}

indefinite outline of everything makes the observer painfully uncertain, and, strange to say, fixed objects frequently appear to move, and even to approach the beholder. Hence a deal of this world's superstition. If cedar-trees would but cease to dance in the gloaming, and vine-clad fence-posts remain where they belong, the number of ghosts would be materially lessened. Often have I waited for a small juniper or slender cedar to come up to me; and while I stood in this uncertain mood the thought arose, What manner of man may this prove to be? - which is no pleasant train of thought when alone in the wilderness.

Twilight magnifies; and the low bushes that sparsely dot a neglected pasture spread out and out until the open country becomes a forest. How very quickly, too, every such scene changes when the wind carries with it a veil of cloud. The dusky landscape passes out of sight. With the fading light temporarily shut out, near objects withdraw, leaving a lengthening void. This tricky feature of twilight is most pronounced when clouds obscure the moon, and suddenly pass by. The wave of darkness and flood of pallid light in quick succession put the world in motion, and nothing, even to the hills themselves, is fixed. Often, too, a brief, weird change comes without any intimation of its approach, when the dim light is fast fading, and we are on the threshold of night. A pyramid of pale light flickers in the northwest. Its apex 
may be low down, and the base spread well along the horizon; or it may be narrow, with the apex nearly overhead, and so quite like an aurora. This is the zodiacal light, a glow, it is said, "from clouds of meteoric matter revolving around the sun." It is, whatever its true character, a matter of uncertainty as a twilight phenomenon, and seldom does it re-light the landscape except for a brief moment. The world again dimly stands out, while it lasts, and then - the darkness of the night.

These are matters of the universe and our little world plays a pitifully small part in them; but, if our learned men are not wrong, a strictly local disturbance may affect the twilights of regions thousands of miles away. It is a miserable plan to cry "coincidence" because an explanation seems to us improbable, and a great deal of ignorance is due to our obstinacy. In August, 1883, there was a terrible volcanic outburst at Krakatua; an island was destroyed and great local disturbance caused. Here, in the valley of the Delaware, two months later, and from that time until the early spring of $\mathrm{r} 884$, we were favored with from three to seven beautiful rosy twilights every week, and an afterglow that lingered for hours, with a ruddy tinge over the western sky and a bright green eastern horizon. There would be some variation from this, at times, but not often, if we except sudden flashes of ruddy light, that sug- 


\section{Wotes of the Naigbt}

gested a nearby conflagration. The entire autumn was thus signalized; but not until the first week in January, more than four months after the disaster in the South Pacific, was the climax reached. Often the night was more beautiful, if less brilliant, than the sunny day. We had no red snow, but rosy fields and great, white, staring stars, that in the green sky had a frightened look.

These strange twilights and pale nights were due, it is said, to the dust thrown into space and floating around the earth. There is no reason to doubt this, and while we want no volcanoes to blot out islands and sweep men by thousands into eternity, we will welcome the dust they raise, if raised beyond our atmosphere. This part of the world is not particularly blessed; it needs all the rosy tints that it can get.

My best remembered walk, those winter nights, was early in January, 1884. The blackness of night was overhead, but its gloom was dispelled by the brightness of many stars. In the west, all was rosy, and the east claimed equal splendor, with its brilliant green. The fringe of the black curtain did not reach the earth, but moved with me as I walked, ever directly above, always threatening to enwrap the world, but held back until after midnight by the glowing glories of the horizon. It was indeed a most strange time; and it bewildered every bird of the day as greatly as it did the night-wandering owls. Wild life was all 
awake. The drowsy tree-sparrows gathered in the dark cedars of the old worm-fence twittered as if in doubt whether or not they should again be stirring, and from the distant wood rose the sleepy cries of many birds, disturbed but not awake. The brittle skeletons of the dead summer grass trembled as mice hurried by them, and the lispy squeaking of these little travelers, when I blocked their paths, sounded clear and full as the cry of their arch-enemy, the hawk. I know not why it is, but every sound heard during a still, cold winter night has far greater volume than the same sound heard by day. That you are guided as much by hearing as by sight may be reason for this; for how often we can hear approaching footsteps, crunching the crisp snow, long before we see the person approaching. So, too, in the fields, by placing the ear close to the surface of the snow, or even on the bare ground, we can detect sounds that could not be heard at mid-day. By a little training our sense of hearing can be taught to locate life that is hidden from us, as the woodpecker hears the grub that nestles beneath the bark of a tree. The sounds at night, in midwinter, may not be many, but not one is lost to us. The untaxed air gives every utterance full play, and what at other times would be unnoticed comes to us in full measure. Unfortunately, coming sometimes without knowledge of its origin, the imagination is wrought to such a pitch that curi- 
osity often gives place to fear. Then the nightwanderer wishes himself at home. The timid naturalist has not chosen his vocation wisely.

This night I kept to the highway, with a catowl almost at my elbow. It was excellent company, though it laughed, I fancied, when I stumbled over the frozen ground, for the path was in shadow and my eyes kept only the painted skies in view. Whether it so happened that we both were eastward bound, or the owl sought me out as an ultimate victim, I do not know, but the association was too marked to pass unnoticed. The bird kept an even pace, flying almost as slowly as I walked, and resting on each wayside cedar until I came up, never a matter of more than a dozen paces. Would it turn down the lane, I thought, as I neared the gate. The big red oak there might stay its progress, and a mouse in the field call it off; but no, the lane was no bar to its pupose, and I saw the owl constantly before me until I reached the house. A petrel will follow a ship for days together, and with good reason for this; but why should an owl follow a man? Could the fur gloves that I wore have been the attraction? I can think of nothing else. Later I was told my owl meant good luck, but how soon after-ten years have now slipped by in this case - my informant could not say. "It 's sure though," he insisted, as if he had often been a recipient of owl-presaged good fortune. I was led, 
this same evening, to see how far this bird of the night figured in local folk-lore, but the old graybeard that I interviewed could tell me nothing more than I have mentioned. Ignorant and superstitious as he was, he told me a rambling story of how an owl might have been the ghost of an old farm-house, but was not. It ran thus: Many years ago, there was a cold rain-storm in June, and for comfort a fire was built on the open hearth instead of in the air-tight stove that stood before it. All went well until the night was well advanced, when a struggle was heard and suppressed cries, and after a brief silence, a shuffling of feet, as if at the doorstep. The men went out with a lantern, but no one was to be seen. The windows were then searched, but there was nobody near them. The older folks were becoming unsettled. The matter was discussed in whispers. Again and again the noises were heard, and, at last, when everybody was roused to a high pitch of excitement, the long stovepipe, heated by the flames upon the hearth, parted at a joint, and out flew a sooty and bedraggled little owl. No one was superstitious then; but suppose the owl had made its way back to the chimney, and by that way escaped; would not every person present have had vague, uncanny feelings? Would not the house from that time have been haunted? "Folks may be right, but when I hear o' ghosts and such like, somehow I call up always that little 
screech-owl, and wonder if they could n't 'a' found one somewhere, if they ' $d$ 'a' looked a little further." This sounded strangely, coming from the lips of an old man who honestly believed in luck and the asserted signs thereof; but then, ignorant or educated, who among us is consistent?

But not all winter nights are tinted with volcanic dust, and what of those of more commonplace character - of those, for instance, when the full moon is shining on miles of snow-clad fields? It is not always attractive. There is a ghostliness about it suggesting the pallid remains of a sunshiny day. This is the more true when we can see but the bare landscape and hear nothing; but the whim vanishes when some night-prowling animal passes by, or we see the shadow of a wandering owl. If there are trees near by, we may be startled by the flying squirrel; and look more closely about us if we hear the crisp rattle of the yielding snow-crust, and see half-a-dozen whitefooted vesper mice go scampering across the wide expanse. These creatures look twice their size at such a time, and with what a thrill do we watch the race if a weasel is in pursuit of them. Remember, too, that moonlight keeps many a bird awake, and so we should be on the lookout for such birds as are probably to be seen in the same place by day. I have known a whole colony of white-throated sparrows to twitter at midnight, and even to fly out from the green-brier thicket 


\section{Thotes of the thigbt}

that all the season had been their home, making short journeys into the open country as if curious to know whether or not it was really day, and could not determine. The horned larks, that keep so closely to the weedy fields before snow comes, are not driven off when their feeding grounds are covered, but go seed-hunting where the tall weeds stand above the snow, and trip gaily over the smooth-backed drifts or level reaches, where nothing they can eat is found. Can it be they can dine upon snow-fleas? These same larks will sometimes be active at night when the moon is full, and, for some reason unknown to me, look black as crows. Indeed, all creatures, whatever their colors, show no variation in this respect unless you are very near them, which seldom happens.

I remember walking over a snow-clad meadow late at night when the only light to guide me came from the innumerable stars. These were all imaged in the glassy surface upon which I trod, but not an object was plainly seen. The bushes were vague in outline, and every tree appeared much taller than by day - so much taller, indeed, that I could realize the fabulous dimensions of the Pacific coast pines that John Muir so graphically describes. The long line of sassafras trees that skirted a marshy meadow, the scattered shellbark hickories, and one lone liquidambar are but fifty or sixty feet high at most; but then, in the 


\section{Hotes of the Night}

starlight, and what I may call the snow-light, they towered a full two hundred. I had been reading that day Muir's volume, and the mountains of California seemed to have settled on the Jersey meadows.

Fortunately we do not need the eyes of an owl to see in comparative darkness. The image may be obscured, but our senses are so alert that sight is aided, and we have a lively appreciation of what happens. This, at least, is true when we deliberately set out to study the night-side of nature, but not so true when the element of fear enters into the question. If it is not overcome, the world after dark must remain a terra incognita, and accepted at second-hand. I am not sure that it is ever completely overcome, and so thoroughly cool and collected study of the natural history of night may be impracticable. People, of course, resent being called cowards, but when, walking alone on an unfrequented meadow, and at dead of night, the wind happens to gather up a hundred dead leaves and sends them after you with a great noise, you are not disposed to observe them hurry by without wishing you were sure of their identity as dead leaves. Every inanimate object seems more than ordinarily alive and charged with some uncanny message. Draw a distinction between being startled and frightened if you will, but, whichever it may be, in every case it robs night rambling of some portion of its charm. 
The attempt to banish timidity by having a companion is never a success. We may see no reason why wild life should resent the presence of two and not object to that of one person, but this, in my experience, seems to be true. Certainly there is twice the noise; an overpowering desire to talk; a doubling in fact of every possible objection. To my mind a successful stroll must be taken alone. Fewer night-prowling animals will crouch in the darker corners while you pass by, if they have but yourself to watch and guard against.

But to my walk: I had not proceeded far when an animal as large as a domestic cat appeared to cross my path. I stopped for a moment, and then another came in view. Not seeing distinctly the direction from which they came, I moved slowly forward, and saw still another of these black creatures cross the road. Were they dogs on a still hunt? I did not dare admit to myself that I wished myself away; and, taking a few steps forward, I saw that there was a long procession of these supposed animals, not moving, but fixed as the hills beyond them. They were the tops of fence-posts projecting above the snow. Had I turned back, which was my first impulse, I could have sworn I had seen several animals moving over the snow. So much for the tricks darkness plays with half-timid humanity.

It occasionally happens that suddenly, without 
a shadow of warning, the darkness is dissipated by waves of colored light, the stars grow pale, and day, without daylight, returns. This is the aurora - a meteoric phenomenon of such magnitude that we can not only see it but hear it. We are told that now the magnetic needle is disturbed, and we have noticed how the bright flashes and strange rustling like a silken garment have twisted weak minds out of sane paths. I have witnessed hundreds of auroras and noted their peculiarities, but not one, for general interest, equaled, that of March 30, I894. It would be mere folly to attempt a description. There was much color, some crackling noise, and a flickering light on the earth's surface about equal to that of the moon when full. The center of illumination continually shifted, and once my companion remarked: "See, Orion is taking an electric bath." Curious to ascertain what, if any, impression such an occurrence would have upon animal life, I hurried to the nearest available point, a long reach of the river shore, where the stream was wide and the banks well wooded. The birds were all awake, and I heard one song sparrow sing its full song, while a whole host of small birds twittered excitedly in the evergreens. Fortunately there was no moon, and as the aurora came and went with startling abruptness, the agitation was more marked among these roosting birds than would have been caused by a steady 
light. It was really affecting to hear the faint chirping as darkness spread over the scene and the birds settled again to rest, only to be again disturbed and frightened by darting and rattling tongues of colored light, yellow, blue, pink, and green. It was to me a curious rather than beautiful sight. It was unnatural, disturbing, and out of place: the clatter and clash of machinery when some important part is broken. The effect of alternating light and darkness upon the river was more marked than upon the land, and one brief interval was so wild and weird that I shall never forget it. I stood upon a broad stone that the incoming tide was slowly covering, and heard in the darkness the sobbing of little waves that broke at my feet, and when some larger ripple, tipped with starlight, broke over the stone, it seemed as charged with the auroral light as the cloud-flecked sky had been but a moment before. Then followed silence and darkness, out of which came strange cries that I did not recognize, so great was my surprise. As I listened, the aurora returned with all its vividness and illuminating power. The river, and even the opposite shore, could be seen, and directly in front of me three great blue herons were slowly flying up-stream, and the air all about them was filled with bewildered killdees. The long dark bodies of the herons and silvery glisten of the plover stood out with marvelous distinctness while they re- 
mained in sight, and the clear call of the smaller birds, when again plunged in darkness they wandered they knew not where, sounded as strangely, as un-birdlike and despairing as the whispering of the hollow wind. As it neared midnight, the aurora lost its brilliancy, and the chilly air, for it was March and the sting of winter not yet drawn, suggested shelter. Mere repetition would not have proved more suggestive. It is possible to look too long at one object. We can cloy the brain as readily as the palate.

Much might be said of night-flying birds. We know that migration occurs largely between sunset and sunrise; but I refer to the effect of such an occurrence as this aurora and, to a much more limited extent, the effect of local fires. No barn or haystack ever burned at night but it brought the roosting birds about it; and hundreds, bewildered by the flames and heat, plunged headlong to destruction. I recall one instance where a flock of redwinged blackbirds rose as one body from a neighboring meadow and, after approaching the fire, endeavored to pass over it. They did not rise far enough, and, when directly over the burning building, rained down upon it. It was the most complete work of destruction that I ever saw. It is well known how fatal to migrating birds are the lighthouses along our coast, but not even here is as much life destroyed as during the great forest fires that sweep over hundreds of 


\section{Motes of the Might}

acres of woodland. Bird life has certainly a hard time of it these latter days. But there is a pleasant phase of this subject wherein death plays no part. It is something to be serenaded when sitting at your camp-fire, after supper, while smoking a contemplative pipe. But let me go back a few hours. All day long, my companion and I had tramped over

Meadows trim, with daisies pied;

Shallow brooks and rivers wide;

or, to be more exact, had tramped until we reached the river. Just before sunset, we walked to the headquarters of the farm upon which we had been squatting. It was well we did. Not that we had any unlooked-for score to settle, but because we had a delightful opportunity to indulge in antiquarian research. Prehistoric archæology had been the serious business of the day, but now we were playing. What we are so little apt to find in most localities occurred here in abundancethe original house with its original furnishings: a quaint house, built of hewn logs and chinked with stone and snow-white mortar; or shall I not say, a huge fireplace with a small house surrounding it? This fireplace measured six feet in width, five feet to the base of the mantel-shelf, and was three feet deep. The chimney-throat was two and one-half feet by one and a half, and the chim- 
ney itself twenty-five feet high. It is useless for architects to tell us a big fireplace will not fit a small room. Let those who think so come here and see this glorious structure.

Since the day of the settling of this farm, just two centuries ago, the changes of ownership have been only from father to son, and such a strange accumulation of personal effects as we found scattered about! New tools had gradually replaced old ones, but the latter had been preserved, so that the evolution of many a utensil could have been traced. Then, too, there were domestic fossils, as the spinning-wheel and many a tool for the preparation of flax. Here was a colonial museum and a dwelling combined. A sewingmachine and grandfather's clock, side by side, and a "rocker" that was the comfort of the greatgrandmother still a comfort to child of the fourth or fifth generation.

We passed from such pleasant surroundings to the site of an old Indian village on the river bank. Possibly to many such a spot may be a soulsickening solitude, and, indeed, a wilderness of Jamestown weed, thistles, and nettles scarcely commands our admiration; but the Indians had been here, and the river remained as in the days of their glory, and this meant much to us. Betimes the camp-fire was alight, and the single sound that we heard was the ripple of the river but a few yards away. The sobering silence of 
the night was the subject of our conversation at the time; when suddenly a sad, sweet song broke the very stillness that we deplored. A vesper sparrow-most appropriate bird-roused by the light our fire shed about it, came even nearer to us than it had been, joined the fireside circle as it were, and sang in a most exquisite mannersang as if dreaming another happy day had come.

It is not strange that we slept well afterwards; it is something to have "good-night" said to us in such a manner. Nor was it strange we awoke at sunrise with senses all alert. Earth and the sun counseled to picnic on the river, and we were fortunate to be guests on such an occasion. There is wealth in every moment of such a time. Nothing was missed. No imperfection blighted objects at hand or marred the landscape that hemmed us in. A smoke-gray mist followed the river as it hurried by ; the outermost hills were veiled in filmy cloud. The near-shore pebbles were black, shining, and dew-coated; others dull-gray and making a curious line that puzzled us until we noticed that the dry ones were protected by the overhanging trees.

For a time - never satisfied - I missed the singing of the early summer birds - it was now September - but the early hours are fittest for silence. The impression of peace, of rest after labor performed, was that which made me congratulate myself that I had happened here.

Perhaps it was that the cunning birds were only 


\section{Ninotes of the Nifigbt}

waiting until this whim of mine might have fair play, for when the sun rose well above the hill and flooded with cheering but not fiery light the river, the hill-slopes, and the mountains far beyond, then the birds welcomed the glorious autumn morning in no uncertain tones. Jays, woodpeckers, king-fisher, heron, hawk, and crow. "What a chorus!" I hear shouted derisively. But, deluded summer-day mortals, there was that in the united voices of these birds that alone could meet the requirements the conditions demanded. It was sound that excited the heart to stronger beating; sound that thrilled us; that raised us above the level of low-lying clods; that transported us to the mountain's top; even lifted us above the clouds and made us one with nature in her exalted mood. Mere sound, if you will, but with wellnigh every merit music can claim; and, happily, sound that comes back at call, so that for a brief space, even in the stuffy town, we may live over again life's choicest moments.

The thrush and summer's dream-life are closely linked; the scream of the falcon and an autumn sunrise are the battle-cry and banner of more active days. Melody and meditation - these fit well with summer-tide and restful night, and, as such, count for much; but the daybreak, with its defiant shout and irrepressible energy,-it is well for the world they count for more.

We naturally associate the owls with night, and 18 
to a far greater extent than the facts allow. Some of them are strictly diurnal, and not one but requires more light than is common to an ordinary starlit evening; on the other hand, while the birds of the day generally go to their roosts soon after sunset, some of them are quite active during and even after the gloaming. Opportunity favoring, I carefully watched the birds of an orchard and wooded hillside during an entire summer, and was surprised at the number that were active after the light had so far faded that I could only distinguish the species when they were clearly outlined upon the western sky. Though the robins kept chirping long after they had settled for the night, they did not appear to move about voluntarily, and the last bird to give up food-hunting was the woodpeewee. How it could detect insects in the dim light is a puzzle to me; yet it darted from its perch, flew with the same confidence, and snapped its beak as suggestively when I could scarcely see the bird as it did in the blazing noontide of a midsummer day. Night after night I watched this same bird, and in no instance found it outstayed by any other. To my surprise the red-start and Maryland yellow-throat were close seconds. A red-start had its nest in a cedar-tree in my yard. I found the birds when the nest was first begun, and saw them daily until the young had left it. These active little fly-catchers did not cease hunting until the last glimmer of rosy light had faded 


\section{Whotes of the Nifigbt}

from the sky. Although early risers, as all birds are, the yellow-billed cuckoos were no advocates of the maxim "Early to bed." I could detect them flying across an open space over a brook when it was quite dark, and the pair that had a nest with eggs, which I found on August 28, frequently left the orchard for more open ground at quite a late hour. There seemed too little light over the fields for successful hunting, and the orchard itself was very dark; too dark, it would seem, for them ever to find their way home.

How late the chimney-swifts are abroad I cannot determine. Long after I failed to detect any in the air, I could hear them in my chimney. It was the same rustling sound heard by day when I could see them coming and going, and I. know that these birds were leaving and returning when the night was very dark. I think they can be classed among the nocturnal species.

The dim light of early evening plays havoc with one's patience, at times. Often, as I roam the open fields when night is closing in, I can distinctly hear the herons, plover, and, sometimes, a flock of red-wings. I know that they are flying overhead, and yet it is only on the rarest occasions that I can catch a glimpse of them. It would seem as if so large a bird as the nightheron could be made out even against a star-lit sky, but such is not the case. It is not difficult to locate the sound; you hear it as the bird ap- 
proaches, when it is directly overhead, and as it passes away from you. You strain your eyes in the proper direction, as you believe, yet there is nothing to be seen, or not in one case in, perhaps, a hundred. Has the damp night air to do with the traveling of sound? Is the bird somewhere else? Or is it at so great an altitude that even by day it would be inconspicuous?

There are two common birds with us that occasionally fly at night, and in such a manner as to fairly frighten the unthinking rambler. These are the dove and quail. I have usually noticed them at such times in pairs. The rapidity of their flight is incredible. In one instance, I was stooping over a large moth that I had caught with my hat, and just as I was about to rise, a sound like the hiss of a bullet sent me back to my knees, but not before I saw the doves dart by me. I plainly felt the wind of their wings, and had they struck me, I believe I should have been injured by the blow. Quails, in the same mad way, go rushing by; and if, at such speed, they can deflect from a straight course and avoid obstacles, it is one of the great wonders of the flight of birds. Occasionally fatal collisions do occur. I have found dead birds with their heads crushed to a shapeless mass, and have known even the active swallow to be injured by a telegraph wire.

Birds sleep lightly. It needs but the slightest noise or movement to rouse them, and their $2^{*}$ 


\section{Whotes of the Might}

senses are at once alert. Danger from their nightprowling enemies is the reason for this, and yet they are really quite helpless if the night be dark. Lightly as slumber rests upon them, many are given to dreaming, and those that sing by day repeat their songs at intervals after dark, but in a drowsy, half-hearted way. This singing was a very noticeable feature of a recent stroll over weedy meadows to the creek-side. The last heron had passed to the thicket where many were nesting, unless they were going and coming all night, and even the ghostly chat had quit muttering, when suddenly a Carolina wren startled the still night by a ringing song that usually is heard at daybreak or later, and it was now midnight. The crested tit took up the cry, and sounded an alarm from his perch in a tall tulip tree; then the rose-breasted grosbeaks sang as they only can, and sparrows in the briers trilled dreamily.

There was no day-time vigor in all this, but a drowsy languor that fitted the time if not the place. And yet, for the moment, I forgot that it was night. Hearing these dulled voices, my own senses were made more alert than before. The doubt that is so prominent when one rambles in the dark turned to confidence, and I seemed fitted for any activity. I looked about for owls and listened for their hooting, but not one put in an appearance. The meadow mice might have held 
high carnival in perfect safety. And this recalls a little tragedy that occurred at the time. Mice, at that moment, were moving in the grass, and presently I heard the faint patter of little feet where a windrow of dead leaves had gathered. I stood perfectly still. There was nothing lifelike to be seen, but the sound was distinct, and then how promptly imagination provides all the rest! I waited for perhaps a minute - it seemed many - and then a moving figure came nearer and nearer, until I recognized that dainty creature, a white-footed deer mouse. Intent upon its own quest, it paid no attention to me, until within reach, when I slowly extended one hand, when it sat up like a little kangaroo, gave a shrill squeak, and was off in an instant. I could not hear its retreating footsteps, but a moment later there was a cry of despair, followed by a death-like silence. It was the ever-recurring tragedy re-enacted. The mouse had run into the clutches of a weasel, and its little life was snuffed out. The question rose, would the weasel appear? Not a bit of it. That creature has had too long experience not to know a man, even without seeing him.

But how did I know it was a weasel that caught the wood-mouse? I do not know it, and yet feel confident that I am right. I do know that the weasel is one of their principal enemies, and that is a justification for speaking without special reserve. It might be a skunk - which is 


\section{Whotes of the Nitigbt}

a species of weasel — or a mink, another of the same family; but bother the particulars!

Passing on to the bank of Poaetquissings Creek I had an opportunity for more positive observations. There was more light. Every star was doubled in the broad expanse of quiet water, and the noses of fishes pushed just above the surface could be plainly followed. I sat down on the dewy grass, and watched the water and the outlines of the overhanging elms that were sharply drawn against the western sky. I wondered that the daylight should linger so long, when I suddenly recalled the time, and the cause too came to me. There was an aurora. Shifting pillars of pale green light shot upward, and rosy-tinted clouds were directly overhead - as suddenly it became dark. It was one of my lucky moments to be here at such a time. This strange phenomenon had its effect upon the birds. With every flash of light many were suddenly aroused and sang as they started from their sleep. With the return to darkness came silence.

Incidents like these, with far less of adventure than the usual occurrences of the day, are sure to be remembered. Because they happen at night they make deeper impressions. This is explained by the fact that our attention is concentrated upon fewer objects and a more limited area; moreover, the experience smacks of novelty. This night the aurora continued to increase in 
brilliancy and steadiness, and the day seemed to have returned. I could distinguish the different forms of leaves in the trees about me, and peered among the branches for the owls that belong to night. It was all in vain, and I took it as a warning when a huge bull frog at my feet muttered GO-O HO-OME. I started while I could plainly see my path, but in a moment it was dark as Egypt, and in the silence of night I groped my way to the garden gate, while my neighbors were yet resting.

There is little to be said of absolute darkness. It is one of the rarest conditions of night, and I have only known it as one of short duration. A densely clouded sky and the absence of the moon are the requirements of this condition. When abroad at such a time, I have usually noticed a faint wave of light, as if from reflected lightning. It comes and goes with marked uncertainty, but never is stationary. I have fancied that it might be the ghost of that ghostly phenomenon, a will-o'-the-wisp, an ignis fatuus dissolved in the damp air of night. This wave of light rarely does more than faintly outline the tree-tops, and so does not reach to the ground. It is a time when our path must be felt; but the sense of touch becomes very acute, and as the outstretched hands come in contact with familiar objects, it is remarkable what pictures are before the mind. We touch a fence-rail, and immediately the fence and all its surroundings are distinctly before us. 


\section{Nhotes of the linigbt}

The foot mechanically recognizes a slight sloping of the ground, but the brain interprets the full meaning of the conditions, and we know that the brook is not far away, and we listen for the sound of flowing water. Of course, we must be in some familiar locality. It is madness to ramble in a strange place in absolute darkness. When such a necessity occurs, the realization of danger is so intense that the senses are paralyzed rather than quickened. But mistakes sometimes happen even when we know the ground. The most trivial incident at the outset may set at fault our orientation, and with great confidence we move along in a direction opposite to that which we proposed to take. The result is readily foreseen. When we expect to find ourselves at a given point, as at the margin of an open meadow, we suddenly find ourselves in collision with a tree. Then a condition of bewilderment ensues that nothing but light can remove. Striking a match, it is probable that we can discover our position, and, with regained confidence, retrace our steps. It is very seldom so dark, however, that such expeditions are practicable, and under the most favorable circumstances there is too little to be gained to warrant running the unavoidable risks incident to positive absence of light. We are groping in the dark much of our lives, but in another sense, and let this suffice for the literal one to which I have referred. 


\section{Whotes of the Whigbt}

But the blacker the night, the more favorable to witness that strangest of all nocturnal phenomena, the will-o'-the-wisp. I have seen it but seldom, and possibly some records thereof in my notebooks may be erroneous, the glimpse of flickering light being attributable to other causes. But in one instance there was no mistake. The day had been extremely warm and sultry, the hygrometer registering $88^{\circ}$. As the night promised to be favorable, I started for a swampy thicket that I might "sugar" moths. Provided with a lantern, to be hung on a tree, and the various engines of destruction required to capture the huge night-flying moths, I was equipped for business rather than pleasure, and gave attention only to the foot-path, seeing nothing beyond its boundaries and hearing nothing but the din of frogs. The over-arching trees shut out the sky, and I knew nothing of the storm that was rapidly approaching. Mere darkness has no influence on batrachian life, but the rising wind and electrical conditions that I did not notice were evident to them, and soon every one was silent. Then I found myself enveloped in absolute darkness, except where the few feeble rays from the lantern fell at my feet. I hesitated whether to proceed, and stood for a moment by a giant tulip tree to consider the matter. As I did so, a great gust of wind and misty rain passed over me, and a toad at my feet gave a loud despairing cry, as if it were the last living creature on earth, and cre- 


\section{Thotes of the Ninigbt}

ation were on the verge of chaos. Here, at last, I had found superlative wildness. I could not have imagined anything more unlike the living day, and yet there was something more in store for me. Just beyond me, where a spring struggled with little success to break through the sphagnum and form a little pool where skunk-cabbage grew rank as a tropical jungle, and all was hedged in by briers that nothing larger than a weasel could penetrate-here, suddenly, a shapeless, flickering flame appeared, disappeared, and reappeared, fitfull as an auroral light, but far more weird, unearthly, and repellent. The motion was, in a way, lifelike, and the light itself shed no radiance upon the surrounding objects. It did not retire as I approached, but faded quite away and only came again into view as I backed from the spot to my original position. How my presence could affect it puzzled me, and I forced my way again as near as the briers would permit, and waited for the reappearance of the light. It seemed a long time, as I was standing in an uncomfortable position and of course impatient; but at last I could faintly detect a trace of luminosity near the ground, but no outlined area, like a sunlit cloud. By my mere presence I seemed to hold it down; to keep this wild dancing imp of the dismal swamp under control. But a moment ago, free as the air and active as the wind, and now groveling on the weedy 
ground. How completely all sense of loneliness disappeared. Here was excellent company. Will-o'-the-wisp, though rather abject at present, was really a good fellow, as it proved. Tired of playing the tyrant, I withdrew and, resuming my stand under the tulip-tree, awaited developments. At this distance I could exert no influence, and again the light appeared. Not a tangible, measurable light, but merely a fragment of the darkness made visible. Darkness quickened and so overjoyed with its life that it danced. Then the gathering storm broke over me, and Will-o'-thewisp disappeared.

I can trace no forms of light intermediate between this and that which is emitted by the masses of dead wood that are more frequently found charged with phosphorescence. The effect is very different. The latter shows at once what it is, and while interesting and likely to command attention, is as prosy and commonplace as the ignis fatuus is poetical. It frequently happens, when there is a high summer freshet in the river, that phosphorescent wood comes floating down stream, and, if the night be dark, it appears to set the water on fire. It certainly comes much nearer to it than do any of the inhabitants that dwell along shore. When floating, phosphorescent wood gives out a brighter glow than when, as decaying wood, we come across it in a swamp; but in this latter position it may present an appearance that is positively star- 


\section{Thotes of the Naigbt}

tling. I once found the trunk of a tree that had been prone for half a century, and it was not only all aglow, when the night was dark, but the outlines of a burrowing beetle and grubs could be plainly seen. The glimmer had no impression on the outside world. All was dark even at the very edge of the wood. It was like looking in at a window of an illuminated house. I saw this same decaying tree-trunk many times afterward, but there was no trace of phosphorescence.

Very different are such local illuminings of the solitary swamps from that sparkle and momentary glow that we first see during the last week in May. Here and there a single flash, and then darkness deeper than before. As the weeks roll by, more and more, until thousands of the light-bearing imps are abroad, and the low-lying marshes fairly dazzle with their efforts to replace the sun. Conditions must be favorable for large gatherings of these insects; but when they are collected in some limited area, and no disturbing wind breaks their ranks, the pyrotechnic display is simply marvelous. Comparatively few people, it would appear, have seen the fire-flies at their best, although familiar with them all their lives. They have seen a dozen or more flash at once, it may be, and chased, when children, single flies, to place under a tumbler, but know nothing of secluded corners in brush-grown meadows where a thousand are flashing together and, by their united efforts, casting light over all 
their surroundings. The bushes appear tipped with fire, but it is not fire nor even a heat-giving light. The purport of this strange phenomenon is not altogether clear to us. Every entomology has much to say, but it is a glittering generality, much like the light itself, and when done reading we are about as much in the dark as when the flash of a fire-fly is suddenly snuffed out. I know these insects as fire-flies, and nothing more. "Lightningbugs " in boyhood days, and it is a better name, if not quite so elegant. We are well favored here at home with these beetles, for there is the yellow flash-light on the upland fields, and a blue light on the meadows, the latter appearing to leave a long thread of light behind it as it flies. I have occasionally seen them, single ones, above trees that were sixty to seventy feet high, and timed the duration of their light at one and three-fourths seconds. Bats, it may be remarked, swallow them greedily, but I do not think the wood-peewee ventures to molest them; at least not after sunset, when the light is distinct. Would a bat, whippoorwill or chimney-swift become phosphorescent after an exclusive meal of lightning-bugs? The light, when rubbed upon the fingers, leaves a glow that remains for a short time.

I have seldom noticed "glow-worms," or firefly larva, near home, although I have searched the meadows carefully; but about Princeton, some ten miles away, they are not uncommon. They 
cast but little light as they crawled through the grass, and might readily be overlooked by the unobservant pedestrian. Placed under a tumbler, the same number of glow-worms gave about half the amount of light thrown out by the common flashlight fire-fly. The toad ate them, I noticed, but did not illuminate his viscera by so doing.

Night would indeed be a season of darkness did it depend upon insects for illumination. Even the stars, with not a cloud to veil their glory, give little light, and so the moon is its real dependence; and what more can be said of moonlight? It figures in all poetry, and is prominent in all prose. It has been sung until our ears are weary; it is the burden of many a bright essay and learned dissertation. It is the most familiar of all conditions of nature, except sunlight and rain. It is so thoroughly known from every point of view that he is overbold who more than incidentally refers to it. And yet so full has been many a midnight ramble when the moon shone at its best, and so suggestive many an hour when floating on pond or river, guided solely by its light, that I cannot pass by these times in silence. Very different is this same moonlight on the land and on water; and to realize this, it is well to walk for miles over the meadows or fields and then, coming suddenly to the water's edge, take a boat and float aimlessly about. Though you may have been familiar with the locality by day for all your life, it is another 


\section{Mrotes of the Maigbt}

world now. Go out into the night with no disturbing thoughts. Gaze awhile at the stars and lose in a measure your earthiness, and the song of a dreaming bird will arouse you to a quicker sympathy with the creatures to which it is now day. And, above all else, do not go out into the night if you have been abroad all day, and so, from sheer exhaustion, are not in a receptive frame of mind. Few things in this world are more marked than the limits of our endurance. Varied as are the aspects of any landscape during the four seasons, it does not make material difference when you go. There will be far more open to you than will be seen, and even in the dead of winter it will not be a case of "silence for all sound." Though the world at such a time may seem asleep, some creature other than yourself will surely be astir. It remains with you whether or not you see and hear it. I have often taken such a walk as this, both during the harvest-moon at the end of summer and when the same moon flooded the landscape in January, with snow and ice for withered weeds and open water.

Under the old oaks, whose leaves, because of the drought, were now tough, leathery, and limp upon their stems, the moonlight failed to light the well-worn path, but as I looked upward, the treetops stood out upon a blue-black sky, and the twist of every sturdy bough was plain as day. But how much larger! This is one of the charms 
of moonlight. We see the world as through a magnifying glass; and the end of the path, whereat we pass into an open field, it, too, was very far away. Shorten your steps now, and a long journey is before you, though the real distance is as nothing. What strange figures we see where the groups of leaves are edged by the silvery light! There is scarcely a familiar face but you see here the profile; and many the moping owls, crouching cats, listening squirrels, and roosting buzzards we detect as we pass from under one tree to another. It is little wonder that savage men are superstitious; for not only, in imagination, is every known creature sporting in the moonlight, but those that are fancy's creation also lurk in the leafy branches. At times these appearances are so real that no arguing with one's self will prevent our pausing and waiting until the passing breeze rearranges the leaves and the monster disappears. This may not seem an enjoyable experience; perhaps it is not; but surely such a thorn in our side should not deter us from a moonlight ramble. As the time passes, confidence returns, curiosity is aroused, and we forget the fear, if it was really such, that at first possessed us. Unless too noisy, and silly enough to whistle that our courage may not be lacking, real life will soon assert itself; for there is an abundance of it in every woodland tract. It may be a squirrel that stirs upon some branch, or the owl that shifts his position that it may better 
watch you; but whatever the creature, the surroundings set it in a new light to you. If only day-time acquaintances before, they are strangers now. Unless constantly on guard, you will very fancifully interpret everything you see.

When the moon is higher in the heavens, and the shadows short and crisp, the woods are more real to you, and the distorted images lurk only in the underbrush. Then look for startling effects, when the dusty cobwebs float before you. It is fortunate if you have not anticipated these, for there is much in store for you, and an hour will slip by before you suspect how late it is growing, while you try to determine what this is that blocks your way, or stands guard to seize you if you dare to pass it. One dew-spangled web, glittering, and moving to and fro in bright moonlight, I finally determined was my neighbor's cow, and so drew near. How glad I was to be alone when I made the discovery that awaited me. It is never pleasant to be called a fool, yet how frequently we deserve it!

In all such places, where the animal life is shy from long persecution, and you may not see a mouse or hear the squeak of a chipmunk, there will be insect-life without stint; and this, at night, is superlatively noisy. Leaf crickets and katydids may drown all other sounds, but besides these there are the buzzing and humming of moths and beetles captured in cobwebs, and such sounds are not always interpreted at once. Hearing such a 
sound as this, I crept cautiously for some distance, not long ago, certain some preying mammal had its still living victim in the trees overhead. Moving almost noiselessly along, watching the trembling leaves of every branch above me, and locating the sound, first here, then there, and when at last sure that I had come upon a raccoon in the birches just ahead, my face came in contact with a dense web in which a beetle was entangled. Its buzzing, now low, now loud, a veritable wail of despair, could have been heard, I think, in the still night, twenty or thirty rods away.

At last, I left the woodland path and entered a clearing, an open space, with grassy sod softer than velvet. The winds, whichever way they came, swept it carefully. Near the center was a low mound, with a few low bushes near it. Longer ago than any one now living can remember, John Watson had his cottage here, living alone, and, when not dreaming, playing on his flute. At the door of his cabin, so runs the story, he would sit when the moon shone, and charm the wild life of the woods about him. The fox and the hare, the raccoon, the opossum, and all the smaller creatures came and circled about him as he played. This is, of course, an exaggeration; but that music, or any strange and long continued sound, will rouse the curiosity and banish the fear of many animals is incontestable. I thought of this when I reached the mound and sat down upon the one projecting 
foundation-stone of the old cabin, and, thinking, began to whistle. It is an accomplishment that I never mastered, and not a creature was charmed. My lips became dry and my cheeks painful, but all in vain. Not even "Auld Lang Syne" could tempt so much as a meadow-mouse, and I gave it up for a far more pleasing pastime. At least I could fancy myself John Watson, and the same old oaks and silent moon gave every opportunity for rebuilding the past. But suddenly all this was stopped by the sound of approaching footsteps. Last year's leaves were rudely tossed aside, and small twigs were snapped. It was an exciting if not anxious moment, and then a dog came trotting into view, more astonished to find me here than I was relieved to have suspense ended. He stopped, he stared, and then, not venturing to pass by, turned as suddenly as he had appeared and bounded into the dark woods.

Such commonplace conclusions to what promises at the beginning to be an exciting episode do not commend moonlight outings in a long-settled locality. I was somewhat disappointed, and came down to the level of sober fact with the ever present regret that the place was so devoid of adventurous features; a regret that was quickly dissipated by a shrill whistling, as if its owner were calling the wandering hound that I had just seen. It was not so ordinary a matter, but a longdrawn line of ducks that were speeding toward 
the river. I recognized the sound, but where were the ducks. The sky was clear as crystal, and I had seen the bats occasionally cross the face of the moon; but no dark streaks were seen even where the light shone brightest. There were many of them, judging by the sound, and they flew but a short distance above the tree-tops; yet I failed to see even a single one.

The woods were very dark when I reëntered them; and because a mist was gathering, I suppose, the light that straggled through the intertwined branches of the trees was not diffused but solid like pillars, and I thought of the ghosts of those trees that once stood here: ghosts of oaks and beeches and stately liquidambars, compared with which the present trees were pygmies. Standing in these pillars of misty light, the forest was very dark beyond their boundary, and passing into the unlit woods these same lights seemed not to cast any shadows, but to illuminate themselves alone. It was a cold, cheerless condition that I had not found before; one that made the darkness visible but could not dissipate it. I was glad to reach the wide, open meadows and to know that the river was not far off. The moonlit meadows! There 's music in the very name! Mist, as I stepped upon them, was rising from all the damper portions and rolling its filmy waves over the pastures. Not an outline was distinct; yet there was light enough to dispel all doubt. The brilliant 
golden bloom, sunflowers of several kinds, and the yellow tick that grows on every bank of ditch or brook, were now in mourning. The blossoms appeared almost black in the hazy atmosphere, but this was the only uncheerful feature. Everywhere the air trembled with the songs of insect life, yet loud as was the sound made by these busy millions, it did not drown the coarse cry of the herons that flew by me. I startled two that had no expectation of being disturbed. I could see where they settled by a deep ditch, and walked more carefully, that I might watch them feeding. These birds have acute hearing as well as excellent vision, and it required some care to reach a commanding outlook, and not be discovered. This I did, however, and was well repaid. What a superb bird in these commonplace corners of the country is the great blue heron. I supposed that they were all quietly at home at this time of the night, but this pair were wide awake and seemed as much at ease in the moonlight as when, at noon, they stalk like sentinels the muddy banks of the creek or skulk among the reeds and wild rice on the river shore. The birds before me were feeding, but what they captured I could not tell. Their stately figures cast grotesque shadows on the still water, and their actual movements were ludicrous as I saw them, the birds being inky black, and the narrow necks not always discernible, though the head and back were. 


\section{Whotes of the Whigbt}

At irregular intervals one and sometimes both would thrust their heads into the water, and I could see the silvery-tipped ripples on the surface when they withdrew. At times, miniature clouds rose up and, floating by, obscured the birds wholly or in part, and then, as the white mist disappeared, the herons would raise their wings as if to fly, and look thrice their real size. It was as if they shook the moisture from them; but I doubt if this were true. Then, as I too had an errand, not at but over the ditch, I walked leisurely forward, and the birds again rose, but high in air, and after circling over me for some time, flew toward the woods. I trust they had had their suppers before I last disturbed them. I hoped while near this spot to hear the bittern boom, but it was too late in the season, and the birds have been gone for some time. During the early summer a single bird took up its quarters much nearer my home, and I could not only see it often, but was daily entertained by its strange utterances. Why the bird had no mate was a constant source of wondering, but none came hither, and not until late in summer did my bachelor bittern vacate his lonely quarters. I saw no other herons this night, but it must not be supposed that only the true night-herons are likely to be met with after dark. The whole colony that nested in a sink-hole in an upland field were often very late in leaving the meadows for the last time, even when there was no moon. 


\section{Whotes of the Whigbt}

Crossing through bushes that have grown breast-high on a neglected tract, I still heard the rattling squeak of the night-hawk, and saw several, or the samc bird many times. They are crepuscular rather than nocturnal, as a general thing, but the warm air to-night, although so late, kept insect-life on the wing, and so the mosquito-hawk remained abroad. Here, as usual, the habits and food-supply are closely linked, and as the latter varies continually and in different localities, it is not strange that observers differ a good deal.

As there were no cattle grazing here to-night, I was the most conspicuous moving object on the meadows, and I wondered if I was watched as I had been watching. Whether so or not, it was with no real pleasure that dark objects before me would suddenly disappear, as if crouching in the weeds, and no more show themselves. It was in every case probably a trick of the shadows, but, then, how can one be certain of this? To be shoulder deep in a dense jungle of stout weeds and thinking, at the same time, even of impossible danger, is not calculated to increase one's interest in moonlight; but it was then as bad to retrace my steps as to go forward, and at last, with a feeling akin to relief, if not actually that, I stood on the shining, sandy, pebbly beach of the river. I reached the stream near where Peter Kahn, the Swedish naturalist, 
one hundred and forty-six years ago, was becalmed, and lay awake all night because of the whippoorwills and frogs. Neither were noisy now, and the ripple of the tide, where a few pebbles checked its flow, was the single sound that I heard. It was apparent that my coming had disturbed all lurking life that happened to be near, and I stood quite still until confidence was restored. The unanticipated occurred. The first sound was that of a dog growling uncomfortably near, and then the voice of an old acquaintance, Bill Pullen, the hermit fisherman. Nothing can please me better than such a meeting by day. But if he should prove talkative to-night, I was indeed unfortunate.

"Well, Bill," I remarked, when he had called his dog away, "I 'm sorry to disturb your fishing?"

"You can't disturb me, as you call it, if I don't want to be. The world 's big enough for both, I guess, and if you can keep on your own legs, I can keep on mine."

It would be hard to say if this was a welcome or not, but it did not disconcert me. I knew my man, and stood for a moment watching the play of moonlight on the water, and then said-how commonplace we are at times! - "This is a pretty night for a walk, if you like Nature."

"Well, is there anything better to like? I 've been livin' in my cabin on the island for more 
than a year, and don't want better company than what I find. There 's only two things to bother me: men and lightnin', and which is worst ain't easy to say."

"I 'll take the hint and move on," I said and stepped to one side.

"Oh, no, there 's room for both," Bill replied with a suggestive change of tone and manner.

"Then you contradict yourself," and I made a second move to one side, as if to continue my walk.

"Did you ever see the man who did n't? It 's this everlastin' sayin' one thing and meanin' another that made me take to a house-boat for a change, and then to a cabin on shore. I sell my fish or game and get what I want out o' the town, and that 's all the use I have for it. This livin' alone, as you call it, is livin' with more company than you can pay respects to, and you know who you 're talkin' to, which is more than you can say about town gatherin's. When I see a snappin'-turtle and his eyes flash fire, he means all he looks, and you 're a fool to mistake him. We keep clear, or it 's an open fight, if I 'm after his carcass. There 's no underhand work, like your town snappers."

I knew he was right, but was not disposed to lose my chance of studying the night by idle discussion about savagery and civilization. I am as strong a champion of the former as he, but prefer 


\section{Nhotes of the Whigbt}

action to argument. Bill, of course, had been, or fancied he had been, badly used, but what good could come of expressing sympathy? I kept my face turned away, for the moonlight was growing brighter and the river more sparkling, hoping he would soon be talked out. No one heeds the whimpering of the under-dog, and I hinted at this, but he was not to be diverted from his chance to growl.

Not seeing, or pretending not to see, what I wished, he continued: "You 're right, it 's my own business, but I can't always keep quiet. Let us take a look at what's about us and maybe you can learn something, just as I 've done by bein' alone here. Talkin' to your own self is only bein' in bad company, when you 've got yourself to blame. If you're square with yourself, sometimes it 's talkin' worth hearin'. The river and these trees and bushes don't hint at things, as you done just now, and leave you wonderin'. They speak out, and it 's your own fault if you don't understand 'em."

"What have you learned," I asked incredulously, "by being here alone, that's worth knowing?"

"I 've learned nothin' but what 's worth knowin'. There 's more out o' books than in 'em, as there's more in the ground than out of it. If what you get by keepin' eyes and ears open is n't trimmed down and spruced up to suit your town folks, you know it 's the genuine article, and you 've 
run no risks o' bein' swindled. What you see from the excursion boats that go snortin' up the river is all on the outside o' things, though the folks don't seem to know it and go home talkin' like the parson; and that 'minds me I was guide once for a man who thought buyin' a gun made him a hunter; but when the rub came, there was n't a rag left to cover the feller. Of course, he shot every duck he took home, and never heard o' Bill Pullen. You can't cheat Natur' by puttin' on airs. It don't always happen that a man 's left money and brains too, more 's the pity. $\mathrm{He}$ can't buy one with t'other, and it 's t'other that tells in the long run."

"Did you come here, Bill, just for the satisfaction of getting at Nature at first hand, or only to get a harvest to carry to town?" I asked, trying to bring his wordy discourse to a close.

"If I 've got to live, what in thunder 's the reason I can't live in my own way, and think accordin' to my light? I ain't treadin' on my neighbor's toes or gettin' my elbow into his ribs; so, no offense; but what brought you here, if you don't like it, and at dead o' night, too?

"Oh, I came out of curiosity. The world looked so strange from my windows that I wanted to see what it was really like," I replied.

"You came out o' curiosity, and I guess you 'd better go back to it. Stay in town, and when the sun goes down, stick close to a lamp-post." 
I laughed at his suggestion, as it might readily be misconstrued, and then interrupted him by saying, "I live in the country, Bill, as you know very well."

"Yes, live in the country, but the country does n't live in you," Bill retorted with a chuckle, and he had said a good thing.

It was humiliating to find that I could learn so much from this unlettered aristocrat of the marshes. Here was cranky Bill Pullen, as my neighbors called him, telling me wholesome truths; for his words, though a bit wild at times, were weightier with wisdom than with nonsense. He was, in fact, not merely a hunter and fisherman but a " natural" philosopher, and showed how true it is that freedom of action is freedom of thought, that freedom of thought is freedom of expression, and what is this but the very best of our literature?

Bill, at last, had had his say, and seeing that I looked about for a seat, he gathered an armful of rushes and twigs, which he wound about his arms until they were interlaced, and then handed me a cushion soft as the patriarchal mosses of old woods.

"The river ain't the same all the year round, in the moonlight or daytime. It 's somethin' more than the water in its channel," remarked Bill, after some ten minutes of silence.

"So I was thinking when you spoke, and I wish I knew just what the difference is between now and last winter, for instance. It 's something 46 
more than ice and snow instead of water and green leaves."

" Think it out for yourself, while I go look after my traps, and get ready for bed, too, for I don't sit up all night like an owl," and Bill left me to my meditations, without further ado.

Perhaps it may be that I was growing sleepy and did not realize it. It was late now, and would be nearly dawn by the time I reached home, and these thoughts doubtless dulled my observing power. The river was not strange to look upon. The sparkle was losing its dulness, and my mind wandered to what had been, an excellent evidence of decaying strength. The increasing indistinctness of the waterscape led me to recall the brightness of every object seen in the springtide light; and a word here concerning this light of the new year. During the closing days of February it may be very cold or an ethereal mildness may prevail, but whether it be the one extreme or the other, there is a marked difference in the sunshine. There is greater actinism now, if I understand the physicist, and this means the chemical force of the sun's rays is more pronounced. But if this were the sum and substance of the matter, what comfort would the rambler get? Naked facts are thrust upon the world from the laboratory, but nature drapes them daintily before presentation. What concerns me is that a little cedar on the other side of the river stands out to-day as 


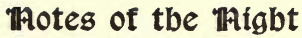

it never did in January or June, and for me it is a sign that spring is coming. Does the chickadee know about actinism, but by another name? Today there was no midwinter cheer, delightful as this is, in the wee bird's call, but a suggestive, anticipatory ring that brought up a vision of the first flowers of spring. The season may be weeks upon the way, snow-bound and all that, but the sign of the cedar will remain. The horizon will remain as clearly outlined as does the tree that towers above me. I have faith in this springtide light that knows no wavering; this kindly light of a promise that has never failed.

And so, too, has the life about me like confidence. Even now, sheltered by last year's leaves, are swelling buds, and frogs are astir in the warm waters of the throbbing springs. This clear, white light is a happy medium for sound, and the whistle of the red-bird has the ring of a silver bell. The gentle hint of bud and bird to enjoy in anticipation should never be disregarded. Not that, in nature, realization falls short of expectation, as is almost the usual course of human affairs, but why not get a double measure of blessing, if we can? There will be many storms and much snow and ice, it may be, before we see a green leaf, but these cannot dim the magic light or blot out the cedar that stands upon the river shore, signaling that the world awaits the coming season.

This light is no fancy of a fevered brain, to 48 


\section{Inotes of the IAigbt}

which our eyes are really blind, nor is it a feature of but a part of each day. It is present at daybreak and as the mists roll away; for they do roll over and over until out of sight. The earth has a strange look. The surface of both land and water follow the mist, or at least move slightly upward and come more distinctly into view. Fancy some huge creature turning over on his couch and tossing away his blankets. The world is wide awake at daybreak, and though the robin was not here to-day, there was no lack of announcement. The song-sparrows that so gallantly defied the winter, and sang even before the coming of the springtide light, sing now with greater joyousness. Other birds, sturdy songsters that came last autumn from Canadian forests, still keep to their roosts or only peep out to scan the promises of a sunny day. At last, the sun rises, changing the pearly dewdrops to brighter gems, adding a little to their glory before destroying them. This magic light is not destroyed but intensified at sunrise. The level rays of the sun have a fashion all their own, and how few have marked the strange shadows that are cast. That of a tall tree-trunk before me is now moving its way toward the western horizon, while the branches are yet in unsunned light. A quickly passing phase, this, of the many-sided day, and likely to escape notice, but not so the lighttipped buds of the maple. Ruddy, though the day be dark; but now, how each dull bud becomes 


\section{Nhotes of the Whight}

a ruby! Through the night, the syrupy sap has been oozing, and the frost has crystallized it. What confectionery! I have eaten frozen maple buds, and they are sweet.

The ravine, thick-set with rhododendrons and a squatty hemlock growth, vainly resists the rising sun's attack. I can see now a long alley of light that leads to some dripping spring cave in the colored clay, and for a brief moment its secrets are laid bare. But the sun is no laggard. He travels faster now than at noontide, and is up and ready to peer down upon us before we realize his journey has begun. Time flies, but the sun goes bounding from a catapult, and this first act of the diurnal drama is little more than a quick scene-shifting; and few are the actors, and fewer still the words they speak. There is matchless quality, though; and songs at sunrise, when birds are the artists, linger longest in our minds. It is the magic springtide light that quickens our every sense, and for once at least brings us in full sympathy with the fresh new world.

The month passes, and all that we have confidently predicted will be found to have been made good. March accomplished more than merely blowing out the old and in the new; and in this same light, now heavy with overcrowding of sights, odors, and sounds, we have, in April, fulfilment. The buds are now blossoms, white as the driven snow, ruddy as the blushing rose, fragrant beyond 
compare, and all bathed in the clear springtide light, that trembles with the melody of merrythroated birds.

But although all through April there was the hum and buzz of activity, yet few comparatively were the visible workers. The prying sunshine found its way to the innermost nooks of every dark ravine, and flooded with a pale shimmer the thickets, even where the greenbrier was tangled until almost a solid mass. There was everywhere evidence of the progress of some mighty work, yet had some forlorn mortal from a barren land chanced upon the scene, he could not have told you what was under way. To me it was an old story that I have heard and seen played for many a year, yet the novelty is as pronounced to-day as when I first stood and wondered if the opening buds heard the rejoicings that greeted sunrise when the year was new.

To be able, in age, to greet with the delight of childhood the cycling of the seasons should be sufficient to keep alive the spark of juvenility, even when the years bear heavily upon us. Who would willingly lapse into such a state as that which prompted this outcry?

Tedious, when Winter roars athwart the main,

To see the same sad tracts of endless snow;

Tedious to see, when Spring returns again,

The self-same hawthorn bush and cowslips blow. 


\section{Thotes of the Mhigbt}

All through April the work has been in progress, and now what of its completion? Winter's carpet of sered leaves is no longer that broad and brown expanse, suggesting the dead past only. Where the wild March winds have worn it away the arbutus glows, pearly and pink, and the lingering snowdrifts have given place to long lines of bloom as purely white as they. The rank green grass has pushed aside the black mold winter left in its path, and the ascending sap, that silently coursed the maze of the shrubs' tangled branches, has bidden every twig to fling out a greeting banner; for May, the young queen of the coming year, demands all honor. Even the gnarly oaks, the stately beeches, and low-bending elms, that stood, bare-armed, resisting winter, yield to the all-pervading magic in the air and renew their allegiance to the dainty queen. I would there were one word that fitly described May and her magic: the word is not yet coined. But is this all? Have we but the change from a dead brown to a living green, from bare twigs to rosy blossoms, over which to grow enthusiastic? Are we to grow young again because the tree-tops are again in leaf and the gray meadows bright as a summer's sunset? Is it not enough - this day-long feasting of long-hungry eyes, and scented air to breathe? But May magic works yet another marvel: sweet sounds succeed to silence-not absolute silence, but comparative; for the touch that awakened even the old oaks has 
thrilled the springtide warblers' throats, and what a concourse of sweet sounds! The long avenue, hemmed in by stately pines, has ever a power to hold us, though the coldest blasts of winter rush headlong through it. It is a bit of nature's masterpiece in mere woodland scenery; but when the south wind breathes upon it, and urges, too, the early thrushes to return, they are straightway moved to sing in the marvelous light beneath these mighty trees, and we know then the fulness of bird-melody; and this is but the opening chorus of the young summer's merrymaking - the second and greater performance of May magic.

But, wander where we will, we find no partiality shown. There is no neglected spot, whether in the upland fields or in the meadow, the gloomy marshes or the river's lonely shore. I have said the "gloomy" marshes; they are not so now. The fairy, with her life-giving wand, has threaded their hidden paths and awakened golden bloom of wondrous brilliancy. Not a recess in any marsh is too remote, and hither have been led whole hosts of merry warblers, as bright of plumage as the flowers are gaily tinted. How well they blend! It is no caprice of a madcap that brings them together. May's magic is well considered; and, for the day at least, the "gloomy" marsh rings with the happiness of thanks-giving throats.

It is probable that without birds, and indeed $4^{*}$ 
all animal life, the magical influence of May would be quite lost upon us. Birds and blossoms - they are ever so intimately associated that either suffers when the other is wanting. The winter songsters, of which we have so many, are, in fact, not overmuch given to singing until well after the holidays, and it is in early February when they ring out those wild choruses that sound so strangely in the naked woods. Is it too much to say that they are but practising in anticipation of the coming season? Whether this or not, it is now that the springtide light fills the landscape, but with less distinctive brilliancy, it may be. As compared with all the coming summer, there is, as coldly stated, greater actinism now; but does the chickadee recognize it, but under another name? In birdlanguage, it is May's search-light sent far ahead of her coming, and it sweeps the rubbish of last year from the air. It stimulates the birds as it does the rambler, for vision is clearer now, and sounds come from greater distances, and nothing of them is lost.

Bill's dog cut short my meditations. A low but most expressive growl brought me back to the present, and there was little left of the moonlight to make clear my homeward path.

"Have you been a-dreamin'?" asked the old fisherman, coming up to me. "It 's nearer mornin' than midnight, and you ' $\mathrm{d}$ better be on the move, unless you got cats' eyes." 
"Good-night," I said, in reply, and with but the one purpose urging me, I hurried homeward.

Bill Pullen may have thought he had seen the last of me, and, in fact, he said as much, inquiring of a neighbor if I was "roamin' round with a fever"; but I was not so far astray, mentally or physically, as he supposed. I found him, but two days later, as the sun went down, and bargained for a boat ride. I wished to sit quietly in the boat, and be rowed hither and yon as fancy dictated. He considered awhile and assented, but I had to pay a good round price. "Nat'ral fools ain't to blame; but if you play fool, you 've got to pay," he put it, and I was engaged therefore, as he held it, to play fool by moonlight.

Bill drew the boat upon the muddy beach, at the end of the island, and there we waited for the moon to rise. The most intense darkness filled every thicket on the island-shore, and the tree-tops blended so nearly with the blue-black sky that their outlines could not be traced. A slight breeze swayed them, and, hiding and revealing the myriad stars, gave the sky a lively motion that even moved my companion to remark that the stars were peepin' at us round the corners. The hum of insects that made the meadows fairly tremble came softened to a muffled sound, like the distant thunder of midsummer. After some minutes spent in idle waiting, nearby sounds came from every direction, and I would, if alone, have 
been confused on attempting to identify them. Here was opportunity to test Pullen's watercraft, and I put it to the proof. "Tell me, as you hear them," I said, "what makes these sounds, croaks, grunts, and whistles."

"So you don't know a duck's whistle, eh ?" he replied contemptuously. "Well, there's more than one that can whistle clear as a fife; and then there's fish that come to the top o' the water and sort o' splutter. Noises! why, man, except in the dead o' winter, you 'll always have noises along the river."

The rippling of the water under the boat's stern was music, and what wild imaginings when some more sturdy matter than a wave struck the boat's bottom. I did not exclaim "What's that?" at every new sensation, for Bill was sick of his bargain and sullen. I left him to the enjoyment of his pipe and private thoughts, for the moon was now shining above the tree-tops. What questions I asked, I asked of myself; and if wrongly answered, there is no one to blame. There's always satisfaction in that.

For some distance beyond the boat the water was black as ink; then a fitful pearly tint showed where the waves were crested, and beyond the first real silvering of the water was seen - a mere shining thread that sank and rose like floating phosphorescent twigs. Steadily, as the moon reached nearer overhead, the lights grew brighter, 


\section{Thotes of the phigbt}

and every ripple, save those within arm's reach, was fire-tipped. Torches innumerable, but no visible torch-bearers. And now the weedy shores and scattered trees came creeping into view. Timid, I fancied, as if wanting to see and yet remain unseen, but the moonlight caught them all at last and pushed them to the front. Now, as never before, could I see the river by moonlight, and my half-asleep companion was right, there were noises on every side, below, and above me. Not a single sound, save that of the ripples beating against the boat-each ripple rang some fairy golden bell - was peculiarly distinct, and in the midnight air all were strange. Even the notes of some familiar birds are changed by such surroundings, as the cry of a catbird which enlarges to the wail of some feline monster. The nightsong of the rose-breasted grosbeak, however, is even more magnificent than the same utterance by day. This bird is a poet that appreciates moonlight, and is doubly inspired when the world is wrapped in silence. Heard, as I have heard it, when on a wide expanse of water, every note is freed from its harsh elements, few though they be, as it travels toward you, a spirit's voice rather than one from any material source. And now came the great surprise of the night - and every outing to be successful should have at least one unexpected incident-great schools of fish went by the boat, and many a shining head with va- 
cant stare peeped at us from the curly crests of the ripples. Long lines of glittering bubbles were left behind them, and then these were scattered by other fish that, following in the same track, went through the same performance, a greeting of glassy stares and beady bubbles. These fish, old Pullen said, were mullet, and I knew by that name he meant a small sucker - a catostomoid of the ichthyologists - that was found in all our waters, even to the meadow ditches.

I have spoken of the bubbles of air left in their wake as they passed by the boat. It was easy to detect a faint, sibilant, tinkling sound made by the mullet as these bubbles were left upon the surface, but it was a peculiarly mechanical and accidental sound of no significance. $\Lambda$ distinctly vocal note is made at another time of year, not unlike this, but undoubtedly an utterance, and not an accident. Made in the same manner, perhaps, but $I$ think not, but certainly made for a given purpose, and in all essentials an intentional call to others of its kind, the movements. of the fish indicating this quite conclusively. Such traces of voice in fishes are nothing new to naturalists, and I roused Pullen to discuss the subject from his point of view.

"Have you ever heard that fish make noises?" I asked.

"Sturgeon can grunt and big catfish squeak," he replied. 
"But do they make these noises of their own accord," I asked, "or only when they 're caught ?

" Both," Pullen said, very positively, " but they ain't just alike. Any critter will squeal when you hurt it, even a fish sometimes, but what I 've heard when the fish was n't meddled with was clear squeakin' 'cause they wanted to." And then, after a pause, he continued, "You can often hear a run o' fish, when there ain't any other noise, makin' a sound that ain't just splashin' the top o' the water. I've heard big fish, out in the meadows, makin' a hummin' sound."

"How do you know it was fish and not frogs?" I asked.

"' 'Cause I know what sounds other things make, and when I ' $m$ in my boat and hear what nothin' else makes, it 's fish. What else could it be ?"

"Perhaps somebody was asleep on the bank and snoring," I suggested.

Pullen was fairly roused by this skeptical questioning on my part, and exclaimed impatiently _-! I will not repeat his monosyllabic reply. The old man was right. I knew this; but careful questioning is very necessary sometimes to get at the facts you wish, held in the grip of these unscientific naturalists. There is a tendency to overstatement that may mislead, or of understatement that leaves you in the dark. At least a considerable number of our fishes have what we may rightly call voices, and may it not be that if we 


\section{Motes of the Might}

had more sensitive ears we could detect the utterances of the small fry that crowd the shallow waters literally by the millions?

Fish of several kinds passed by, and occasionally a silvery perch or rockfish leaped into the upper air, shone brilliantly as a meteor for an instant, and was gone. This sudden disappearance into the black depths brought many a thought to the foreground. What of these depths ? This long river bed for centuries has been before our doors, and for thousands of years before our homes were built, yet no man can be said to have seen it. What strange processions pass to and fro, from the broad sea to the narrow mountain brooks and return. The highway of another world than ours, that we pass over and plough through, that we choke and defile, and yet never see in its entirety, never learn one tithe of the secrets it holds. We may pass a lifetime on the banks of a river and meet with as many novelties during our last days as we did at the beginning. Because, years ago, I had found every fish down in the books, I assumed to know all about the Delaware, but now I find little flatfish, a marine flounder, common away up in the freshest water, and sometimes they wander beyond the reach of tides. There is nothing of this in any book that I have seen, and one of those closet pests, a book-naturalist, says I am mistaken. Let the fool slide. And what may not be true of other forms of life from the deep 


\section{Whotes of the Migbt}

sea? I can imagine smaller fish wandering miles from the bay and yet escape detection; and we know how large creatures like the porpoise and seal often come, and I am assured that a shark has been seen more than one hundred miles from salt water. Here in our river valleys and the river's bed is opportunity for field work that will change the complexion of more than one handbook of zoölogy.

River-beds are not our only unexplored territories. Who has ever covered even so much as the ground of his own door-yard? Never a day but we are compelled to ask questions, or would ask them were we not content with our ignorance. I have sometimes questioned whether the widespread indifference to nature is not telling evidence of an enfeebled intellect. Not that with this indifference man or woman may not fulfil all of life's requirements, but the fulfilment would have shown out with greater brightness if, coupled with strict attention to duty, there had been an enthusiastic love of what, besides ourselves, constitutes the world. A few hundreds of men and women huddled in a city, breathing foul air and the sweat and smoke of a thousand chimneys, may hold as nothing all that lies beyond the limits of their daily lives; but that outlying "all" has greater reason to hold them in indifference. What a contradiction, when we hear a man or woman extravagantly admire a land- 
scape that has been cunningly put upon canvas, and yet express a distaste for the very country that the canvas reproduces. Such people, it seems, hold it an insult to be told that they are silly, perhaps with reason; but they are silly, nevertheless, and I fling the assertion in their teeth here, as I have done, time after time, to their astonished faces. Let them disprove it if they can, and then will be time, and time enough, to reconsider my decision that indifference to nature indicates a mind lacking an all-important feature. Love of the out-door world is as essential to a perfectly rounded-out character as strict adherence to the commands of the Decalogue. It is an eleventh commandment; not least though last, and, though the one most pleasant to obey, the one most generally disregarded.

In spite of the facts, we are even told by these indifferent folk that man should have higher aims than a love of nature. As if we could climb a higher mountain and look down on heaven. Not all the strange stories get into the newspapers. A woman recently remarked to a friend of mine that she was surprised at her giving so much attention to birds, and flowers, and nature generally, regretting she had not higher aims in life. When I heard it, I wondered what manner of woman it was who could make such a remark, and was a little curious to meet her - at a distance, for this would lend enchantment to the view ; but when I learned, 
indirectly, that she had said there was a lurking danger of atheism in the study of natural history, I gave her no further thought, for such a creature deserves consideration only from the missionaries. If men or women of this sort abound, what are our teachers about, for these unfortunates were children once and went to school to be instructed. I have never met with nature-hating people and speak from hearsay only, but how to be pitied are those who daily meet them! I can scarcely imagine such phases of humanity - distorted, if not diseased - but in comparison to those I do meet, such creatures must be very like caged canaries, a pitifully poor apology for our native song-birds.

The most exciting effect seen on the river this night was the wake left by some creature that held its head well above the water. I thought at once of snakes and the muskrat, and finally, to satisfy myself, roused Pullen for a decision, and he suggested an otter. This was so improbable that I ventured the opinion it might be a mink. It was beyond our vision's range before we had quit discussing the animal's identity, and while gazing after it regretfully, I detected the creature heading toward us. It was a thrilling moment. The black dot came rapidly nearer, and the widening wake, like diverging lines of silver chain, reached out until lost in the outer darkness. I almost held my breath as the unknown swimmer came within an oar's length, and then Pullen and I, at the same 
moment, exclaimed "Snake!" I was terribly disappointed, as I had hoped for an adventure, and asked my companion if we were right. "That or an eel," he replied, "and snake most likely." I accepted the decision and was about to say something of the large water-snake of our river valley, when Pullen exclaimed, "Look out there!" and pointed to the other side of the boat, which lay in shadow. There on the oar was the snake, resting, and in the dim light I could just make out that it was one of the largest.

"How big do they grow, Pullen," I asked; "as long as the oar?"

"They 're only that long when they get in the papers," he replied, and I could hear him chuckle deep down in his throat.

"Are you afraid of them ?" I then asked, in a tone suggestive that I was, though I am not.

"No, man, they 're all right. What have you been doin' all your life not to know that? Seems to me you don't pan out much when you 're out o' your house. What 's the matter?"

There was no use in explaining, and I was greatly relieved when a sudden puff of wind came from off shore, which roused my sluggish companion so that he shook the oar and drove off the snake. I did not venture on further questions, but breathed in the rich odor of the ripened leaves treasured sunshine of long summer days - brought to us by the breeze, and with it came, I am sure, 
a few sweet notes of a wood-thrush, some migrating minstrel dreaming of the dead summer. I forgot the moonlit river when I heard this song. I made a cushion of whatever was available, and, lying on my back, looked up at the moon and the fleecy clouds that passed by and over it, and thought of wood-thrushes as I had known them in the days gone by. I could picture every nook and corner of the farm where I was a boy, and again I went after the cows at sunset, passing along the narrow path among the hillside oaks, along the greenbrier thicket that few birds even could penetrate, and then out into the open meadows to the lone hickories where the cattle congregated at noontide. There was not a bird of all that country that I did not know. The chewinks scolded as I neared their nests, the song-sparrows chirped an alarm as I approached, the peewees rose to the higher branches in the tall trees, and how the catbirds fretted! I was not their enemy. I had never robbed their nests, and yet they were all sore afraid for the simple reason that I was a boy, and they had cause, they thought, to mistrust me on general principles. A little later, when I came trudging back, loitering long after the last cow had passed, there was one bird that had confidence, and young as I was, it held me by its marvelous song,- - the wood-thrush. In the gloaming, when the woods and every field were deserted by man, when the tireless songsters of the sunny day were all wearied 
and worn out, then the thrush filled every lone pathway with its sweetest notes; sweet yet sad, a song of one who had loved and lost rather than happy with its listening mate. Loitering still, I would watch the songster until it was too tired even of such music as its own, and dived into the tangled thicket for the night.

I recalled the breaking of many a dewy spring morning, when, while the unfolding leaves were dripping and scarcely a swallow had ventured into the murky air, this same thrush had already shaken the moisture from his nut-brown wings and sang as if sadness were a thing unknown. And how I lingered at the meadow gate, those juicy spring mornings, listening and wondering with wide-eyed surprise that the world should hear so little of all this woodside melody. Could it be possible that this bird was singing only for my pleasure?

I remembered the first of the nests of these birds that I had seen, in the old apple tree near the kitchen door, and with what excitement I saw the four blue eggs in their rude cradle of dead grass. I could still feel my grandfather's finger clasped in my hand, as when he led me to the spot and lifted me well up that I might see; and how still we stood when the bird began to sing!

Never a year since then but.I have watched for the coming of the first thrush in spring; never an autumn that I have not marked their departure 
with regret. We read with feelings akin to envy of the nightingale; but let us be thankful that the music of a wood-thrush has been vouchsafed to us.

My pleasant thoughts were interrupted by old Pullen calling out, "Ain't you never goin' home?" I had not thought of such a thing, and on examination could not discover that I was sleepy. Indeed, the thought of a rather long walk over lonely meadows at such a time was not pleasant to dwell upon, and I asked, "Can't you stay a little longer?" "Got to, I s'pose," he growled, and sank into his corner like a surly dog.

A moment later, a kingfisher passed over us. There was no mistaking the bird's flight, and there was no need for the bird to announce its coming by springing a rattle, as it does in broad daylight. Do they often fly at night, even when light as it then was? I could learn nothing from Pullen. This bird, it would seem, entered as much into Indian folk-lore as its cousins have figured in European legend. Its strong beak has been found in graves, with other trinkets, and there are songs and stories about it in the Lenâpè tongue. I have since had opportunity to inquire as to the kingfisher's habits, and find a difference of opinion. One miller was positive the birds at his pond were active on moonlight nights; another said he never had seen evidence of this. My suggestion that he never particularly noticed them or any birds was met with an indignant denial, and 
I found him well posted as to all the birds of his pond-side. Be it as it may, the kingfisher I had seen came again over our boat, and, startled by my shouting, uttered its characteristic rattling cry. As schools of minnows continually rippled the surface and then spread out in every direction when frightened, it seems quite probable that a kingfisher could see to seize one by the light of a full moon. But I did n't see my kingfisher do anything of the kind.

Pullen now insisted, and with reason, that we return, and seating himself at the oars, he rowed me to the point of our embarking and bade me "Good-morning" with a tone full of unexpressed meaning, adding something about "the toughest job he 'd ever tackled." I was glad to be rid of him, and yet the walk before me was not pleasing to anticipate. It was long after midnight; every cricket even was quiet, and my own footsteps were all that I heard. It was growing dark, too. Clouds were gathering from all points and threatened to soon enwrap the moon. I quickened my pace, and, familiar with the ground, made good progress until the weedy, tangled meadows were reached. Then my steps were stayed. I stumbled at times and was well nigh out of patience when a marsh-hawk flew up directly in front of me. I could see its long tail, white rump, and stretch of wings ; and I watched it for a moment, wishing then, if ever, that I had the power of flight. 
When the bird was gone, I continued to think of it and hawks in general, rather than my uncomfortable journey, and the path was smoothed by so doing. In short, I let my legs and instinct find their way home, while I busied myself with other matters.

It is not until the end of August that the hawks become noticeable. Even the little sparrow-hawk that nests in hollow-trees and, if looked for, is to be found all summer, is not conspicuous when the trees are in full leaf and acre after acre of idle fields is breast-high with weeds. In June, and later, I see many more of them along the river shore than inland; but now, when there is a hint of autumn in the passing breeze, I see the swallow-like blue-gray hawks, three kinds of them, darting over the wilderness of wild rice, a terror to the gathering reed-birds and huge flocks of redwings. Later, the great marsh-harrier sails majestically over the mucky meadow, and sweeps the tapering points of the wild grasses and dull-gold growths of the heavy sedges. The sparrows rush madly about, and seem too terrified even to chirp. Still later, on the dead limbs that project above the surrounding tree-tops, the black hawk and broadwinged buzzard appear, ever on the watch, and usually very difficult to approach. Many a person, strangely enough, will pass by and see nothing of all this; but why so blind as not to $5^{*}$ 
mark the stately red-tailed buzzards, when they come in force, and all day long sail in the upper air of bright October days? These are not all our hawks; but are they not quite enough? One great merit of these larger species is that they localize themselves. They select their outlooks, their roosting-trees and their huntinggrounds, and become so far a fixture of the landscape that I sorely miss them if disturbed, as I would miss the old oaks, the hillside, and the meadows that they haunt. With such wild life about us, we do not miss, as we might otherwise, the so-called sad change from summer to autumn. It is a change, not from activity to quiet, from expanding blossoms to matured fruition, but rather a change from one form of activity to another. From the songs of nesting birds, we have passed, not to silence, but to the exultant screams of wilder life that is not harsh and out of tune, but chords with the sterner aspects of a year rapidly maturing, a change from merry childhood to the realities of adult life. For one, I welcome every hawk I see. They represent a thrilling phase of life that none but a sluggard shuns.

And when the wide landscape is as a sheeted ghost; when the bare trees bend to the north wind's bitter blast, and the river rolls its still, resistless tide beneath an icy fetter that it fails to break; then, with what joy to mark the wary 
eagle in its flight, to see it swoop resistlessly upon the quarry it has marked! We feel our limitations at such a time, and the regal bird's demoniac laugh is, for us, a veritable cry of defiance. Brag as we may, man has yet great strides to make before he can claim the perfect freedom of such birds as these.

I am glad that a petulant little red owl greeted me as I reached the hill-foot. It was perched on a low limb of a small ash sapling, and wheu-u-uu-ed at me as a little dog might bark when I rang a door-bell. It was perhaps a complaint at my intrusion, possibly a welcome; but protest or assurance of its gratification at my arrival, I paused to reply by lamely imitating its notes. My good intentions were not appreciated, or else were misinterpreted, for the owl sank into the depths of the wood's thick darkness, and I was again alone. I was now so near home that the feeling of loneliness was gone. Although there was yet a dense wood to pass through, I thought nothing of this, it was all so familiar, and I rather rejoiced at an opportunity to test the pathfinding faculties of my hands and feet. I could see nothing now. While I loitered with the owl, the clouds completed the sky's veiling, and it was not comparatively but absolutely dark. No cunning vision of owl or cat would have availed now. I readily found the end of the path and shuffled along; but every pebble proved an obstacle, and 


\section{Thotes of the wigbt}

while sure of my footing, I was continually colliding with branches that should not have been across the path. I soon gave it up, although I had but a few rods to go. I struck a match, and directing the feeble light about me, found I had taken the opposite direction and was going toward my neighbor's, not my own home. A few wax tapers soon set me aright, and without accident or incident I reached the garden gate.

At this hour, before dawn and long after midnight, how very silent was all the outdoor world! Every insect was quiet, and not a creature of higher grade, I fancy, was astir. Had I placed my ear against some rotting log, I might perhaps have heard some blind grub toiling where light never comes. Elsewhere the world was at rest.

Thou art a grand artificer betimes,

$O$ hearty Winter, in thy sterner moods ;

Guide me to building of as worthy rhymes

As thou hast wrought in these wild solitudes -

The rugged landscape, where the bleak ice piled

Fills the lone vale where summer sweetly smiled.

Read "lines "instead of "rhymes," and we have a fitting prayer, for who can aptly describe the frozen river, or even the tamer ice-clad meadows? What the latter are, under a covering of snow, we have seen, but there is a great difference between this and acres of smooth ice in like position. The absence of repelling whiteness is a relief. The 
one-time flowery pastures under a snow-bank are too suggestive of the marble at the grave of a friend. Now, it sometimes happens that these familiar meadows, over which I could pass and re-pass forever, are first submerged by the waters of a January thaw, and then winter, reasserting itself, checks the return of the flood by transforming it into ice, crystal-clear and bright blue by day and black as ebony by night. In the light of the full moon of February, I have walked over this polished floor for several miles, knowing the locality only by the protruding trees and bushes. Then, if ever, we have a new world wherein to wander. The sky, except immediately about the moon, is intensely blue, not black, and the stars are golden; but as we see them repeated beneath our feet, the reflected sky is black, and stars silvery. No floor of marble or mosaic was ever half so beautiful, and the play of light and shade when the wind blows is very striking. The long black line reaching from the root of a tree outward indefinitely across the ice bends and straightens, twists and turns, and with such uncertain, jerky motion that you get the impression that the ice is itself in motion. At first, as we observe the trees and bushes that reach above the ice-plain, we have a feeling of pity for their apparent helplessness, but I think it more suggestive really of rest. The wind moves their branches a little, but not in the lively way of leafy days, 
and you think of a person turning about when asleep, or moving an arm in response to some impression due to dreaming. An ice-incased tree is like the uplifted trap-rock that, not far away, towers up from a level meadow several feet above the surrounding plain. Their rest implies silence, and this is true of them, save one. The shagbark hickory has not one tongue within, but a hundred, that girdle it about, and they are never idle tongues. If they do not repeat, they at least sound the notice that something has transpired. Not a breeze can steal on tip-toe by, but one or a dozen tongues will rattle the secret, and when the wind sweeps down from the uplands, charged with a chilly message to the low-lying plain, the hickory tongues "ring out their delight in the startled ear of night." Often have I been misled by this strange sound of the pendant strips of bark as they clashed with each other and struck the sturdy tree-trunk. Is it the frozen sap in the wood, or the empty vessels only, that makes trees in winter so musical? There is a ring to many of them, in intensely cold weather, that is almost metallic. Trees vary in this respect. I know a tall ash without a branch lower than forty feet from the ground that rings like a bell when it is struck suddenly; while an oak near-by, gnarly from the roots up and all branches, tied with a scrap of bark, gives forth no resonance. I am speaking of trees that are frozen - so very 
frozen indeed that they often crack open with a report like a rifle shot.

When intensely cold, however bright the moon may be, wild life does not care to ramble over the wide expanse. There is the good reason for this that no pursuing animal has a chance to conceal itself, and the creatures liable to be attacked can see every suspicious object. I have often wished that a fox might chase a rabbit while I looked on, or even a weasel amble after a terrorstricken mouse. All this is common enough elsewhere, but not on the ice. As the water recedes, there are left huge cakes of ice resting against the trees and along the top rail or wire of the fences. Warm houses are made by the uptilted masses, though usually very dangerous ones for men to enter. Here life finds shelter, and by accident I discovered that in a thicket of greenbrier quite roofed over by ice cakes hundreds of snow-birds and tree-sparrows roosted. Some preying animal, too, made the same discovery, and there was soon a great mass of feathers and small bones scattered about the dead grass. Meadow mice nibbled the bones, and I suppose a weasel killed the birds. We can imagine a great deal of interest transpiring under the ice, now that the water has gone, but it is difficult to witness any of it. If by day, when the sun shines, you look through the ice, you can see where animals have been, but not where they are; and at night, if you put 
a lantern under the ice, you frighten everything off.

Occasionally, if not extremely careful, you are treated to an experience, at night, that may have a ludicrous or a painful termination. The sloping of an area of ice may be considerable, yet the appearance is that of a dead level. You step with confidence and suddenly you find yourself sliding. Any struggle will surely throw you off your feet, and if you steadily slide down, down, you find yourself moving with increasing speed and have no idea of where you will bring up. This frightens you, or did me, when I slipped into a crack about two feet wide, but finding my feet touching the meadow, I felt that I was safe. In many a way in this life it is easier to slip in than to creep out, and so I found that wide crack very ready to accept all comers but not willing to assist at their departure. I had nothing to clutch at that I might draw myself upward, and my struggling tended rather to deepen my footmarks in the yielding mud. At first I was disposed to laugh; then growing weary, I began to look more seriously at the situation, seeing no way out of my predicament. Why for so long a time it never occurred to me to walk along the crack to some other point, I do not know, but the idea came at last, and a friendly stick upon which I managed to get a foothold enabled me to lean far forward on the ice, and gradually I crawled out. 
Such conditions, lacking adventure - and wild life is rarely seen here at such a time - soon become tiresome. We lose ourselves in our own thoughts and forget where we are. The fantastic finger-work of frost is not detected as we pass by, or very rarely.

On my return I found the satiny seed-vessels of dioscorea resting upon the ice. Feathery frost was adhering to their angles, and these, catching the moonbeams, glistened like jewels. It was a pretty sight, but not so charming as these same objects resting on the frozen crust of snow, for at times, like the crimson and black fruits of autumn, they hold on until winter is well nigh spent.

The imperious north wind speaks with precision. You obey or suffer, and no time is left for hesitation. I heard the shrill threat of yet greater cold, and hurried homeward, careless of what came after I was beyond call. After! There are some small words so full of meaning that they forever overflow, and you never see them, but they are dripping with suggestion. "After" is one of them.

After the seed-time, the harvest; after winter, spring; after summer, autumn. After the day, the night, and now, reversing the order, after the night - these long nights out of doors, nights of moonlight and of darkness, of heat and cold, of sound and silence - what of the busy day? Much or little, as you choose to make of it. And at last, what time "Night lets her sable 


\section{Nhotes of the Ifigbt}

curtain down and pins it with a star," when we turn our backs upon, not half the world, but upon the whole earth, is it into the blackness of this night or into the brightness of the star that we enter?

There is none to answer for us. It is the foremost problem of our lives, and one that we alone can solve. 


\section{Tuhen Grass is Breen}

I

THE great storm of the igth, 2oth, and 2 ist 1 of May, r894, was a source of immense delight. It did me no damage, and it was scarcely over before I saw a great volume of water creeping up the creek, and crowding over its banks. This was an old but ever new story; we were to have a freshet on the meadows. Spade-foot toads and all the varieties and commonplaces of the uplands were straightway forgotten, and to be afloat where but the day before I walked was, as ever, the acme of enjoyment. Now there were no inaccessible places, and I grinned spitefully at the quicksands that have so often dared me to approach them. They were effectually bound now, and I was their superior. It is so easy to be brave when there is no danger. And now, what of the country after the storm?

It is always necessary to know what has been, to appreciate what is. The present and the past are linked, though we may find no trace of the 


\section{Waben Grass is Green}

connecting chain. Nature, after the storm, is not always to be likened to Venus rising from the sea; May, sometimes, with her dripping locks, is not fresh, but bedraggled, and there is a shudder in the landscape, as there is in us on rising from a plunge in cold water. It was so to-day until the fitful sunshine warmed the birds and trees, and then never was the world so beautiful. While freshets cover a good deal of ground, they uncover many a secret of the earth and air.

I found purple martins in abundance in one wooded corner of the marsh, now a lake; knowing of no martin box very near, I looked for their home, and, while not quite sure, believe they were nesting in a great gum-tree, in which I know are many hollows. Perhaps I may follow this up and make sure later in the season. But I did find the beautiful white-bellied swallows and their nests. Single pairs were occupying old, downy woodpeckers' nests in dead birches which grew in a swampy meadow that is impassable when the water is at its lowest stage. How tame they were! My boat touched the tree, while the birds clung to the entrance to the nest, or perched upon the top of the dead and limbless tree-trunk. The light, as reflected from their glossy backs, was very brilliant, and the birds, tree, and water made a beautiful picture.

There is a wide-spread impression in my own neighborhood that the white-bellied swallows 


\section{Waben Grass is Green}

were discarding their tree-nesting habits and associating with the bank-swallows. I was not surprised when I first heard the suggestion, but do not now incline to think it correct; but certainly the two species are often most intimately associated.

The marsh-wrens were all excitement and mirth. The storm could not disturb them, and their singing was as incessant as the lapping of the little waves upon the sides of the boat. They, too, were tame, and it is one of the charms of birdmusic when we feel that birds are welcoming us, and not scolding because we intrude. A tame wild-bird is one of Nature's masterpieces. Nothing else that I have ever met has given so much pleasure, and proved so suggestive.

Floating to other points, I came by chance upon a favorite corner, where birds are always found. The redstarts - miniature orioles - were there in abundance. Being so small, when half hidden in the leafy woods we may overlook them, but they showed to excellent advantage as seen in the waterscape. The land is too often a sober background with which they blend too closely; but every one of the redstarts, with the glittering sheet of water behind it, was to-day as brilliant as an oriole.

A word, before it is forgotten, of an oriole in the uplands. In full view of my front door, a splendid full-plumaged male has been busy build- 


\section{Taben Grass is Green}

ing for several days. $\mathrm{He}$ is a bird of faith, for I have seen no mate near him; and a bird of energy, for the wind gives him a deal of trouble. The unfinished nest is at the end of a long branch of a sycamore, fully forty feet from the ground, and so slender are the supporting twigs that the slightest breath of air sways them violently; yet with all this hindrance, for such it must be, the bird is tying threads and weaving strings, and at the same time, to balance himself, has to spread both wings and tail when a puff of wind threatens to turn the structure inside out. Once at least the bird has lost its temper. In stamping down the bottom of the nest-for so I interpreted the movements - one or more long strings caught in the bird's claws, and he could not shake them loose. I thought the nest would be torn to pieces, and it certainly was rather ragged and woebegone when finally the oriole was free. How he scolded! The chirps had a twang of profanity about them, and when at last he darted off, it was to a cool thicket on the hillside, where the provokingness of inanimate nature was probably the subject of his meditations. I saw the bird no more that day, but "time at last sets all things even," and the next morning the damage was cheerfully repaired.

Suddenly the scene changed, and the black clouds gathering overhead made even the open country dark; but it is no great misfortune to be 


\section{Waben Grass is Green}

caught in the rain. I sought shelter under a tall tulip-tree, and while toying with its beautiful bloom listened to the patter of rain drops on the tree's large leaves. Much has been written of the rain upon the roof, but finer music is that of the patter of rain-drops upon the leaves, and they afforded all necessary shelter, too. The wooded hillside was behind me, and a lake of a thousand acres before. Whether I looked landward or waterward, there was an embarrassment of riches, but I found the rain itself of peculiar interest. The surface of the water was unchanged. No trace of a dimple could be detected, and yet the big round drops fell with force and a steady rattle upon the foliage. Over the meadow there was but a fine mist that had to be felt to be realized.

It was at this time I noticed the drowned-out life that was floating about in most disconsolate manner. Beetles and spiders were fellow travelers on many a twig, and one poor toad was the picture of despair. Just as we associate frogs with water, so the toad belongs to dry upland, with its hot highways, where the dust is seldom laid even by the dew. But toads can swim well, if they need, and have no dread of water, but they draw the line at an involuntary bath. People have curious ideas concerning toads. They do not come down from the clouds; never believe the statement that they do, even if the narrator says he saw it. Such people see without reasoning, and what appears to 
happen is not that which does occur in the toadworld any more than in human affairs. Then we hear much of toads that have been hundreds of years in rocks and come out alive when released. Look the other way and laugh when you hear this. It might be dangerous to laugh in the narrator's face. Ispeak from experience. "Do you mean to call me a liar ?" the man asked excitedly. "No," I replied. "Well, you look as if you were doin' a mighty sight o' thinkin' in that direction." And the man was right.

Our common toad is a very quiet and most useful creature, and if not to be commended for looks, has the undoubted merit of a good voice, for I have never heard any one decry the "song" of the toad as it rings out over the meadows and along our creeks, during the evening, and often, when the days are cloudy, from morning until night. I will not attempt to describe it; let this be the reader's work during the coming summer, for work it will prove, to accurately put in print what the toad, or any frog, or even the peeping hyla says or sings. Animal voices are to be studied when the animals utter them, and there is no field work better adapted to test all our faculties than what may be called "voice-hunting," or following some one sound to its source and positively identifying the creature. Toads vary their voices somewhat, and have a knack, too, of ventriloquizing, and you may find the animal a hundred 
yards or more away from where you located it when you started on your hunt.

This is what Professor Cope says of them, and all to the contrary may be set down as false:

Dwellers in the country are familiar with the voice of this species in the early spring, which is the season of the deposit of eggs. These are laid inclosed in a long, thick-walled tube of transparent albumen, secreted by the walls of the oviducts. These tubes lie in long spiral strings in the bottoms of the ponds where they are deposited. The young hatch out early, and are of a darker color than those of others of our Salientia (frogs and toads). They retain the dark color till near the time of the completion of the metamorphosis. This takes place at an earlier date than that of the Ranæ (frogs), and the completed young are scarcely as large as those of the Hylæ (treetoads) or of the Scaphiopus (spade-foot toad). The voice of this species may be heard well into the summer. It is a sonorous ur-r-r-r-r-r, which may be readily imitated by whistling while one utters a deep-toned vocal sound expressed in the above letters. Individuals differ in the pitch of their notes, but a chorus of them has a weird sound well befitting the generally remote spots where they congregate, and the darkness of the hour. When not thus engaged, they often take up their abode beneath the doorstep of the farmer's house, and issue in the evening to secure their insect food. They progress by hops, and only walk on very rare occasions.

So far, my friend, Professor Cope; but toads are quite as abundant in villages and towns as in the country. I have seen them in the open "squares" of Philadelphia more than once, and they are not unknown in the yards of resi6* 


\section{Wuben Grass is Green}

dences in all our large cities. I have found them, too, very far from any human habitation. They are quite indifferent to the nearness or remoteness of man, and ask only for food and shelter. To me, their cry, when a number simultaneously utter it, is inexpressibly melancholy. It reminds one of the Ah me! and Heigh ho! of very old people, who are indulging in unpleasant retrospection.

I put the forlorn toad in my boat and afterward placed him on the remains of a muskrat house. This had been intact until very recently, but now the freshet was working its destruction. Placing the toad in a dry spot, I circled about the house, recalling a day last winter when I came here on foot.

The day was perfect. It has been said that the darkest hour of night is just before the dawn, and so, too, the brightest days forerun the storm. This is where weather folk-lore has kept within reason. The day was beautiful, and as the mucky meadows were smoothly covered with thick ice, I rambled all over them, forgetting the possibility of air-holes and the course of the swiftly running brook, that keeps fairly open in mid-summer, although rosemallow, pickerel weed, and lotus crowd its banks and extend into its channel. Now, as I looked across the wide expanse, there was no green thing save the dark cedars on the high ground beyond : but here and there as I looked down through the ice I could see the waving masses of utricularia or 


\section{Taben Grasz ts Green}

bladderwort, but with no tiny fishes, tadpoles, or mosquito larvæ in the utricles. I did see a poor turtle that some infra-crystic disaster had ousted from his winter quarters, and a few slowly moving fishes. Here was indeed enough to have kept me all day abroad, but I had a settled purpose when I started, and that was to visit the huge domed muskrat house, a miniature haystack, that projected nearly four feet above the ice. The occupants built it as long ago as last November, but until now I could not get very near it. It was made of short sticks and masses of frost-bitten vegetation taken directly from the marsh, and as nearly as I could determine was some ten feet in diameter at the base and about five feet high. There were no signs of the muskrats, of course, and I did not let my idle curiosity go so far as to break open the roof to catch a glimpse possibly of its tenants. Not far off were three others of these houses, but none so large.

Muskrat houses figure in folk-lore, and I have been told again and again that when they are built it means a hard winter, and vice versa. My own experience, to date, leads me to conclude that a very wet autumn and high water leads to their construction, and they are not made when the weather is warm and the marshes comparatively dry; but I doubt if there is any rule in the matter, and others who have made continued observations may have reached quite different conclusions. 


\section{Waben Grass is Green}

As this over-full May-day wore on, I began to wonder what was to be its prominent incident, for as yet I had been but pleasantly entertained, and nothing that smacked of adventure had occurred. I had not long to wait. Soon there was a violent agitation of the water in a distant meadow, and I knew that some strange creature had at last appeared upon the scene. What could it be to lash the water into a foam? Even if the sea-serpent or a giant octopus from the Atlantic, I was willing to meet it, and made my little boat fairly fly over the flooded meadows. How I fancied strange creatures and strange adventures! What wonders I was to accomplish, and yet armed only with my oars! What a fever of excitement I worked myself into-to find a dozen or more stranded carp!

It was a melancholy ending to my anticipated victory over something worthy of capture. They were sluggish and frightened fish, and of course could be readily picked up. It would be well to take one home, to show the family; but my views of the matter and those entertained by the carp seemed to differ. They neither permitted my picking them up nor offered any opportunity to be knocked senseless by an oar. They were not fools, but I felt like one. How much easier it is to measure your neighbors than to correctly estimate yourself.

Daylight ended, as usual, all too soon, but there 88 


\section{Taben Grasg is Green}

was a wealth of beauty in the brief gloaming. The dimmed light gave the meadows the appearance of a misty mirror; for the muddy waters were now at rest, except in the wake of my boat. Resting, I thought, after a tumultuous trip from the mountains, and regaining strength before journeying to the sea. So much for fancy, but there was a fact that I recalled. The quiet waters were slowly depositing the soil they had brought from the hills; lowering them and building up the tracts of pasture lands that skirt the Delaware for many miles.

\section{II}

UNDER no other circumstances can the outdoor naturalist see so much and so satisfactorily as when in a boat; not some puffing, crowded public affair, that plies up and down the river, but when alone in a row-boat of his own. I say "little," for the smaller the better, as the best things in the matter of wild-life are so apt to be in the half-hidden inflowing brooks and vine-embowered bays that have scarcely any inlet from the main stream. These inland creeks are all treasure houses to the naturalist, though barren wastes to those unfortunate people who have no taste for the scattered remnants of the world still left as nature designed them.

Those who have ever reversed a spy-glass, and made near-by objects look as if a mile distant, 89 


\section{roben Grass is Green}

have much these same conditions when standing on the creek's bank and looking over the water. Then, all the world's out of reach; but in a boat every object is close at hand, and there is very little that escapes us. Another important fact is that wild life is less timid when we are sitting in a boat, and permits nearer approach than when we attempt to draw close by walking or creeping. A boat is the naturalist's third hand, and better than all the legs of a centipede.

I left the landing while the day was young, leaving to chance what port I should make, trusting any point at which I should touch would prove a snug harbor. The tide was running out, so I started up-stream, pulling against the current while my arms were fresh, but before going many rods it seemed all unnecessary, and I said: Why not here? Why hurry past this tree and that meadow for those that are next to them? Bottle the mud on the Smith and Jones farms, and no one is the wiser, if the labels are changed. If we measure a mile by its objects of interest, few men have ever traveled so far.

I stopped rowing and commenced looking. There were long and narrow avenues up the weedy marshes, and here and there a track of a meadow mouse that had come down at low tide to the creek's edge. Under the water, these tracks were still plainly visible, and many were centered about the half-decayed bloom stalks of the beautiful 


\section{Waben Grass is Green}

goldenclub. This plant made a superb show early in the spring, and, being one of those cultivated by the Indians, has for me an added interest. There may have been in their day some method of cooking the root that we white folks cannot guess, but the goldenclub is a failure in modern kitchens.

What an endless procession of strange living forms pass by, when we gaze into the still waters of a remote creek! I say "remote," for the stream that has a factory on its banks has too often nothing in its waters. Here, where I am afloat to-day, manufacturing has not reached. There is a sawmill a mile or more away, but no saw-dust clogs the current here, and the more distant grist-mill only asks aid of the water, and does not repay its kindness with a flood of filth. Indeed, about the old saw-mill the fish love to congregate, and at the foot of the race-way the troubled waters are often glittering with the silvery fins of a minnow that shines like metal. But here, with marshy meadows and a swampy forest to hem me in, the creek has greater attractions.

Here comes a mud-turtle. As we look upon motion, this creature is clumsy, but it does not find itself hampered by awkwardness when there is reason for agility. Its paddle-like feet can do excellent service when the animal desires to swim, and how the mud flies when it sees fit to dig. To be sure the mud is very soft in the bed of the creek, 


\section{Waben Grass is Green}

but the turtle often has occasion to suddenly disappear; and, too, without roiling the water or leaving much of a trace of its whereabouts. In all this, it succeeds admirably ; so completely, indeed, that unsuspecting prey is often seized and given just enough time to wonder what had captured it. This particular turtle scattered a great host of little minnows, not attempting to catch any of them, but looking for what matter of food had attracted them. So, at least, I interpreted its purposes. Finding nothing, it started off and met another, not of its kind, but a turtle that has the merit of gay decoration, and so is known as the painted one. These two creatures looked intently at each other as if they questioned each other's right to be there, and, human-like, I hoped for a fight, and was disappointed. It is not always so. The huge 'snappers occasionally get into a row, and there is a grand commotion. I have known battles commenced under water to be continued on land.

The water turtles probably are not as long-lived as the quaint box tortoise of the upland fields. Some years ago I found one that I knew was over sixty years old, and since then have had given me the particulars of another instance where a turtle, marked in 1812 , was in the possession of a grandson of the man who marked it; the animal being alive and about as active as half a century ago. The snapping turtle, of course, grows to be very 


\section{Taben Grass is Green}

old, but we have no chance of determining its rate of growth.

The turtle-bones in Indian refuse-heaps suggest, however, that some of the smaller species of water turtles were of larger growth some centuries ago than we now find them. Probably they were less persecuted, for the number of species that now do duty as Baltimore terrapin, unknown to the patrons of restaurants, is very considerable.

The aquatic chelonians, as the naturalists call them, recalled a patriarchal box tortoise that I recently came across. A close inspection proved him to be no very slow coach, after all. I watched every movement as he crawled by me, and he progressed, I found, at the rate of nine feet per minute, stopping frequently to take observations. This is at the rate of a mile in less than ten hours, and what may not be seen in the most commonplace mile? How closely this tortoise scanned his surroundings!

I followed in a very few minutes and found him still traveling in a direct course, and was just in time to witness a funny scene. The steep bank of a deep ditch had been reached and the tortoise was contemplating the outlook. It was too abrupt a descent for ordinary crawling, and to go in search of a more easy crossing seems not to have been thought of. At last, leaning over the edge as far as possible, the creature withdrew into his shell and sent himself, by a sudden push with his hind 
feet, head over heels down the incline and landed on his back. Recovering from the shock, if there was one, there followed a struggle to place the roof of his house skyward, and, this accomplished, the tortoise carefully surveyed his new surroundings. I wondered if he had a sense of direction, or would attempt to climb the bank he had just tumbled over. There was some hesitation, or what appeared such, as if the tortoise was studying the matter, and then it began to climb the bank, which was less precipitous, directly opposite where he had fallen over. Was this accidental or intentional ? I think the latter. The whole manner of the tortoise seemed to indicate it, and it certainly had one guide, its own traces, where it descended to the bottom of the ditch. We know so little of the mind-power of the lower animals that it is always difficult to demonstrate anything conclusively, and, unfortunately for the good of compararive psychology, the eager out-door naturalist is only too apt to overestimate the mental capabilities of wild life. I thought, too, at the time, what a happy way to cross our lives' deep ditches, if we could but put it in practice. Shut ourselves within ourselves, roll over, and trust to luck. But how few have sufficient confidence to do this. Half our lives we tremble on the bank of a dry ditch and then turn back in despair.

To lean over the side of the boat and peer into the depths does not prove tiresome. There is al- 


\section{Wuben Grasg is Green}

ways a changing scene, and when one form of life passes on another is pretty sure to promptly take its place. When the fishes do not flash by, perhaps a mussel will come slowly creeping along, and how very few people have ever seen this "shell," as they call it, deliberately pick itself up and take a walk. It leaves a well-defined track behind it.

Something fierce enough in appearance to make you draw back, if it rushed suddenly toward you, is the giant water-bug. It is boat-shaped, some three inches long and looks as fierce as it really is. They feed not only upon other insects, but fasten themselves to fishes of considerable size and literally worry their lives out: an animal of no importance destroying one of value; something we see going on all the time, but I suppose giant water-bugs have their right to live, even their mean, tyrannical lives. We cannot but admire their agility, however, and this is their single merit. They have the knack, like some people, of gaining the applause of the gaping crowd, of being admired by silliness, but, never heless, despised by common sense.

But what of the land near-by? My neck did grow a little stiff looking in one direction so long, and I glanced over the meadows for a change. The blackberry thickets were all abloom, looking like lingering snow-banks, and what a concert among the birds! I heard a dozen distinct spe- 


\section{Waben Grass is Green}

cies singing at once. Of course the trained musician would have shuddered and talked of discord, but I am willing to take all such sounds as they come, and extract their sweets when there is a chance to recall them; but still I do wish the great crested flycatcher were mute, and the robins a little less noisy. These latter are so like tiresome people we meet, who are heard the more the less they have to say. Conceited people never admit that silence is golden.

The prominent birds of the landscape, just as I looked up, were those beautiful little finches, the indigo birds. There were five in full view, and every one was singing. I recognized them entirely by their voices, for look as I would, from this point and that, I could detect no blue color. It often happens that what we would say were conspicuously colored birds, such as this one and the cardinal red-bird, are really plain and blend with their surroundings. It is, I think, the yellow and white or the jetty black birds that can never be mistaken. Has the red or blue feather a trick of so turning in the sunlight that its brilliancy is lost? I have seen a redbird look black as ink, and the bluebird as dingy as a sparrow.

There is excellent opportunity for original work in this study of animal coloration. Much has been done, it is true, but then the authors who have treated of the subject have not come to quite the same conclusions. This is good reason for the 96 


\section{waben Grass ts Green}

young naturalist making his own observations and reaching his own conclusions. I have long believed that fish and some batrachians have this matter of their color under control, but careful experiments by others contradict this; still I am not convinced, and it is this room for suggestion that gives such zest to natural history studies.

\section{III}

I HAVE sometimes wondered what Thoreau would have had to say had barbed-wire fences been run here and there through Walden woods. We know what a picture is before us whenever he mentions, however briefly, a New England stone fence.

This villainous invention is everywhere about me, and probably nothing is so fatal to a rambler's enthusiasm as to leave bits of his clothing and an occasional drop of blood on a jagged wire, when just starting out for the day, at four o'clock in the morning. But why not wait until broad daylight, when even the woods are no longer dark? I have been asked this silly question scores of times, and my answer has been short and sharp as the barbed wire- "fool." If the dawn has features all its own, it is my business to be astir that early, as I want to know the day's whole history. In this case the whole loaf is eminently to be preferred, desirable as half a loaf may be.

The principal reason why so few people see much 


\section{Taben Grags is Green}

that is going on about them is because they are only present at the finish, and abed at the start. Wild life is indifferent whether mankind sees it or not; or takes care that it shall not be seen. The beast and bird have a preference for sunrise over high noon, and for moonlight over sunshine, and take no pains to inform their arch-enemy that such is the fact. I learned the truth by accident, and so mean to be abroad, whensoever I choose, as early as the dawn; and when I can I will cut the wire fences whenever they cut me. More than one man blames his bull, or some loafer, and I have the added labor of keeping a straight face.

If too early, the most that you can do is to wait, but too late can never be remedied. I was not too early, though it was not light. The clouds in the east shut off the rosy dawn that I had wished to see, but near objects were not obscured. I have mentioned an oriole who made for himself a nest under many difficulties. His troubles have not yet ceased. The storm beat his home so badly that no mate would share it with him, and now a pair of king-birds have located near by, and are trying to steal the material of the oriole's nest for one of their own. They do not succeed very well. The materials are too closely interwoven, and no amount of tugging at them seems to damage the nest as a whole; and then the oriole objects. In the dim light I saw a battle between the king-birds and the owner of the abandoned nest. 
It was more than a "scrimmage." Much screaming and shrill alarms, it is true, but blows were freely dealt, and the king-birds were worsted. Then what a song of victory on the oriole's part! I thought I knew its vocal powers well. It has often roused me from coveted sleep in the early morning, but to-day it would have waked the seven sleepers had they been in the township. This before sunrise, and I hoped the battle had been a decisive one, but it proved not, and many equally voluble and sanguinary were fought throughout the day. Perhaps not sanguinary, but feathers flew, if no blood was spilt.

Troubles of this kind among nesting birds are not usual. Widely different species are amicably disposed, so far as my observation goes, while nest building proceeds. In the lane, lined with old apple-trees and maples, there are now nesting the great crested flycatcher, the robin, the house-wren, the chipping sparrow, the cat-bird, the warbling vireo, the purple grakle and English sparrow; while in a brush-heap very near are a pair of brown thrushes, and an indigo finch has located in a blackberry brier. These birds are constantly associated, and $I$ have not seen the slightest evidence of a conflict of interests. Other birds, nesting in the nearby woods, are continually coming and going, and there is seldom a moment when some one, two, or three are not singing, but none appear to scold or even utter an alarm note. 


\section{Taben Grasg is Green}

And how very tame will some birds become, that are not usually found near our houses. We expect the wren and song-sparrow to show little fear; but during the present summer I was able to make friends with a redstart and a wood pewee. I have a settee placed on the very edge of the plateau so that I can see all the meadows below, and along the hillside at the same time. It is an ideal spot for a seat and my favorite resting-place. Directly in front is a cedar, and to my right, as I face the meadows, an oak. On the former there is a redstart's nest, and the pewee's nest is on the latter. At all times of day the birds are busy flycatching, and soon learned to regard me with perfect indifference. When the redstart began to build, there was some fluffy material very near the settee, and it had appropriated some of it when I happened to commence my visits to the spot. It was disconcerted by my presence at first, but as I sat perfectly still, it made a trial trip, and finding I did not move, gained confidence; and all the season through, this redstart (the female was more shy) paid no more attention to me than to the trees and bushes about me. It frequently went so far as to alight on one end of the settee while I was sitting at the other.

The nest of the wood pewee was rather farther away, but the bird's favorite perch was directly opposite where I usually sat. As I did not drive away the flies, the bird was not annoyed and soon ac- 


\section{Waben Grass is Green}

cepted my presence as a matter of course. Many a time it flew so near to my face and snapped its beak so close to my ears that I involuntarily drew back my head. I think it came to recognize or distinguish me from other people. A word more concerning this pewee. It detested tobacco smoke, and moved to a more distant perch if the wind carried the smoke from my pipe to where it usually sat. While, for night after night, I watched this bird, I kept track of the movements of others, and found that the pewee stayed up later and sang longer than even the robin. It continued flycatching when the gloaming was well nigh past, and showed a power of sight approaching that of an owl.

In the woods at sunrise! How very different the same spots appear at the different grand divisions of the day - sunrise, noon, sunset, and midnight! There are few people, comparatively, who know anything of the first and last of these four divisions, and yet there is more to be seen and heard at sunrise than at any other hour. Generally so, I mean; for the character of the weather each day has much to do with it. A steady, allday rain makes the whole twenty-four hours painfully monotonous, but not so of a typical June day, with a misty sunrise; a clear, furnace-heated noon; a red sunset, and a starry night. We had such yesterday, and to-day tells the same story. Wild life finds no drawbacks, and what happened when 
the country was young and fresh happened again. The sights and sounds that caught the Indian's attention before Penn landed held me to-day, as I stood under the intertwined branches of the old oaks, through which the sunlight struggled almost in vain. Song after song came from far and near, and every trace of harshness was strained out by the leaves, the dew-drops, and the flitting sunbeams. Here is the great merit of the early morning - freshness; and we too are well awake, and every sense is receptive. The birds grew merrier steadily, and I wondered what species uttered some unfamiliar note, in more than one instance. I could but guess, and fancied that there were early morning notes that no one ever heard at noontide. Until we reach the truth by accident it is better to conjecture than to slaughter birds to ascertain a fact without which we can survive and be happy. I do not believe that ornithologist would be content who had fathomed every mystery of the birdworld. Better to be forever wondering what this and that signifies, and pass your days in hopes of discovery. That something new may turn up adds a zest to every morning walk, noontide meditation, or evening stroll.

But it is raining! My pleasant train of thought was sadly shocked to hear the patter of rain-drops on the broad oak leaves. Raining undoubtedly, and yet there is sunshine in the open fields. How prone we are to jump at conclusions. I was not 


\section{Taben Grass ts Green}

standing under an oak but under a wild cherrytree, and it was raining down the immature fruit that rattled wherever it struck like rain-drops upon leaves. Had I been in my tent and half asleep, how readily would I have insisted that we had a shower in the night. The imagination makes sport of us, at times, when we pose as interpreters of nature. This may not please us, when its victims, but what opportunity it affords to criticize our neighbors.

Birds, like men, give way to business as the day waxes old, and now, although early, the chirp of occupation took the place of the thanksgiving song, and the cat-bird whined because the day was already hot. One little white-eyed greenlet tried to forget it was warm, and worked itself into a fever with overmuch reiteration. So, too, the redstarts felt that they must sing the death-song of every fly they swallowed; but the music proper of the day was done.

It is Thoreau, I think, who, in "Walden," records :

The Harivansa says : "An abode without birds is like a meat without seasoning." Such was not my abode, for I found myself suddenly neighbor to the birds; not by having imprisoned one, but having caged myself near them. I was not only nearer to some of those which commonly frequent the garden and the orchard, but to those wilder and more thrilling songsters of the forest which never, or rarely, serenade a villager - the wood-thrush, the veery, the scarlet tanager, the field sparrow, the whippoorwill, and many others. 


\section{Waben Grass is Green}

Such, I am happy to say, is not my abode also. All the birds Thoreau mentions, except the "veery," are my near neighbors, and others that do not go to Massachusetts are here also, prominently the crested tit and Carolina wren. Then, too, I have three pairs of cardinal redbirds near, and a little heronry within sight. What music from dawn to dark! I do not think five consecutive minutes pass that at least one bird cannot be heard, and far oftener three or four. Even the little green herons that are nesting in the "pondhole," a sink-hole in an upland field, squawk as they fly over, and such harsh sounds are pleasing, coming from such a source. To those who have long been familiar with birds, it is a merit of their songs that, however humble, they bring up a pleasing picture, recall a thrilling adventure, and bring back days gone by that teemed with pleasure. Doubtless a too frequent repetition of any bird's song, if the creature were caged, would become monotonous, but what of the association of song and scene; of song-sparrows and the old garden; of the wren's vehement twitter and the old birdhouse on the arbor? These were the prominent features of wild life that excited my wonder when a child, and to hear them now is to renew one's youth. Is it not strange so little attention is paid to the modest wants of our native birds, and yet we continually hear the regret that the birds are not as abundant as formerly. I used to think so too, but a little care in protecting them was all that 


\section{Waben Grass $\mathfrak{i s}$ Green}

was needed, and now the whole farm is an aviary. If I have any fault to find it is that to listen to. any one bird is difficult, so many are singing.

We hear the complaint now that there are no bluebirds; and even the suggestion is made that they may be becoming extinct. But what can we expect? The blizzards are blamed, but the fault is largely at our own doors. Who takes the trouble to kill the pestiferous sparrows and allow the bluebirds undisturbed possession of available nestingplaces? And how seldom is the child reproved who climbs to the hollow in the old apple-tree "just to look in," as he says. The birds are frightened and perhaps make no other attempt at nesting. Blue-birds are not extinct, although I have not seen one during the present summer. There is a colony of them on an island in the river, where they are not worried by imported pests. What is needed is a vigorous enforcement of existing laws, and additional penalties upon those who go about seeking what they may destroy, as "collectors." The landowners are now at a great disadvantage. If they shoot "collectors" as they would mad dogs and destructive ver$\mathrm{min}$, it is sure to give rise to no end of trouble, to avoid which, the farmer must give up the useful as well as ornamental birds upon his place. The law is rotten, through and through.

The chirp of crickets in the weeds by the old worm-fence was now the prevailing sound, and the rustling of the dead leaves where a snapping-turtle 


\section{Taben Grags $\mathfrak{i s}$ Green}

was making her way to the plowed field close at hand commanded my attention.

How little this cross old dragon thought that her eggs would make me an excellent meal; for there was scarcely a trace of anger in her eyes as she passed by. Later I found her nest, and the twenty-one fresh eggs neatly tucked away, a foot deep in the earth, were confiscated.

How strangely and yet not unwelcome sounds a breakfast bell in the woods; for I was " in the woods," and could see no trace of habitation or civilization from where I stood. But sound has many a highway not even a bird can travel. The bell brought many a prosy thought to mind, and trees and birds and flowers and stones made up a strange world that I was willing to forget, that I might have my breakfast. There is a limit to one's enthusiasm, after all ; and strawberry short-cake is not an altogether poor exchange for the world from which the berries and the flour came.

Out at four and back by eight o'clock! My labors, if I so elect, are over for the day, and I may rest, if I will, while others bear the heat and burden of the later hours.

\section{IV}

SOMEWHere in Thoreau's " Maine Woods" will be found the following sentence: "He who rides and keeps the beaten track studies the fences chiefly." ro6 


\section{Taben Grass is Green}

And how desperately forlorn, forsaken and repelling are the great majority of our country roads. We hear much, of late, of making them better for wagon traffic; but how little has been said of beautifying the highways? and never a word for the foot passenger, as if he who has no horse is beneath consideration.

There is so generally nothing to see on a highway, as Thoreau intimates, it is necessary to jump over the fence, trusting you will not be held for trespass. I leaped a fence recently into an unknown field and alighted on a snake. Fortunately the astonished reptile was not injured, and I took it up carefully, much to its disgust; but it was pacified at last, and we had great fun. Of course it bit me several times, but then got tired in both neck and jaws, and it was my turn. I puffed tobacco smoke in its face, and how it struggled to get free. Then I put it down and ranafter it, when it would coil quickly and "play" mad, but it soon saw I was only in fun, and was really docile. It was a striped garter-snake, twenty-nine inches long, and being newly dressed, that is, having recently shed its skin, was really handsome.

How utterly unreasonable it is to be afraid of snakes. There is not one chance in a thousand of encountering a rattlesnakeor copperheadin our ordinary rambles, and there ought to be a reasonable probability in every half-mile walk of seeing a greensnake, gentle, harmless, and beautiful; a garter- 


\section{Waben Grass ts Green}

snake, that will run away, if it has a chance, or a puffing-snake, that will make a great show of fighting, but like many people is a mere blusterer. It is one of the entertaining sights in nature to see a huge black-snake glide like lightning through a thicket of greenbrier.

A word more of this same black-snake. It is a harmless creature. Do not believe one syllable of the newspaper stories about their attacking children. They are falsehoods as black as the creature of which I write. We should remember that the so-called balance of nature is necessarily disturbed by men's interference. Clearing and cultivating land is, in a sense, unnatural, and the more this interference is carried on, the more difficult it becomes to prevent an undue proportion of such forms of life as are least affected by the changes wrought by man. Now, the food of the larger snakes is very largely mice, and that of the smaller ones grasshoppers and other large insects, and insect-larvæ or grubs. The farmer knows only too well the destructiveness of mice and insects, and yet allows the natural enemies of these to be destroyed whenever found. Snakes should be encouraged. They do nothing but good, except an occasional bird's nest destroyed - and the silly nonsense handed from parent to child concerning them should be heard no more.

But having jumped the fence and found a snake, I was not disposed to conclude therewith the day's 108 
outing, but kept on my way, ready for new adventures or a repetition of some old experience. I was not disappointed. Crossing a field that was well sprinkled with bits of Indian pottery, and so in old times an Indian village site, I came to a pretty brook, well lined with tall trees on each bank.

A babbling brook

In a shady nook,

With charm none may resist,

Where the prying sun,

Ere his course was run,

The rippling waters kissed.

I looked for little fishes, silvery minnows or speckled darters, but found none. From under one flat stone there darted something that might have been a baby red-fin. I was disappointed, and then recalled how foolish was such a feeling. As if there were no other creatures but fishes in and about a brook.

I once made, or undertook to make, an annotated catalogue of a meadow ditch, but gave up in despair. I never saw a brook, whether a mountain stream or a lowland water course, that was not a museum. There are turtles, snakes, frogs, and generally the miscalled water lizards, that is, salamanders. Perhaps no one of these forms is quite as attractive as a lively fish ; but it is a great mistake to withhold attention because our first impressions are not favorable. Seeing the creature, stop always to determine what it is about, whether 


\section{Wolben Grass is Green}

it is moving or still. Remember it has a purpose, and it is the naturalist's business to determine what it is.

Fish or no fish, teeming or empty waters, it was a beautiful place, and I had scarcely taken a seat in a cosy nook than a rose-breasted grosbeak began singing. It is an entrancing song, rivaling any of our thrushes' best efforts ; then a mourning dove dolorously held forth. This was provoking, but how like human experiences generally. Sadness casts so great a shadow in the world, gaiety forever trails her skirts within it. Then a blinking frog popped his head above the water, and gave one loud, deep-toned grunt and disappeared. Did he too express his disapproval of the dove's complaining. To me it seemed so, and I laughed aloud. This broke the spell, and all the doves in creation could not have given me the blues. The grosbeak still sang at short intervals, and, when he did not, that marvel of restless energy, the Carolina wren, broke in with a shrill "keep it up, keep it up, pitch in, jolly!" Truly, of a bright May day the dove is out of place. My merry-making friends passed by, and that common scold, the crested flycatcher, took their place. It was a terrible come-down from the sublime to the ridiculous. Why it should ever attempt to sing or even to speak with such a voice is a hard problem to solve. That such discordant utterance can be of any use is hard to imagine. It sounds like a scoid- 


\section{Talben Grass $\mathfrak{t s}$ Green}

ing or ill-natured fretting aimed at the world at large, but no bird seems to pay any attention to it.

Where do these birds find the snake skins that adorn their nests? A shed skin is not a common object, likely to be seen in our rambles. I have found very few of them; yet until recently I never found the nest of this bird without one or more. What sharp eyes the birds must have, or do they know just where to look? Then again, why do they use them? If we could only go back a few thousands of years and see what bird-life was in pre-glacial times, what a flood of light would be thrown on the bird-mysteries of to-day. Probably a good deal that we notice now is but survivals of habits that had meaning when they originated; just as there are many such survivals in human customs.

Having dropped out of the procession and not likely soon to rejoin it, now that I was so comfortably fixed, I fell to wondering what was the most interesting form of life that I had seen; and a more unprofitable subject never engaged attention. To him or her who knows how to ramble, how to see, how to interpret, this making of distinctions between one form and another, this having preferences which lead to prejudice, will not occur. The insect that slowly crawls across your sleeve may be to many but a mere speck, but look at it through a good lens and what a marvel of beauty and intricate anatomy it proves to be! 


\section{Wuben Grass is Green}

Nothing to most of us can be more monotonous than the ceaseless and seemingly senseless whirling and twirling of the shining black scuttle-bugs or whirligig beetles that are as familiar "as the gurgling brook or the flecks of foam on its 'golden-braided center,' or the trailing ferns and rustling rushes on its banks," but have you ever caught one and noticed that it has two sets of eyes, so as to look into the water and out into the air? You have always seen them skurrying on the surface; did you ever see them dive or fly to another brook or pond? Do you know they smell like rotten apples? Do you know there are twenty-seven kinds of whirligig beetles? Which one is yours?

For half a day I was one with the wild life about me, and when I returned to the haunts of men the savage in me was not apparent to others, but made them, to me, look less noble than they appeared to themselves. There is many a lesson that wild life can teach us, which, if we are willing scholars, will prove greatly to our advantage.

\section{V}

LiqueFy brass by heat and then reduce the liquid to a yellow gas, and you will have what did duty for atmosphere at high noon recently. It was $95^{\circ}$ in the shade, on the north porch, and away above $100^{\circ}$ out in the fields. For this reason 


\section{Wuben Grags is Green}

I took to the fields, and finding only crickets equal to the occasion, kept on, and soon plunged into a ferny thicket with three big oaks and a bubbling spring. Here the thermometer showed but $88^{\circ}$, so I had found a cool spot and concluded to tarry. It was all very well to let enthusiasm suggest examining the animal life of a field at noon, but to carry out such suggestions does not pay for the danger involved. It was hot enough to melt your brain, and I shall never forget the languid look of one poor toad that by some cause had been ousted from his day-time retreat and found it too hot to go hunt up another. That toad would not hop, but let me roll him over with the toe of my shoe. The rattling creak of the crickets sounded precisely like the crisp crackling of dry twigs in a fire. What is to be known of open fields at mid-day in summer, let others tell me.

But the spring, oaks, green grass, and ferns: these told a different story. Of course the birds objected to my intrusion, but soon were reconciled. I sat down and made no demonstrations that would excite alarm. Curiosity, common to birds as man, was soon the uppermost feeling, and I was entertained from the start by a cat-bird, a red-eyed vireo, a chewink, a yellow-breasted chat and a pair of song-sparrows. Curiosity was uppermost in them all, and it was quite evident they were not accustomed to a permanent intruder. I will not venture to say how near the cat-bird came, 


\section{Troben Grasg is Green}

because the whole truth in bird stories is too much for the average reader; but I was interested in testing their fearlessness and intelligence, so, after sitting perfectly still, but watching them by movements of the head, I changed my tactics and pretended to be asleep, keeping an eye open. The bird was puzzled at first, and seemed annoyed not to be able to fathom the mystery. Nearer and nearer it came, and when I thought it had reached the extent of its daring, I gave a sudden start. The cat-bird gave as sudden a squeak, and I saw it no more.

Up to this time, the other birds I have mentioned were more concerned with their own affairs than with me, but the cat-bird episode drew their attention more closely to my presence, and I found myself literally the observed of all observers. The vireo, never ceasing to sing, and the sparrows kept overhead, the chewink close to the ground, and the chat darted hither and thither, ventriloquizing splendidly, and so making itself appear everywhere but where it really was. The conditions were interesting, but I could get nothing out of it, I being the caged animal and the birds the spectators. I changed my position and got near enough the spring to lean over and drink from it had I chosen. This changed the whole status of affairs. I had almost sat upon the chewink's nest, and what a racket was sounded. Never did birds chirp more loudly, and the chewink now got 


\section{raben Grass is Green}

directly overhead and began a piteous appeal. The birds from all about (except the cat-bird) through sympathy joined in, and I was soundly berated. I moved again, but the birds followed, and promised me no peace while I remained under the oaks. It was too hot to leave altogether, and I prepared for a real nap, but this was impracticable. Over and above the loudest chirps was heard an ominous humming as of swarming bees, and looking upward I saw not bees, but a cloud of mosquitoes. As a puff of smoke they had suddenly appeared, and the branches of the oaks had caught them.

Was I to run for dear life over those hot fields? I sat very still, but never took my eyes from the cloud in the branches. There they seemed contented to remain, and the birds flitted about beneath them, but not even the vireo disturbed them. So long as they kept above I enjoyed their presence. It was something novel; but this was not to be continued. I moved to get a drink; the birds renewed their clatter, and down the cloud came. I darted into the open, and used my hat for a brush, escaping any harm; but the warmth of that mid-day run! The grass was brittle; the ground, an oven floor; and the breeze that passed by, the breath of a furnace. When I did stop, to my surprise, an indigo bird flew to the fence post and sang as cheerfully as though it was after sunset.

It is not a pleasant thought that man, who 


\section{Wuben Grass is Green}

prides himself as the head of creation, should be so very weak and helpless in fact when attacked by the lower forms of life. His wonderful powers do not avail much when there are mosquitoes on the inside of the window screen. Here I was, in a hot field, in danger almost of sunstroke, with a haven of rest in full view, and yet I dare not enter it, because of a swarm of mosquitoes. It was very provoking, to say the least, and I rather concluded that man lives not because nature is favorable to his needs, but really in spite of her. While thus musing and about to take another start for home, a little breeze sprang up, and I could see the mosquito cloud again in the air, so I again ventured to the three oaks and found the coast clear. Drinking cautiously of the cool waters I was again ready for the birds, but where were they? I waited and waited, but there was no sound, except that of the trickling waters, and the creaking of the field crickets in the open. I tried an old plan, that of squeaking like a young bird, and this succeeded. One by one the birds came back, and looked at me as before; looked and scolded. It was very tiresome, but it was too hot to plan new adventures. If I stayed, I must put up with it. But why had the birds absented themselves at my second coming? Was it a plan on their part to deceive me, thinking I would go away if they were not present.

This implies that birds have language, and birds II6 


\section{Waben Grass is Green}

of different species can interchange thought. That a sparrow should communicate by sound or sign to another of its kind is nothing strange, but there are some difficulties in the way when we suppose a cat-bird talking to chat or chewink; but this seems to be the truth, at all events. A few birds in a quiet nook, having no conflicting interests, might readily develop a simple sign language that would meet their needs. I looked for the chewink's nest, but could not find it ; but the bird interpreted my actions and so too did the others who were not personally interested, and every one of four species came, as best they could, to the rescue. I respected their feelings and withdrew, but where was the cat-bird, bravest of all at the outset. I could not see him, but just as I was leaving for home I heard a faint feline cry, and thought it must mean an explanation to the other birds, it was so pitiful and apologetic.

But why should we be forever on the lookout for bird-life in some form, when out of doors? Is there no merit in a mammal, or charm in insect life? I can recall a pleasant day, not long ago, when I was entertained wholly by plant life.

Crossing a wide meadow at noon-tide, I was glad to reach a huge hickory tree that stood quite alone, yet within sight of a little forest, and on the other side, the broad, shallow channel of the river. It was early in May, and the leaves were young, but the grass was green, the flowers bright, and no- 


\section{Taben Grass is Green}

where in the wide landscape was there evidence of anything but youthful, active life. For the new leaves upon the wooded hillside make the old hills and gnarly oaks new again. Why, I cannot tell, but as I rested in the hickories, I heard no birds and saw no butterflies; and for a brief moment was alone with plant-life. I sat upon the mossy root of the tree, and noticed, by mere chance, that the bark far above the ground was green; clothed with a growth that would have needed a microscope to detect it, had it not been present in untold millions of individual plants. A single one is little more than a single cell, with an infinitely small trace of the green that nature is so lavish with when she carpets the meadow and clothes the mountainside. All the chlorophyl in a handful of these cells on the tree's bark would not color more than one blade of grass; and yet the insignificant growth is a plant as well as the hickory that towers just eighty-two feet above me. What a world of variety between the mould on damp bricks and the trees! But wide apart as they are, there is no break in the chain from the one to the other. The meadow was very uniform in appearance as I carelessly glanced over it, wondering what had become of the birds; but how common it is to get an erroneous impression by contenting ourselves with careless glances. Nature never rewards a languid interest in her.

What I called a "grassy" meadow was in truth II 8 


\section{Taben Grass is Green}

a weedy wilderness. This was very plain when I took the trouble to scan my surroundings a little more closely. There were pale blue flowers in great abundance, the Houstonia of the botanists, and pale spring beauties, pink and white; and just beyond, nodding in the light breeze, dog-toothed violets, a lily in fact, and over the hedge there is a ruddy glow that I knew to be phlox. Here we have half the colors of the rainbow, and yet talk glibly of the green meadows, as if the red rose and white lily were myths. But what of the growths between the green stain upon the hickory's bark, the flowers, and a perfect tree? I do not know how many distinct forms of plant-life there are in the world; it is immaterial. I do know that there is a gratifying variety in this essentially commonplace corner of a monotonous region; a variety that gives us blossoms, green leaves, and queer growths for nine months of the year, and provides us in midwinter with a series of plant skeletons that are as delicate, intricate, symmetrical, and beautiful as the orchids, of which strange plants, one, a huge purple affair, is now in bloom in the little woods near by. If a single tree and its surroundings become tiresome, which I do not admit, what of the little woods just mentioned? Every tree in it is a grandchild. That is, it is a third growth, or the second since the primeval forest was felled by the first white settlers of this region. An over-practical folk, they had no ideas beyond dollars, and left no trace of the origi- 


\section{Waben Grass is Green}

nal grandeur that was convertible into cash, excepting, of course, the oaks in the meeting-house yards, and those owe their existence to the fact that they were almost if not quite a necessity. But it is scarcely worth the while to scold about our predecessors, when we are doing so little to preserve what remains of our forests. But this, my little woods, near by - it contains good examples of nine species of deciduous trees and four evergreens. All are fairly thrifty, and yet one, the sour gum, has a grievous burden to bear, in the unsightly misletoe that crowds its outer branches. What a strange freak is this! A thrifty growth of itself, it is unfitted for any condition but that of a parasite, and must have the life-blood of another to sustain its own existence. We associate in literature the misletoe and the oak, but here, except occasionally, on an apple tree, I find it only on the tupelo or sour gum. Why this preference, is a problem past finding out.

At all times of the year, it is pleasant to be among trees, whether few or many. It is such an absolute change from the open country. The first impression we get upon entering a forest is that of its silence. The effect may be depressing at first, but this quickly gives way to wonderment. The moment we ask ourselves the reason of any condition we meet, we have taken the first step toward rational enjoyment. Curiosity, that leads us into many a scrape in town, is an excellent companion 
when in the woods. Why are forests so apt to be silent? Primarily, because they are comparatively uninhabited as compared with the more open country. ( $\mathrm{I}$ am speaking of the woodland tracts of to-day. When the country was all forested, the immediate banks of streams and lakes attracted the greater portion of wild-life.) The few strictly wood-birds are not noisy species, and open-country-birds, when in the woods, are not so given to singing as when they can see in every direction and have the sun shining directly upon them. Mammals that lurk in the forest are usually silent and sleep by day, and wander forth and out of the woods by night. I have often walked a mile in a dense woods, and heard only the hiss of a snake, the hum of insects, or the rattle of loose bark over which a lizard swiftly darted. A light breeze may rustle the leaves, a sudden gustmay cause touching branches to creak, and in "the pines" we have ever "that magic tone awakened by the wind alone." But all such sounds but intensify the silence. We long for a sound from the throat of a living creature, and at last we hear it. Then, how alert is every sense! The possibly timid wanderer becomes an explorer, and we have reached the flood tide of enjoyment in a forest. Some strange bird or beast has uttered a cry, and we would know what manner of creature it was. I know of no greater pleasure than that of solving such mysteries. To follow a sound through the 


\section{Taben Grass is Green}

woods is hunting par excellence, and the game we bag, if we do bag it, has not yielded up its little life to satisfy our whim. It is not unlikely the sound heard was that of a bird, and of some very small bird at that, but the distinctness of the utterance suggests larger game. A song, for instance, that if heard in the open fields would be scarcely noticed, here in the woods fairly fills the air, and is even echoed and re-echoed down the leafy aisles. We are not alone after all, and with this pleasing thought we go deeper and deeper into the forest. Every sensation is intensified as we progress. Constant expectation renders us more bold, and if we turn a corner suddenly and find an owl staring us in the face, or a grouse goes booming away from our feet, we are not startled, but thrilled with a healthy excitement.

There is a road through the woods, seldom used and so should be grassy, but the ruts are lined with sun-dews instead: grass-like, in a general way, but with club-head or shepherd's crook endings; but what mischief they are up to when small insects come their way. The glistening freshness is sweetened even that it may be more tempting, and woe to the fly that stops to take a sip. It is not only caught but eaten! Not all plants are content with air and water for a food supply. These sun-dews are carnivorous, and so is their cousin, the fly-trap, that grows in North Carolina; but we need not travel so far to find 


\section{Taben Grass is Green}

these flesh-eating plants. The side-saddle flower, that is a thrifty growth by the pond-side, has an elaborate trap for flies, and even for the young salamanders that have been found venturing up their sides - or was it accidental ? - and in the water of many a brook and pond the bladderworts catch fish and eat them. Curious this may all be, but it is a bit depressing after all, death figures so prominently, and life is the keynote of a bright May morning. Glancing about for yet other forms of plant-life, I spy an enormous grapevine, one that has been figuring in all my life, for I love just as much to swing in it now at fifty as I ever did at five. Perhaps not quite so well, for the old familiar faces of forty years ago are now all gone, and not all retrospection is pleasant.

This grapevine where it leaves the ground, and for many feet, is eleven inches in diameter, and how long are the various branches can only be estimated. I tried such measurement once, but gave up in despair. I could only mark off one thousand feet, and the end was not yet in sight. How these vines climb to the tops of the highest trees and swing clear of the ground, often for one hundred feet between the tree and the root-hold of the vine, is not quite clear, but then who has traced the process from the beginning to the end? This grapevine is very old. It was here when the Indians were in possession; so much is positively known; but how much of a vine it was two 


\section{Wodben Grass is Green}

hundred years ago can only be conjectured. It is said a flint arrowpoint was found sticking in it years ago. Be this as it may, trees are cut down now at times that have arrowpoints embedded in their hearts. This is nothing strange. Arrows flew thick and fast at times in the woods, and that now and then a sapling should be struck is only natural. The tree would soon cover the stone point, and the shaft would be broken off.

One need not be a botanist to find infinite entertainment in plant-life; and it is not likely we will ever wander for long where plant-life is wanting. Remember that red snow is a plant, and birds carry seeds in the mud that sticks to their feet; so, if at sea, a bird might bring you both a plant and earth to grow it in. Then there are seaweeds, one that Bory St. Vincent says has branches fifteen hundred feet long; and even if we would we cannot get away from plant-life, for the late Dr. Leidy wrote a book entitled "A Fauna and Flora within Living Animals." It may be a little startling, but the microscopical anatomist can find out the trees and bushes that we carry about with us, as well as many a little animal. I say "we," for Leidy included man among the animals he studied when writing the book.

\section{VI}

THE heavy dew had not yet disappeared when, two hours after sunrise, I started for my walk. 
Every low cedar and spreading bush was glittering with bead-like dew, and although the summer has just begun, the autumn cries of many crows filled the air. The river shore had been much in mind since the recent flood, but I was not prepared for the changes wrought by it when at last, after wading and walking alternately, I reached the island. I had gone across lots, begged ferriage over the canal, and now for the first time in years was at the island's up-river end, where the elements are forever battling with Nature's effort to have things done decently and in order. Where had been grass, was now gravel; where had been a woodland tract, were now dead and prostrate trees. Where had been land was now water. How very marked is the instability of stable things! Since the ice age there has been an island and a river here, but perhaps our great-grandfathers would not know them now.

Know it or not, I knew it then and there as a good place for the forms of wild life I wished to see-" critters only a crank could care for," as old Silas Crabtree would say, giving me a significant look.

In the tangle before me: a mass of raw material for nature to make something new of, if she did not unmake it after getting started. This is a curious fate of many a nook even in this quiet country. They are always in a transition state. the rank growth of poison-ivy, only a few weeks 


\section{Tuben Grass is Green}

old, was the first marvel to attract attention. A few strands of this dreaded vine had come down the river, with trees or fence rails, and it was now again as flourishing as the day it left its home on the eternal hills. It does not poison me, nor the birds, so we agreed independently to thread its many tangles, and I to break it wheresoever I saw fit. Scrambling is better physical than mental exercise, and when perched at last on the trunk of an uprooted tulip tree, I was not in a receptive state of mind; but fate decreed otherwise, and sluggish senses were well aroused at catching a glimpse of a skunk.

I remember once a school composition written in a great hurry to prevent being "kept in." It ran thus: "The skunk is a beautiful animal and 'distance lends enchantment to the view." My teacher remarked I had said a great deal in a few words and let me off. To-day there was no distance to speak of, and I put myself on my good behavior, but was not sure of my near neighbor. $\mathrm{He}$ eyed me very critically for some seconds-hours, they seemed - and then ran into his snuggery, which was directly under where I was sitting. Affairs were critical. I had not quietly walked to my seat and could not noiselessly withdraw. Would the dreaded animal resent my scrambling above him and possibly falling down upon him. I admit I was a good deal disturbed, and the more so when the creature's mate came trotting along and, when 


\section{waben Grass is Green}

very near, similarly questioned why I was sitting on the roof of their house.

I began the retreat with extreme caution, but every twig snapped with the report of a pistol. Quiet restored, I moved a few feet more, and finally reaching apparent safety, fled for dear life. When at the river's shore and with bare sand to run over, I ventured to look back, and the skunks were just in sight, trotting in the opposite direction. The truth is they were more afraid of me than I of them, and had run under the tree and away as fast as they could. All that I had passed through was the penalty of jumping at conclusions. As I afterward learned, these animals had come down the river during the flood, and were as anxious to reach the main shore as I had been to escape from them, but did not venture to swim a hundred yards or more.

Breathing freely again and fearing nothing, I ventured again to scramble over the tangle left by the freshet, and found something finally greatly to my liking, a pair of least bitterns. These beautiful birds appeared to have a nest near by, but I could not find it. They came and went continually, however, and when they perched on the tree where I sat motionless, they made a pretty picture. There was so much attention paid to each other, and quiet utterance that I could scarcely hear, that I was sure they were mated, and as these birds remain until autumn is well advanced, associated in 
pairs, it is more than probable that they are given to permanent marriage, like their distant European cousins, the storks. It is quite certain that many species of birds are mated for life rather than for a season, and this obtains, too, among migratory birds. Of course there has been a great deal of ridicule heaped upon such a statement, but however glib the critic, he cannot alter facts; and not all the truth about birds is down in the professional bird-books.

By sitting very still, I was probably mistaken for a branch of the prostrate tree; at any rate, once the bitterns came within five feet of me, and I had my one excellent chance to note them carefully. They kept up a low chattering hum that seemed uttered without any opening and shutting of the beak. One of them had a snipe-like habit I had not previously noticed. It arched its neck, curved its back, and slowly elevated and half-spread its wings. I have seen the yellow-legged tattlers do this, and recently saw the same movement made by a female pintail duck, and but for the broad bill, the bird looked like one of our larger sandpipers, such as used to congregate in the salt marshes of our seacoast. A slight movement on my part startled the bitterns, and they flew off with a harsh cry and awkward flapping of the wings, very unlike their usual methodical flight.

The marsh-wrens next commanded my attention. They were not far off, and I had but to bring 128 


\section{Taben Grass is Green}

my field-glass into use to see them as if close at hand. Their globular nests fastened to the tall leaves of the cat-tail were not to be seen from where I sat, but the birds appeared and re-appeared with almost mathematical precision. They fluttered straight up into the air, and while on the wing, sang a few simple notes that have been very slightingly spoken of. But place and circumstance have much to do with bird music. Up in your garden these wrens would be simply chattering; but among the reeds, as I have said elsewhere, every note seems a drop of water that the bird charges with melody and then lets trickle back into the marsh. As I watched the wrens and listened to their songs, a larger bird even than the little bittern filled the field of my glass, and so appeared for an instant to be flying into my face. It was a curious experience. It was a green heron, one of the little company that have established a heronry in a sink-hole in an upland field. I marked its flight, and made sure of its going there, and then marked that it was time to follow. I had reached the island tangle at low tide, and now, where I had walked, I must wade, and where I waded, I must swim, or failing in this, must beg ferriage from some of the patient fishermen near by. I say "patient," for the man that rowed me to the main shore admitted that in five hours he had had four nibbles and one bite, but no fish. He left me to resume angling. What manner of man is this? 


\section{Waben Grass is Green}

\section{VII}

Wiтн a bewitching smile, and sweetly suggestive tone, Beatrice, with sketch-book and a new outing gown, looked toward the creek as she said, "I wonder if it is n't cooler over there among the big trees." Not even a graybeard could have resisted, and I simply succumbed. What did it matter if it was $90^{\circ}$ in the shade, and I had to do all the rowing?

We were soon ready for the start, but I let the tide carry us, and used the oars but little. While Beatrice sketched, I looked about in a double sense; for an excuse to go home and at the trees along the creek bank. Some of these, may I say, were wise in their day and generation, in growing so absurdly crooked that no man's ingenuity has solved the problem of making use of them; and then there were others that have happily been left by the landowners, until now they tower far above the stream and may be seen for miles. There is a shellbark hickory, eighty-two feet high; an elm with a spread of branches over one hundred feet, and a tulip-tree and ash that have been side by side for over a century, and are racing still to reach cloudland. But the smaller trees that filled every interspace had here a tropical look. The wild grape and Virginia creeper had climbed to their very tops, and I spied one tall sapling that was laden with bright red berries dangling on 


\section{Waben Grass is Green}

such slender stems that they were all a tremble, although not a breath of air was stirring. This was the Nemopanthes, and I was on the point of calling attention to it, when Beatrice-how like a girl!-screamed "Oo-oo-ooh!" that brought a vision of a horned owl. I started at the sound, and saw her pointing to a little pond by the creekside that was thick-grown with lotus. I did not wonder at her wild antics. It was a beautiful sight. Hundreds of huge circular leaves, like upraised umbrellas, covered the spot, and above them were superb pink flowers. To think that here, in a Jersey meadow, the sacred lotus of the East should be flourishing without the care of man! Of course we pulled in shore and examined the flowers more closely. Some one doubtless had planted a lotus tuber here, or it had stranded here after some freshet. It matters not, but the muskrats had not found it out, and now in the bottom of the pool was a network of roots that could defy the destructive rodents.

Once upon a time the native lotus flourished here, and even was cultivated by the Indians, for both root and fruit are edible; but the plant has long been extinct in the neighborhood.

While we were looking at the splendid flowers a humming bird came near, and buried himself in the golden heart of each flower, and emerging shook from his wings a perfect cloud of yellow dust. Then with a shrill squeak he passed to new 


\section{waben Grass is Green}

fields, and soon came back, but at no time squeaked such unmistakable disgust as when he attempted to sample the sweets of Beatrice's flower-topped hat. The poor fellow did n't know that the sweet flower he was after was just under the hat-brim.

With a boat-load of blossoms we were soon afloat again, and how valuable engaging conversation may be at times. I talked so rapidly about what we had seen that Beatrice did not notice which way the boat was heading until the bow gently touched the wharf, and suggested by the sudden arrest of progress that she look up. If I were not old, I should not care to encounter often such glances as hers at that moment; but then I am old, and knew that it was $90^{\circ}$ in the shade.

But the day was not over. We took the shady, hillside path homeward, and gathered blackberries as we passed clumps of thrifty briers, laden with fruit. I began to meditate again about Indians and our wild fruit, when Beatrice gave another scream, and I thought I heard the word "snake." This meant rushing to the rescue where there was danger, and I rushed manfully, on the principle that every man 's a sailor when the sun shines at sea. I found Beatrice, but where was the snake? I asked, and she timidly pointed to the bushes before her. Scanning them closely, I saw a pretty brown weasel looking directly at us, and how bright were its beady, black eyes! A 


\section{Traben Grass is Green}

slight movement on my part caused it to dart away, but we picked no more blackberries. A weasel is not always so easily driven off. They have been known to boldly attack men when the latter were tangled up in bushes and briers. Do they know that they have us at a disadvantage at such a time? Their well-known cunning leads me to think this. Two of them will act in concert and circumvent a ground-squirrel or a jumping-mouse, and so capture prey that would otherwise escape in many an instance.

We were glad to reach an open glade, with a huge, spreading chestnut. Here there was a breeze, and many a bird came hither while we rested. Though all were familiar to us, they were none the less welcome, and we wondered why even a song-sparrow never becomes tiresome. Have not pleasing associations to do with this? It is always nutty October and the painted woods when I hear the crows cawing; and if these birds are so destructive as claimed, which I do not believe, give me smaller crops and at least a few crows to perfect the coming autumn days.

"What bird do you like best? I 've heard you say a dozen different ones at as many different times," remarked Beatrice, who is never content with asking a question simply.

"What bird do I like best? I wish I knew. It is much like the case of the man who fell in love with twins, and was all unhappy because he 


\section{Wuben Grass is Green}

could not marry both. A good deal, I think, depends upon the time of day, and your own state of mind. The rose-breasted grosbeak suits the early morning hours, the song is so full of life, hope, and earnestness. It says "pitch in," and with the song ringing in your ears the day's labor seems lighter. For me, the wood-thrush is too melancholy. It is too suggestive of sorrow, too despondent, and yet we stand listening as if spellbound. Such is the contradictory nature of poor mortal man. We realize this when the cardinals come from some near-by thicket, and whistle as they only can. It is 'away with melancholy' with them and with us too. How the woods ring, and we might almost look for the old oaks to dance.

"There is another splendid, inspiriting songster that seems but little known. This is the Carolina wren. They take to our outbuildings as readily as the pewee or chimney-swallow to the chimneys, and what energy they have. Wren-like, they are never at rest, and when they sing they put forth all their strength. I have heard them when fully half a mile distant, determining this by actual measurement. This may seem an extravagant assertion, but it is not. Cope says of the bullfrog that ' it may be heard for a distance of several miles.' Now sound, of course, travels far over water, but the wren I heard sent its voice ringing through a strip of woodland and 


\section{Taben Grass is Green}

over a weedy meadow. When the day was still, I have stood on the bank of the Delaware, where the river was almost a mile wide, and heard the cardinal redbird whistling on the opposite shore.

"This Carolina wren will be very cautious at first, when building in any outbuilding, and will dart off precipitately when approached, but if it is not disturbed will rapidly gain confidence and become as tame as a chipping sparrow. Our birds, first, last, and always, ask to be let alone, and for this granted to them they will repay a hundredfold. While I write these lines there is an indigo-finch perched on a locust-tree, not twenty feet from my window. I can lean far out and listen without the bird noticing me. Why? Because it has been coming to the old garden for several summers, and no one has disturbed it in any way. It has nested near by, and no one has even looked into the nest. Like many another bird, they leave in autumn, saying, "We have had such a good time this year, we will come next summer.' And every year they make good their promise."

"Do the birds about our houses bring wilder birds near us, the former being unmolested ? "Beatrice asked, evincing some interest in the subject, or pretending to.

"I am inclined to think so. There are a good many species that, according to the older ornithologists and some more modern writers, are spoken 


\section{Wuben Grags is Green}

of as shy and retiring. Many of these I have not found so. They appear to gain confidence from what they see of the door-yard birds, but we should remember that these 'backwoods' birds have their peculiar needs, and some of them should be placed within their reach. I have touched upon this important subject in detail, elsewhere, and will only add, that the year that has elapsed since that essay was written has only confirmed my views of the matter as there expressed. It is our own fault, whether we live in town or country, if we do not have birds about us, and he who has them not dwells in an abode which, as has been well said, "is like a meat without seasoning." "

" Oh! dear, I did n't bargain for a lecture," exclaimed Beatrice, with a most suggestive yawn, but half concealed by her pretty hand; and then she asked, "What is that?" pointing to patches of old gold on the near-by meadows.

"Dodder," I replied, "the golden dodder's tangled net."

"Please don't repeat any of your own poetry; the weather is so warm;" so I essayed to tell more explicitly the plant's history, but was soon interrupted. " Now you 're too prosy," she remarked; "let us go home."

How hard it is to please our neighbors. If we describe what is everywhere to be seen in its true colors, the chances are we are charged with romancing; if we take these critics a-field they say 
we are tiresome and the wild woods are a bore. It is a vast pity, and I went home occupied with my own thoughts, as did Beatrice with hers.

A week has passed, and I have had a letter from Beatrice, and thus runs one of its sentences: "The rattle of the street-cars and rumble of the wagons here in New York were never so tiresome. How I wish I could again go with you on Crosswicks Creek and listen to your lectures! I 'd even face a weasel without screaming."

Let the whole truth be told. Old as I am, I have written for her to come again, and it will be but a repetition of what occurred in the first place. Puck was right: "What fools these mortals be!"

\section{VIII}

WHEN you are entirely satisfied that you have exhausted the subject, that there is nothing whatever remaining to be said, thought or considered, then remember it is time to go over it once more and gather up the important matter you have overlooked. I do not write this long sentence as a nonsense saying, but as a sober truth, for I have been taught the very important lesson that we are never sure that "we know it all," as the popular phrase runs.

I thought I knew the whole history of my home as it has been handed down from father to son since the original grant, but to-day I met an old 
man of whom I had never heard, a man nearly ninety, and what wonderful tales he told!

"Did you ever notice," he asked, "a streak of black running from the lane-field down to the brook?"

"Of course I have," I replied, "what of it?" "Well, a good deal of it to me, for while I never knew it as anything but a strip of sour, wet land, father did, and at the beginning of it was the little house he was born in, in 1778 ."

"Well, that's mighty queer," I remarked, more to myself than to him.

"He was a cripple, and moved away when only a little boy. This was how it came about. The war was n't over yet, you know, and whenever there was a strange noise they always thought the British were coming, and would run off with the cow or pigs. One night, in summer, the folks had gone up to your folks' house and left father asleep. They reckoned on coming back very soon, but got to talking, and the time rattled on, as it does now, faster than you think. Father woke up, and being sort of afraid, crept down to the door and opened it. It was pitch dark, and the lightning-bugs only made it seem darker, and the owls a-hooting made it lonesomer than ever. Well, father put on his clothes best he could and started to go to your folks, but he took the wrong path and went towards Watson's. It was more woodsy then, you know, and getting real scared, 


\section{Waben Grass is Green}

he set up a yell that made things ring. Just as he did that the old folks got home.

"Just then there came another yell, and the folks thought of bears, British, and a panther out of the backwoods. They did n't dare answer back, not knowing what the trouble was, and my grandfather said he would go on a still hunt. He took his flintlock and pitchfork and followed the sound. $\mathrm{He}$ heard the yell and started, saying to grandmother, 'You stay with the boy and keep the door barred.' The frogs and owls and other night things kept up the noise, so that what grandfather heard did not come quite clear, but he followed on, and pretty soon got a loud screech in his ear that made him shake. He got his gun ready and moved mighty slow, and when the scream came again he fired right at the spot. The flash of the old flintlock showed him his own boy, and he had put a ball in one of his legs. That 's how father got to be a cripple, and that is why the little marsh to the east of your house is called the 'cripple,' or was in my day."

I have played in this "cripple" many a day, and walk through it often in these later years, but all this was news to me. Still the old man was mistaken about the name. It was with him a mere coincidence, and had his father never been hurt the little swamp would have been called a "cripple" just the same. It was not necessary to set him right on that matter, however. It is folly 


\section{Wuben Grass is Green}

to say it is never too old to learn. His ignorance, considering his years, far better suited him than all the knowledge crowded in a dictionary.

I was not done with the old man, and he told me another story: "There used to stand an old oak on the hilltop with a crotch in it quite low down. Well, a deer was chased by two wolves out of the backwoods, and running this way made a leap for the meadows right through this crotched oak and got fast. The wolves' howling waked the folks up, and 'fore the deer was mangled the wolves got a load of buckshot and grandfather got the venison. They stuck a brick in the tree to mark the place, and less than twenty years ago I saw it in the stump where it lay at the foot of the hill."

I, too, have often seen the huge stump and the brick, and when I supposed every old resident was gone, here comes one to bring back the past and to tell me tales that even my own grandfather had forgotten to relate.

It seems strange, now that the world about here has grown so very artificial and tame, that such things as bears, deer, and wolves were ever about, and almost within the memory of a man still living; but with no records or tradition, the truth could have been reached in a rather curious way. The Indians were familiar with all these wild animals, and left their bones in the ashes of their long-abandoned camp-fires and in holes that they 
dug for the sole purpose of receiving the refuse of their villages. I saw such ashpits recently in nearby meadows, and what a curious medley was taken from them. Bones of bears and deer principally, but some also of nearly every one of our smaller animals, even to meadow-mice.

There was another story, too, that these diggings told. Many a bit of bone had been cut and ground down until it was a very effective awl or piercer, and some of the teeth had been strung for beads. With all these were hundreds of fragments of pottery, some of which had been tastefully ornamented with incised lines, dots, and cord-marks. One big piece had marks of a fishnet on it, and we know from Peter Kalm, who wrote a delightful book of travels about here in I749, that the Indians had nets, and the knots they tied were the same the fishermen tie to-day in making their nets. I have seen an impression of a knot made in wet clay which was so distinct that I could tell how it was tied; but when the Indian woman made it she only thought of its being an ornament to the bowl she had fashioned.

But to come back to the old man's stories. $\mathrm{He}$ had invested an ordinary field with additional interest, and I have looked up the spot where the house stood. I can only guess at the site, but where now is an under drain was a trickling brook that led from the spring at which these people of long ago got their water. How I would like to 


\section{Taben Grass is Green}

open it again, and plant an oak by it; but my matter-of-fact companion looked with scorn as I timidly made the suggestion: "Make another frog-pond, do; just to add to the noise that we have now, every night."

Alas! I fear that poetry and farming were not intended to go hand in hand; but I had my way in a measure, and under pretense of cleaning the drain dug down a bit, and found a little flat white stone that I am sure was just in front, and over which the cool waters trickled.

"Don't you see foot-prints on it?" I was asked. "And don't it smell of wet leather?"

"They went barefoot in those days, except the men," I ventured to remark.

"And they did n't go crazy over nothing, why don't you add ?"

The under drain still does duty as such, and I am content now to fancy that the fox-grape vine that grows by the brookside was once on a trellis, near the one-time cottage door, but this I kept to myself; for if I spoke of the clusters of fruit now clinging to it I would be sent in course of time to pick it for jelly. Better leave this to younger folk, and I will gather fruit from my neighbors, of which they know nothing, for every farm has bits of history that I love to bring to light, and then as local historian one gets a mite of importance in the eyes of others that tickles man's besetting sin, vanity. 


\section{Taben Grass is Green}

In natural history it is different. Too often it happens that the practical hunters and fishermen have the truth in hand, and what the naturalist assumes as a fact is only a fancy. It is well to apply to your own neighborhood with some care what is written in the books. It may not apply at all, and so the safe plan is to get the opinion of the people who are likely to know. Natural histories deal in generalities, and as every bird and beast has the problem of life to solve for itself, it will do so differently in accordance with its surroundings. It is not difficult to find many exceptions to the ordinary rule.

\section{IX}

How often it happens when walking in the woods in autumn, after all the summer birds have left, or the over-staying ones have become silent, that we hear a clear, bell-like peep pe-weep, just as we heard from the cricket, frog, or rattler in early spring or on some warm day in early March. It is not uttered by the same frog by any means. The sound often comes from the top of some tall tree or from the bushes, and never from the ground. You are apt to think of some belated warbler bound south and bewailing his misfortune.

This autumn minstrel is not a true frog, but a tree-toad, and is known to all naturalists as Pickering's hyla. It differs from the frogs proper by hav- 


\section{Tuben Grass is Green}

ing disks on the ends of its toes, and so can hold on safely to surfaces to which the little spring-tide rattler could not adhere. Pickering's hyla is an aquatic creature at the outset, but the waternursery is in time deserted and the hyla is not only a land animal, but an arboreal one at that. At times I have seen them on the ground among the dead leaves, but my experience leads me to conclude they are generally in the bushes or on trees. Certainly they are at home there, and you have but to attempt to capture one with your hand to realize what remarkable leaping power is theirs. This little tree-toad, which is scarcely an inch long, yellow, and with a crooked cross upon his back, makes a most interesting pet. It will live in a tumbler, with a few drops of water to bathe in at times, and asks no more elaborate rations than one house-fly a day. Given that much attention they will sing cheerily after their fashion and so loudly, perhaps, as to become tiresome. As you look at this little creature it impresses you by its general delicacy, and suggests that it belongs to the warm nights of summer and would succumb at the first touch of frost. But it is really our hardiest species. It often sings when basking in winter sunshine. I have often heard them when the weather was really cold, but the little hylas were not. They had sheltered nooks where only the sunshine could creep in, and when it did the hyla and the sunbeam made merry together. 


\section{$\mathrm{X}$}

I HAVE been watching men, of late, who were digging for relics of the Indians, and while the delightful November sunshine warmed me where I sat, I waited for the expected treasures continually brought to light by the spade. There was scarcely a shovelful of earth but contained traces of man's former presence here. Charcoal darkened the yellow sand, and although the potsherds were so small as to be readily overlooked, still they were traces of man just as much as the occasional complete vessel that came to light. I was much amused at a curiosity hunter that came by. $\mathrm{He}$ taxed our patience with endless questions, and forced me to be very rude at last. He had somewhere caught the phrase from one of those museum-lounging city archæologists, of "the desirability of additional evidence." This fool was not convinced even that we were unearthing Indians, and suggested that the charcoal might be from forest fires, and not from the cooking-site of aborigines. He felt insulted at last and passed on, to our great relief.

On my way home I thought of this fellow and it occurred to me that he was no worse than many others who in a more polished manner talk as he did, and are really far more of a curse to the community, because their polish gives them entrance to unsuspecting circles, and the poison of 
their ignorance and impudent assumptions warps the minds of all who hear them. These polished professors, without knowledge, with malice, and moved by ulterior motives in all they say, have concluded that the Indian is a recent comer to the Delaware valley. The truth is, the red man or his predecessor saw the glacial conditions that once existed here; but, as one of this oily fraternity remarked, "This must be determined by an expert." No definition was added as to what makes an expert. Not a fellow like himself, let us hope; for his skill has been all his life to pose as the polished professor of glittering generalities stolen from others, and with never a fact of his own gathering in his possession.

The men who have been digging near by have recently removed the soil over a considerable area, and on the hard clay underneath were found abundant traces of man, far ruder in all respects than those of the Indian dotting the overlying earth. It was evidence of that intermediate period, between the rude hunter of the glaciated river and the people with whom William Penn treated. The story of ancient man in America is told in all its completeness in this one river valley, that would boast of a clearer atmosphere were the doubting Thomases gathered to their fathers. 


\section{Out of the JBeaten IDath}

ISTENING to the creaking of a cricket is the 1 best recipe for day-dreams, and no daydreams in the country are so vivid as those of a still August day, when the fields are flooded with sunshine and not a leaf is stirring. Even the cows quit grazing at hot high noon and gather in the shade of wayside trees, or encircle the old oak that stands amid-field, sole survivor, it may be, of the woodland days, when fields were scattered and the forests clothed the earth. All that goes to make up the typical August day-and there are many such features-was prominent as I leaped the lane fence and wandered 'cross lots, glad to get out of the beaten and dusty path, from which the pedestrian is but too apt to be waved aside into deeper dust by the omnipresent wheelmen who appear of late to own all of such one-time pleasant places. Pedestrianism bids fair to become a lost art, more 's the pity. It is a matter of so many miles now, and not of so many pleasant sights and sounds. 


\section{Out of the Jbeaten Datb}

I leaped the lane fence and plunged into a wilderness of weeds. The tangled growth was no evidence of neglect or of poor farming, for the heat and moisture of the early summer have proved too much for the agriculturist, and many a spot I passed was rank as a tropical jungle. There was ragweed high above my head, and sensitive cassia almost waist-deep. Mullein stood out like the tree cacti of Arizona, and never boneset and catnip quite so flourishing. Bees were busy, butterflies were gay, and angry, in appearance at least, the myriad gorgeous dragon-flies that darted more erratically than lightning. I heard the harvestfly everywhere but near at hand, and at my feet the crickets creaked without ceasing. This constant insect stridulation does not pass for sound. It seems only to intensify the silence. We are conscious of it, yet without listening, and it ceases, or seems to, the moment an over-brave song-sparrow, or the tireless and tiresome indigo-bird essay to sing. Strange as it may seem, noontide song in August is misplaced music. It is more fitting to fill the void with the voices that fancy conjures up. The birds thought otherwise and sang gleefully when I reached a shady nook where the ground was moistened by a spring that scarcely broke through the sod. A sprightly cardinal whistled to its feathered friends to gather here, and eyed me with a questioning look, wondering if I had also accepted his invitation. I did not tarry 
to disturb his peace, for, seeing the weather-stained roof of an old mill in the distance, I made that point my goal of what at the start had been an aimless journey. Field after field, gorgeous in its August array, I passed over, and reached in time a commanding view of an almost hidden valley. What can be more inviting than an old mill and mill-pond? It stands the test of a true friend, it is never tiresome.

Nature has had ninety-two years in which to repair the damages caused by building the high dam that filled the deep ravine with water, and now the pond is a fixed feature of the landscape. The sloping banks have kindly adapted themselves to the change, and a narrow beach-line of wellwashed sand slopes outward for a little way and then disappears in deep, dark water. The whole shore is tortuous, and every jutting point well wooded; healthy oaks and vigorous hickories, with scattered willows, birches, dogwood, and flowering shrubs reaching so near the glassy surface of the pond that the trees are as clearly pictured beneath as they are darkly lined against the unclouded sky. Nothing remains of the original forest, and, following the lead of my fancy, I build from the sunken stumps of long-gone trees the forest monarchs that sheltered Indians in precolonial days. The dark and dreamy light in the narrow coves cast an eventide shadow over our noontide thoughts, and surely, when night draws 


\section{Out of the JBeaten Ipatb}

near, these same coves would be excellent spots wherein to meditate.

I have said that nothing of the old forest remains, but forgot for the moment that the old mill was built of it. Every one of the huge beams remains, and in its present home is as venerable as the lone wayside chestnut not far away, that tempts the weary traveler by its ample shade. The mill to-day seems more like a growth than an artificial structure. The huge foundation stones are like uplifted rocks, over which the criss-crossed beams have grown and still flourish. Then, too, to further the resemblance, there are the wide weatherboards, stained and streaky as the April skies; the moss-clad eaves, and even the huge wheel, with its dripping coolness, all of which have lost every toolmark and suggest nature rather than man's handiwork. The roar of the falling water at the dam is as primeval a sound as the rustling of the willows and broad-leaved catalpas that hedge it in. There is not a trace of glaring newness to be seen. Mill and pond, that once were scars upon the fair valley's face, have been so kindly dealt with by nature that the wound, long healed, has no traces left of the violence to which, nearly a century ago, it was subjected.

Pausing but for a moment at the door, I plunged into the dusky darkness of the mill's wide rooms, all a-tremble with the whirl and whiz of revolving shafts, hoppers, wheels, and what- 


\section{Out of tbe JBeaten Datb}

soever goes to complete a mill's machinery. I did not stop to notice what was about me, but sought an upper floor, where there was more quiet and a pretty outlook. Here was the dust of ages and of a long series of harvests, corn and wheat and rye, laid on in filmy sheets over walls and ceiling, and changing the slender threads of the spider to fabrics so delicate that a breath endangered them. Here was Thoreau's "dreamdrapery" in grand luxuriance, and but little more tangible than the mists that rèst upon Walden pond. In this unused room were the ghosts of unnumbered harvests, but not one of harvesters. How, for the time, I wished that human ghosts were something more than figments of the imagination. It was a fitting place to chat with the sickle-armed reapers of ninety years ago. As it was, I had nothing to build upon, for there was no old man of the neighborhood near to tell me strange stories of the place when he was young. Tragedy and comedy I felt lingered about the place, but who was there now to drag the mill's history from the clutches of oblivion? I asked about a dark red stain upon the floor, hoping to have a hint of dark doings in years gone by, but was assured it was "where my terrier Gyp killed rats one Sunday." Hearing this, I took to the woods, if a long row in my boat beneath the pond's overhanging trees can be so described. It was not so abrupt a change 


\section{Out of the JBeaten Datb}

as one might think. The pond and mill are too closely related to be dissociated in thought, and where nature holds undisputed sway one cannot weary. The head of the mill-pond, the most distant point from the venerable building, was as quiet as the mill itself when the water-gates are closed. The shallow waters, gatherings of many springs, teemed with life, and not a lily upon the quiet surface of the spot had lost its perfect purity. I was the sole invader, and how apt are uninvited guests to be awkward? Of course I brushed the wild roses where they were thickest set, and broke the stoutest stems of pickerel weed and arrow-leaf, placed where they showed to excellent advantage and gave the final touches to a perfect picture. Is our clumsiness a hint that man should stay at home? Near by was a little heronry, and every little green heron squawked its indignation. They looked at me, while perched upon the scattered dead trees that projected from the water, as if they had the wish, but not the courage, to pierce me with their sharp beaks. I sat quietly in my boat, hoping that they would gain confidence and accept me as a guest. I am glad now that I did this, for there were other herons there, as it proved, little blue ones, whose babies are white when they leave the nest, but, finding the world not rosecolored, get a fit of the blues and retain it all their lives. The unlearned ornithologists of our learned 


\section{Out of the JBeaten Datb}

societies declare that this bird is not common about this neighorhood, but the birds for years have paid no attention to the slight put upon them. There were but few other species, or was it too late for them to sing? I listened for the wood-thrushes, for here was an ideal home for them, but they were mute or absent; but soon the air was filled with an all-pervading twitter. Every nook and corner seemed alive with little birds, but the sound ceased as abruptly as it started -it was a passing flock of redwings that I heard. This intimation of the coming autumn always has a sobering influence, and the glitter of lilies and roses was a thing of the past. Summer's freshness, that I had not missed at the outset, I found was really wanting. There was more seed than bloom; more fruit than blossom; more limp, leathery leaves than the crisp growths of springtide. The passing blackbirds told the old story of constant changes :

What of the world, that we can claim

Is steadfast, year on year?

The very rocks stay not the same,

However they appear.

As quickly as the seasons glide,

Poor mortals come and go;

Death, the dark shadow at their side, They cannot overthrow.

The shadows reached nearly across the pond when I rowed back to the mill, and, seen in the 
sunset light, the old building was even more venerable than before. The hum of its machinery had ceased, the last farm wagon had left the low, sheltering shed, and the miller was asleep. It seemed a pity to disturb him, and I moved upon tiptoe as I locked my boat and put away the oars. I even felt a little ghost-like as I passed into the gloom of the mill's deserted rooms, nor wholly in touch, later, with passing events as I reëntered the sunlit-world, retracing my steps toward home again across lots and far as possible from the beaten path. 


\section{En Old JBarn}

SHADOWS and sunlight were racing over the fields, and why should I not run after them? It were no vainer quest than many that occupy our time and attention, whether in youth or old age. Then, too, though August, the day was cool, and the flecked sky above and mottled fields below were equally attractive. Whatever thy eyes find to see, see it with all thy might. There are hidden beauties that diligence may bring to light; and if the day's gathering is but a single pleasant thought, that day has not been spent in vain.

Every footpath way that I recalled still had novelty in store, and will have to the end of time. I had no fear of mere repetition of other days when I set out. Such is never the wise pedestrian's fate. The most familiar sights and sounds will prove new experiences if they suggest new thoughts; and this is always possible. Why should we tire of a familiar tree more than of a familiar face? It should be as pleasant to say "goodmorning" to-day as it was yesterday. I walked 


\section{An Old JBarn}

scarcely more than a mile before I reached the old barn of a one-time farm, that now stood quite alone. The land had been divided and sub-divided until nearly every original feature of the initial settling of the place was obliterated. It was but an old and empty barn; a simple structure of boards and beams that now trembled suggestively when the winds of winter hurried by and through it. Who built it I do not know ; who had labored to gather the harvests that it had held, I never heard; but what a world of suggestiveness in the moaning of the morning breeze as it struggled through the wide cracks in the walls, and caused to tremble many a loose board and mossy shingle. I peeped through one wide space, and what a hollow echo repeated my words, as I shouted: "Who's there?" I was sure that no one was near, but my voice called up a host of lurking spirits, or so it seemed. Here, indeed, was a place where fancy might run riot; but let us stick to the facts at present.

Oaks were everywhere abundant in colonial days, and the icy floods of glacial times had brought a few fragments of rocks to this neighborhood; enough for foundations, but never enough for walls; and so it happened all our barns are wooden, but they are little the less substantial. This one, in and about which I tarried, was still strong of frame, and if stripped by the storms of every trace of covering, could still brave 


\section{An Old JBarn}

the elements, fighting for life, as it were, in its bones. As it was to-day it had a dual interest, an historical or human one, and a natural or zoölogical one. Both merit some consideration.

I ventured across the one-time threshing floor, all scarred and dented with the flail's fierce blows, and then, with some misgiving, climbed the widerunged ladder to the mow above. There was need to be careful, and I stepped cautiously to the single square window that was but partly closed by what remained of its shutter. From here I looked down to get a bird's-eye view of the whole interior, and looked above to the decaying roof, through which the sun-bright sky peeped as so many stars. Thoughts came and went too quickly to be imprisoned, until I found, by chance, initials deeply cut upon the smooth oak sill on which I sat.

Four letters only, and yet how much of human interest centered about them? J. B. and A. S.! Some John and Anne of more than a century ago. And how easy to picture the hopeful John as he spent a leisure hour carving his own and her initials, building castles in the air as he did so! It was then, perhaps, that he cast away the last doubt in his mind, and courtship, a wedding, and home-coming followed. I vividly pictured, too, those later years, when the barn was the center of the farm activities; the oxen drawing the heavilyladen wagon, with its load of grain. It was al- 


\section{ZAn OID JBarn}

ways rye in those early days, and happy was the farmer who found that it threshed more than six bushels to the hundred sheaves. Men were gauged in those days by the rye standard, or by their capacity to withstand the subtle, ultimate outcome of the orchard. Occasionally there was a giant among them. I remember one who, in his prime, could in each hand lift by its throat a bag containing two bushels of rye, and carry them up a flight of stairs; and once, at least, he lifted a full barrel of cider by the chimes, and drank from the bung.

I take it this old barn saw its merriest days, or nights, when there were "husking bees," something unknown to the later generations, and, too, the dances that followed, when the broad threshing floor was cleared. There may have been a lack of grace and a heaviness of step that would distract a modern parlor knight, but there was a wholesome heartiness that made amends for such little deficiencies as I have mentioned. Not a phase of primitive farm-life but some feature of the old barn recalled. Nor was this all. Nature had taken possession, since all human care had ceased, and to see how the old structure was utilized by varied forms of animal and plant life was, to me, of even greater than its merely human or historic interest. Scarcely a nook or corner but was the home of at least spiders and those curious mason wasps that build such strange nests and 


\section{Zn Olo JBarn}

imprison paralyzed spiders within to serve as food for their young. The paper wasps, too, found lodgment for their many-celled structures. Crickets crawled and creaked among the loose boards, and huge night-flying moths sought refuge here by day, pressed so closely to the time-stained wood that only the sharpest eyes could spy them out. I have never seen better instances of protective coloring.

Two forms of active winged life were here, and what could more fittingly typify day and night than the beautiful barn-swallows and the dull, leathery bat? Nesting time was long over, but the curious mud structures, skillfully fastened to the rafters, were yet there, and still the birds, both old and young, continually came and went through many of the many exits in the dilapidated weather boards. On entering the barn they invariably circled about for a few moments before resting upon or near the empty nests, and often left the building without alighting anywhere. While on the wing the birds were comparatively silent, but chattered incessantly when at rest. At this time I could not positively distinguish between young and old birds, but saw no individuals feeding others. These swallows evidently retained a fondness for the nests, that were not really abandoned, for at night they roosted in and about them. They were homes as well as nests.

At one time the less abundant cliff-swallow 


\section{ZAn OID JBarn}

had built under the eaves, but this bird has no fancy for the inside of a building. How birds so similar in their general habits and not found fighting, species against species, should have come to vary as they do in nesting habits is very curious and, I imagine, an unsolvable problem. Before the days of barns they took up with hollow trees and caves, it is presumed, quarters they would find strangely cramped and uncomfortable now. It is not improbable that these swallows were by no means so abundant in Indian times as they now are. The changes wrought by civilized man in settling a country were certainly conducive to the general welfare of many small birds, by affording safe and convenient nesting sites and materially increasing the food supply. Man unintentionally but unavoidably gathers about him a great variety of plants, that in turn afford lodgment for varied insect life, and this attracts and sustains bird life. As an instance, no natural conditions were ever so favorable to many species of birds as is an apple orchard. Even now this is true, when the trees are frequently showered with insecticides. Happy the lover of birds who can spend a season near an old orchard; one with plenty of hollow trees. In one such, consisting of ninety trees, I found in one year the nests of thirteen species, not counting the nests, three in number, placed upon the ground.

But what of the birds, other than swallows, that I60 


\section{Fn OId JBarn}

frequented the old barn? Of course the pewee had been here, and the nest, occupied year after year for a generous fraction of a century, was in full sight from my window-seat. It would be interesting to accurately determine how long the same nesting-site has been occupied - of course by the same pair of birds. I can speak positively of one pewee, eleven years old, and have always fancied he had the same wife with him, year after year. The bluejays and golden-winged woodpecker came and went about the barn, but I did not see them enter. At times, doubtless, they do so, particularly in cold, wintry weather. Here, now, it is a mere matter of shelter, unless they sought insect food, for never a mouthful of grain has been put here for almost twenty years. Bluebirds of blessed memory - for they have been little else during the present year-were formerly constant visitors, and often nested in one convenient nook. These birds have largely disappeared. Comparatively few have been noticed for three or four years, and this summer I have failed to find one where formerly there were hundreds. It was their time-honored custom late in August to associate with king-birds and young orioles, and gather in the meadows and become for the time expert fly-catchers, or they would gather on the old worm-fences and stretch out, a large, loose flock, for half a mile or more. There was nothing of all this during the present summer. 


\section{ZAn Old JBarn}

It has been suggested that the bird is becoming extinct. Can this be true? Probably not, but rather they seem to have sought new quarters where the villainous feather-hunters and contemptible collector cannot find them. This seems the more likely because, late in October, we sometimes find the air, some bright, frosty morning, full of these birds, evidently migrating. A melancholy change of habit this, after many years when they were as strictly resident as our chickens or the nasty sparrows now in the city streets.

Rats and mice, too commonplace to be mentioned, and even the little weasel, the deadly foe of both, found in the old barn a congenial home, notwithstanding the most feral of domestic cats that I have ever seen here nightly made his rounds. Not one of these would rouse much interest, be the history thereof told never so cleverly. But bats, about which people know so little, always command attention. Several were sleeping in the old barn, and one that I disturbed was not long in regaining his senses, and flew about as easily as ever. At dusk he threaded the mazy tangle of an old forest's tree tops. Bats are not bird-like, although exquisitely graceful. They are suggestive of the uncanny conditions in nature, of gloom and hollow mockeries, of everything the opposite of bird life. Bats are living fossils, relics of a dead past that have escaped death, and no healthy mind can be buoyed, cheered, exhilarated by such 
creatures, in spite of what a hypocritical Yankee once said about them. To the naturalist, of course, these animals are interesting, and yet, strange to say, those who have studied them closely have not given us many particulars as to their habits. A beautiful monograph on the group by a prominent zoölogist gives every anatomical detail, but so little about the creature's ways and doings. Possibly did we know them better we might love them more. There is, however, one good word to be said for all our bats; every popular adverse impression concerning them is false: they will not tangle a lady's hair, nor do they bring sleep's deadly foe into the house.

It would require a small volume to tell how plant-life was utilizing the old barn. Gray lichen and green moss were both upon the roof. Virginia creeper, on the west, and a trumpet-vine on the east, had such firm hold on many of the broad, upright boards that they had been warped from their original support and were now held by the rank vines; one of these had ruddy foliage already, and the other, still in bloom, proved an attraction for the restless humming-birds that came and went continually. A poison-ivy clung to the hinges of the large double doors, completely concealing them. Pokeberry canes were clustered outside, ruddy and vigorous as a summer sun could make them; while a score of sickly, yellow-white shoots, which had thrust themselves 


\section{EAn OlO JBarn}

through cracks in the barn's wall, now lingered hopelessly in the unhealthy shade. Wherever water lodged and dust collected, seeds of small plants had taken root, and the choked gutter of the south front was as well filled with weeds as ever a long window-box was thick with bloom.

Even in the cracks of beams and boards, wherever exposed to the sunlight, seeds had found lodgment and germinated; and in one corner, to which the sunlight came but for a short time, but where there was pretty constant moisture, an acorn placed there by a jay or squirrel had sprouted. Necessarily its career would be soon cut short, and already a great mouse-colored spider had rather closely invested it with cobwebs. The wonderful change which nature was steadily effecting was just beginning, it is true; but, could the old barn remain, it would soon be more open than now to both sunlight and showers, and then what a rank growth would cluster about it, both within and without! Even the heavy threshing-floor would be lifted up and sturdy tree-growths push aside every obstacle. Strange as it may seem, unchecked vegetation can absorb or digest even so huge a mouthful as a barn. How clearly all that I saw hinted of that which is to come, unless man should interfere. Nature, with artistic fingers, has already cast a veil over the clumsy handiwork of man, and leaving to her the task, the old and once ugly barn would become really beautiful. 


\section{f TRockp TRoadgide}

THERE was a trembling mist and that dreaded 1 silence in the valley that foreboded the coming of a torrid day. The smoke rested as a heavy cloud behind the cars, and scarcely a leaf stirred as we left the station-Raven Rock-bound for a distant Indian quarry among the hills. There were three of us - a geologist, a botanist, and myself. Let me add that in this record of a day I am mostly concerned with myself. Autobiography is a simpler matter than history, and an August day calls for a light task.

We quickly passed through the village about the station, and while we saw many rocks we saw no ravens. Probably, from the jagged hillside hard by, some ravine has been miscalled, for the crows were now holding the fort, and where they are, ravens find no foothold.

Along a fairly smooth path we rose at every step above the river. The road was walled in shoulder-high and sadly circumscribed our outlook. We were forced to be content with the I I I65 
roadside rather than the rolling fields, with their infinitely varied features. Here every object was fixed, immovable, and I at once missed the scattered ice-transported boulders of the shifting sands of Jersey. We were on old ground, even geologically speaking; so old that upon it the forest grew when the ice was jammed in the valley and playing those pranks that now make the petty geologists quarrelsome. It was not surprising that the Professor could not refrain from telling the story of the ice-age as he had translated it. It is so clever, I had hopes never to hear another version. To listen to many leads to endless confusion. If possible, make your own translation. The truth, as he sees it, is plain to the individual who traces the figured rocks with his own fingers; but the gift of repeating what the rocks whisper is not yet among us, and this is true, likewise, of many another of nature's puzzles. The learned treatises that crowd the bookshelves are arrayed, not as a bodyguard of truth against ignorance, but each against his fellows. If we read all these books we have but the din of battle in our ears, and no vision is keen enough to pierce the smoke and see where victory rests. It is a sad mistake to become only a reader ; it leads to becoming only an echo. One excellent book is the blank one, to be filled by our own hands, so that in the evening of our days we can regale ourselves with morning thoughts. 


\section{A TRocky TRoadside}

Something better than the everlasting rocks were the transient flowers. To-day they were abundant. Clinging to the gray stone fence was the bittersweet, or better-known deadly nightshade. I doubt if the latter name is really merited, for the occasional eating of two or three of the berries has led to no harm, and so fine a plant should not be shunned as if pestilential, as is often the case. All too few are the plants that at the same time give us both fruit and blossom. This did so. The glossy red berries were peculiarly conspicuous, scattered over the pale gray lichens, and the purple and yellow bloom brightened and warmed many a jutting corner of the loose piled rocks. Responsive, too, to every passing breeze, the beauty of both fruit and flower was heightened when set trembling. That motion which has so much to do with the beauty of many plants seems to have been largely overlooked. A stiff, staid aspen would be an ugly tree. That splendid shrub, the nemopanthes, might possibly be passed by, even if in full fruit; but never, if there is a gentle breeze. Then every crimson berry on its slender stem sways to and fro, and your steps are staid to watch this carnival of color. And what more beautiful than those purple globes of frost-spangled eragrostis, the grass that in winter is rolled and tossed, the sport of every wind, until lodged fixedly at last, rods from its summer home.

Deadly or not, there were countless insects on I67 
the nightshade, and no defunct ones beneath it. They crept over flower and fruit alike, nibbling at both. It is true these creatures have white blood, and so no toxic effect would be produced as would or might be the case with red-blooded life; but the cow that disturbed our meditations cropped alike this vine and the grass beneath it, and no poisoning resulted while we were present, and doubtless not afterward. Indeed, it seemed a favorite plant just here. Great green and bronzed dragon-flies alighted upon it as well as upon the rocks near by. One gorgeous fellow appeared to sip the moisture from the bloom as might a butterfly. These splendid insects came and went continually. They did not skim the fields like low-flying swallows, but often rose far into the measureless upper air, and then, after towering far above us, going straight away,- not following the undulating fields,- - but sped across the valley more than a mile distant to rocks and nightshade on the river's other shore. I easily followed their direct flight with my field-glass. What humming and buzzing they made at times, like the roar of a great city, as though, like us poor mortals, they were burdened with many cares.

Beyond the nightshade grew a rank Virginia creeper, and summer must end far earlier on these hill-tops than in the valley; for plants are still in the vigor and freshness of spring on my lowland fields, while here the fruit shows, and I68 


\section{A Rocky TRoadsioe}

there is even now a goodly showing of reddened leaves. A gum-tree or tupelo, the top of which shows above the wall, is spotted with scarlet. It seems too early by more than a month for all this color, and may be due to local causes. Let us hope so. Still, as the breeze, though it stole very gently by, could not pass with silent footsteps, I heard a low murmur among the stones of this old wall that hinted of autumn, singing the same song that is whispered in the oaks, weeks later, when the freshness of summer has faded, and the leaves are dying and toughening to withstand for a little while the onset of frost.

While I yet lingered by the nightshade, the botanist clambered over the fence, and brought me tansy and mountain-mint. The fragrance of the latter recalled many an herb hunt in the summers of past years, when the good custom was still kept up to please the old folks, although the herbs had long gone out of use. For old time's sake, tansy, catnip, and balm hung from the beams overhead in the unceiled kitchen, giving out an odor that may have kept off the disease they were intended to cure. "It 's all doctor's stuff, nowadays," remarked Humphrey Fagan; "but folks die all the same, if not a little more so"- - and his flabby sides, that had weathered nearly ninety winters, would shake. I am ready to believe it. The "yarb teas," as everybody called them, were once in high repute, and deserved to be ; far more, 
indeed, than the highly potentized pellets of nefarious popularity. The fact is, granny has taken up more than one case the doctor had abandoned, and "tea - ed" the patient back to health and strength.

Although the geologist was a bit impatient, I waited for other gatherings of the botanist; but he began a long explanation of why meadowsweet was growing on the hill-top, and I made ready to start. I had use for his hands, not his mouth. There are thoughtless people everywhere, but think of lecturing in summer, and in the sunshine! What if the evening primrose was in bloom all the morning, and the meadow-sweet flourished in an upland field, can we not carry these contradictions unconsciously, and revive them, if we choose, when the snows of December make the long winter evenings fit for philosophical discussion? We do not need even to go over our note-books if we have any real powers of observation. These pictures can be recalled when we have time to attend to them. Even now the rank arnica that crowded about a wayside fence and hedged the barn-yard of a farm we passed stands boldly out on call, and so likewise comes back the remark of the farmer, who gravely told us, "them plants is good for hurts, so they say, but who 's goin' to get hurt just to see if it 's so?" and then he chuckled as though what he said was really funny. Then he became grave because we did not laugh, and asked, "Who be ye, anyway; 


\section{A Rocky TRoadside}

you don't look like tramps?" We were still unmoved to speak, which was really uncivil on our part; but when we had passed some distance down the road, I called back: "On a scientific expedition!" and we heard in reply a faint gurgle which we all thought might have been "Golly!"

The farmer was forgotten before the next house was reached. We saw, while yet afar off, that there was a well in the front yard, and, like unyoked oxen, we broke into a trot. We did not ask permission to drink, but opened the yard gate and passed in as though lords of that manor, and evidently no such ceremony was expected, for a tumbler was offered as soon as we halted and had sent the bucket plunging into the cool depths. To the good woman's surprise, we all courteously declined the glass, and how could we do otherwise when we saw the half of a cocoanut chained to the curb. Thank Heaven! at times we can forget about microbes. Why is it that even in such trivial matters the simplicity of the country proves so attractive? The geologist handled the shell as if it was the most delicate porcelain, when it could have been rolled down the mountain unharmed. Why should we be above country ways? Why, indeed, should any one? They are ways to which all desirable adjectives are rightly attached, and this is very far from being true of all city ways. It was no compliment to be taken for a man of the town, when all my life I have been 


\section{F TRocky TRoadside}

in fact, or in heart, a countryman. We had the water that we craved, and, renewed in vigor, surveyed the country from the standpoint of this open well. There was not a feature of house, or yard, or highway that was not old-fashioned, and I longed to spend my time here rather than go further. I did venture to peep around the corner of the house and get a glimpse of the old kitchen. A dark stone in the wall, near the peak of the roof, had cut upon it 1770 , and so tales of the Revolution might have been gathered from within its walls. But I was third fiddle to-day and of little consequence, only able to air my superior knowledge when I pronounced a little wooden vessel to be a piggin. The botanist tried to be funny, but being a Dutchman he could n't, and the geologist was warmed to a lively narrative. "I saw a city man seize a piggin once," he said, "as he would have snatched his own child from danger, and after a long, deep draught of wellwater, he said, ' Madam, I 'll give you ten dollars for that piggin. It 's the first time I 've been a real boy for thirty years.' The piggin cost him nothing and now hangs in his library." We are pretty sure, when drifting townward or when stranded there, to get, as it is called, above country ways, but, to my mind, it is a sinking below them.

The tall white pines that shaded this wayside cottage were remarkable objects. Both had been struck by lightning, deeply scarred but not seri- 


\section{A TRocky TRoadside}

ously injured; but, I judged, the enemies of these trees had all been killed. Never, outside of their native forests, have I seen the foliage of pines so perfect. It was distinctly blue rather than green, and every needle so long that each twig was bushy as a fox's tail. We stopped a moment longer to listen to that sad monotone, so marked a feature of the seaside forests. We plainly heard it. These lovely pines upon a distant hill murmured the same story of the untiring waves and never-resting wind that we now best hear near the resounding sea.

This was the highest point we reached, and probably not over five hundred feet above tide water; but even this slight elevation brings about many changes in anticipation of what occurs along the river shore, and in the low-lying meadows at home. The frosts of early autumn certainly make an earlier appearance, and so drive the insect-eating birds down to the valley. The vesper-sparrows and other small finches, from these hills, are among the earliest of autumn accessions to our avian ranks. In the longer-summered lowlands there is always a flight of visiting birds that have not the habits of the residents. They do not frequent the same localities and have no settled homes or purposes. They wander as if lost, twitter a great deal, and sing but little. These are the hill-country birds that flee from frosty nights and short rations. I noticed but nine species of 


\section{Z TRocky TRoadside}

birds during the entire day, but heard two or three others. Those I saw were meadow-larks, bluebirds, robins, chewinks, a cardinal, a pewee, many king-birds, vesper- and field-sparrows. All, save the king-birds, were in full song, and this was a surprise, considering the lateness of the season. The meadow-larks were livelier, clearervoiced, and more melodious, I thought, than any I had ever heard before. Doubtless the clear air had somewhat to do with this. These birds have forsaken the home meadows of late. Why, it is not easy to determine, for the region has not changed, except that weeds are more abundant. It is all pasture-land now, and not cropped for hay. Would this bring such a change about? For larks that were once so abundant are now quite scarce, and strictly, or nearly so, birds of the up. land fields. Slight are the variations in condition that result in the coming or going of our birds. The usual midsummer drought sends many a species from one locality to another, for abundant moisture is a prime necessity. Without it, the food supply is largely cut off, and so away go the birds. The summer of 1894 showed this; areas of many acres in extent were positively birdless, that but for the drought would be crowded from May to October with more than a dozen species. During the whole of August of that year I had to content myself with crows and chimney-swifts, and only in the few damp spots in the upland 


\section{A Rocky Roadsíde}

fields were there any native sparrows. It is true, goldfinches nested in the locust-trees by the house, but they kept so closely to the tree-tops, and fed in such far-off, weedy tangles, that they seemed much more like strangers than door-yard companions. Even the vireos found themselves too far from water, and usually stayed in the trees along the river shore.

The pretty chewink seemed to me quite out of place in a stone-fence, but was evidently at home, and the little trickling brook by the roadside that scarcely dampened the ground met all its needs. It che-winked as cheerily when threading the mazes of the loose-piled rocks as ever it did in the damp runways among the skunk cabbages, and, unlike the same bird at home, was quite indifferent to our near approach; and very tame, too, were the dear old bluebirds, that have generally forsaken many a former haunt. Very nat. urally, in accordance.with my observations for years, they were to-day closely associated with the king-birds, and proved as efficient fly-catchers.

It may be a bit perverse on my part, but to myself the ceaseless chirping of the crickets was really a more entertaining sound than the song of any bird. It was so thoroughly homelike, and recalled so vividly the lazy hours spent in the angles of the old worm fences in the lower country. I closed my eyes for a few moments in the shadow of the stone-wall here to let the crickets sing 


\section{H Rockn TRoadside}

to me of the weed-hidden fences that for years have had no caretaker except the strong briers that bravely uphold all the weaker panels. Such fences are the homes of many a small mammal, squirrel, weasel, and dainty deer-mouse, and the loud exclamation of the sharp-eyed botanist showed this was true of the stone-walls also. As a flash of lightning a red squirrel darted by, and a weasel followed, a close second in the race. The result is a matter of little doubt, for the weasel is still fresh when the squirrel is exhausted, and there are few places that it can reach, where trees are wanting, whereto a weasel cannot follow. Later we found where a vesper-mouse had been eating some large seeds, leaving a little pile of chips, about which a grim, gray spider had woven a tough web. This was funnel-shaped, and directed downwards to a dark crevice between two stones. We caught flies and one small beetle, and tossed them in; but their struggles did not tempt the crafty hermitess from her den; or, what is more probable, she saw us, and was suspicious. Outdoor spiders are extremely cunning. I think they have all the wisdom of the ant, and some mental traits of value in addition. I have not found them cowards, but discreet. They do not pretend to be a match for all comers, but rather very judiciously exercise their wits. It needs but scanty observation to be convinced of this, provided, of course, we take up the subject without preconceptions. Nothing so 
blinds us to the outdoor world as firmly rooted indoor opinions.

We now commenced descending the hill, and soon there was a beautiful hemlock grove in sight. We found on reaching it that the difference in temperature was fully twenty degrees. These hemlocks appeared as of recent growth, none of more than a foot in diameter, and so closely did they stand that their interwoven crowns shut out all sunlight. Every stone on the ground was damp and moss-clad, and the light so dim we could not well see to read. It is night here on a cloudy day. There were no birds flitting through the gloom, although certain warblers might have been expected in such a place. After some minutes had elapsed there was a song not familiar to me that resounded through the grove, filling it with music. The effect was strange. It seemed as if the original utterance was echoed and re-echoed without loss of volume. This strange bird, I felt sure, I had never heard before, or did the place play such a trick with the song as to deceive me? This is not an uncommon occurrence. I remember a pewee singing in a cave, and the song was more like the protracted effort of a thrush than the flycatcher's bisyllabic refrain. I wished to remain until the bird showed itself, but my companions demurred. They knew the tavern was near, and they were hungry. The poetry of the woods, the charms of the fair hillside fields, the grandeur 


\section{A TRockp TRoadside}

of the bright blue sky and majesty of the river that moved resistlessly through the winding valley went for naught. Even if they never reached the Indian quarry, these men must dine.

I had almost forgotten the prime purpose of our outing, and I think the botanist was equally culpable in this respect, and it came forcibly to mind that to dally any longer would have been unjust to the geologist, whose guests we were. Not a word of archæology had escaped our lips until we met at table, when our genial landlord assumed, as a matter of course, that three such looking mortals as ourselves, who never went near his bar-I did, afterward-could have no weightier purpose than relics, and so directed us to the quarry, saying, after we had reckoned with him, we "were not the first cranks that had come so far to see a hole in the ground." We followed his directions to the letter and went wrong, but found the spot by accident in trying to discover some way out of a wilderness into which we had blindly strayed. The creek the landlord spoke of was merely the dry bed of a stream that now rested under the frown of Jupiter Pluvius. The quarry, that had been discovered and discussed by prejudiced rather than learned men, was a commonplace affair, telling the same old story that has gone the rounds of periodicals and papers since the history of the Indian has been subject matter for discussion. Here, in brief, a stone suitable for arrow- 


\section{F TRockg TRoadside}

heads and implements of larger size and other purposes had been discovered and worked with more patience than skill. The spot was now a sad, silent, and long-forgotten one, eloquent of the past and of the Indian, but a mere matter of yesterday as compared with the age of ice and men who then lived in this same region. Probably a thousand years ago this quarry was the scene of a busy industry, and it may have been abandoned so recently as when the use of stone gave way to metal and the bow and arrow were laid aside for the gun. There was no clue to the exact history of the place, so we all sat about conjecturing, which is the sum and substance of American archæology. There was one fact connected with the spot: what it contained had nothing to do with the subject of man's antiquity in this river valley. That matter was affirmatively settled years ago in the lower valley, and nothing elsewhere has or can cast a doubt upon the matter. In short, the geologist, as I anticipated, had come on a wild-goose chase, one of many victims of those who for ulterior purposes have denied that the glacial gravels contain the relics that speak of man's antiquity. The truth has no rougher path than when forced to clamber over scoundrels. The geologist was disappointed in one sense, and not in another. $\mathrm{He}$ anticipated no upsetting evidence, but did hope for something more than a mere Indian quarry. He was rather sobered, 
for the walk had been long; but the botanist and I were merry, and by the time we reached the river bank and railway station, miles above Ravine Rock, the day was too far spent to attempt further learned discussion or give serious attention to anything about us. Happy time! We were our real selves again, and delighted to be natural, to be animals rather than mentals, and to drink in pleasure as we drew in the crisp air that came rolling like a flood down the rock-ribbed valley. For hours we had been lectured to and in turn had lectured, but now were as boys out of school, and who shall say what the practical folk thought of us, who, for many miles, were their fellow-passengers? I am sure they did not credit us with being in league with any ology. 


\section{Unp $\mathbb{P}$ earson's $\mathfrak{L}$ ane}

T $\mathrm{T}$ is not a long lane, but is now a very lonely one. It is as straight as a surveyor could plot it, and as level as any plane could smooth it. There are very ordinary fields on each side, and from no point of view is there a commanding outlook. Yet when you turn into it from the public road you draw in a long breath, and give utterance to an exclamation of delight. Do not ask why. That is a problem every one solves for himself when he happens here, and it is a red-letter day to any rambler to stroll up Pearson's lane, or loiter under any one of the old apple-trees in it. Let this fact suffice, and seek for no explanations. The old apple-trees: have these to do with the undoubted charm? It was in the spring of 1800 that a man, whom I well remember, celebrated his twenty-first birthday by planting twelve trees in the lane, six on each side. Five of the dozen remain, and when I last passed by they had fruit upon them. The trees lack little of being a century old, but the lane itself was opened by the original settler in $12^{*}$ I8I 


\section{Up Dearson's $\mathbb{L}$ ane}

1696. It was in May of that year that the Pearson who had come from England as a boy eight years before married and took his wife up this lane to a comfortable log house, wherein they dwelt for over forty years. It was the first notable incident since the opening of the new lane; an occasion as worthy of notice as the house-warming that immediately followed. There were no apple-trees then, but who can doubt that the grass was starred with sweet white violets? I have said the bride and groom went " up" the lane to the house. It was so put upon record on that very day, and also there was written, " and when I had seen the last of the Friends go down the lane to their several homes, I turned to Anne and said, "I trust the step we have this day taken may be for the best.' " Six generations have come and gone since then, and not one member of the fifth remains. It is sad, but true, that the world will not miss much when the sixth has disappeared. Then will come a change, and the lane will be blotted out.

Now, no one appears to hurry up or down Pearson's lane. So many dead men and women have been drawn slowly down its straight course during two centuries that all nature here has taken on a funereal pace. The apple-trees are slow in putting out their leaves, the blossoms are not ready until late in May, and the fruit is not mellow until November. The grass on either side of the single wagon-track is not the earliest green in the neigh182 


\section{Up Dearson's Iane}

borhood, but then such a sod! It has been undisturbed for two centuries, bear in mind, and is as soft and thick as the pile of good velvet. Nowhere else have I found such grass upon which to walk, or, preferably, to loiter.

As a rule, there is little to attract one when passing along an ordinary country road. There may be violets about our path, but these are commonplace; or buttercups in the fields, but these are everywhere; later, the thistle may be in bloom, with dainty goldfinches swinging from the stems, but many times before have we seen all this; there may be asters and goldenrod, joepye-weed and boneset, even pink centaury and dodder, and we will pass them by as a tiresome repetition of other days. Though unwise and illogical, our one thought is for novelty, for something to take us out of the line of common travel, away from the worn path of the prosaic millions who look neither to the right nor to the left, and think loitering a sin. Their example is no evidence that there is nothing to see even in the most commonplace of crowded thoroughfares. Then as children we were ever charged not to loiter, until the word became thoroughly hated, as detested as the practice was lovely; and it remains lovely, even in greater degree, as the rambler grows older. So when, weary of the commonplace, which is not to your credit, you chance to come to an old gate that has been swinging in all weathers until it is as fixed a feature 


\section{Up Dearson's Iane}

as the trees that shade it, you will promptly leave the highway behind you. It is but to take a single step and enter another world. This, at least, is true of Pearson's lane. Closing the quaint old gate behind you, you leave to-day with your neighbors and become a subject say of James II. or Queen Anne. It matters not if you are a stranger and know nothing of the place's history; the surroundings will keep you needfully posted. No one ever saw an old lane and did not know it was a thing of the past that held its own against the present - I would I might add, was sure to combat successfully with the future.

Now that we are in the lane, let us look about us. The first apple-tree that we reach holds us, of course. Its rugged trunk must be carefully inspected, its gnarly branches closely scanned. The warbler singing in its leafy top is no ordinary bird. Is not its song the echo of one that was uttered at least a century ago ? We fancy this, and the bird, at last coming into view, proves most appropriately as plain of feather as the good old Quakers of Penn's day were of garb, for this is the lane of a Quaker pioneer. If in spring, you pin an appleblossom to your coat as a matter of course, when no modern orchard bloom would ever tempt to such vanity. If in summer, you hear the humming of bees, but forget that there are such things, and listen with rapt attention to the buzzing of the big spinning-wheel, for the house is not far off. If in 184 


\section{Up Dearson's Lane}

autumn, you fill your pockets with fruit - if no one is looking - and eat as sour an apple as ever grew, thinking it sweet. If in winter and the dry twigs snap beneath your feet, you see at once the huge fireplace with its back-log, andirons, tongs and shovel, the crane and swinging-pot, and with every twig that breaks you have the crackle and snapping of the fire upon the hearth.

But we came not to see one old apple-tree, but the lane in which it stands, and we move on; and our steps are soon stayed, for here is another tree, even larger, and beyond another and another. We cannot pass them by. This one is hollow, and half the branches are mere shells, that have given shelter to owls and woodpeckers and are still the summer homes of wrens and bluebirds, the great crested flycatcher and the crested tit. If you have a taste for natural history, every hollow tree is a mine not likely to be worked out. This second huge old apple-tree had never been explored; and why did we come if not to fill out the details of the grand discovery, that of the lane itself? The woodpeckers are gone, but there may be an owl, and yonder is the snake-skin dangling from a hole, which means that a great-crest has been nesting there. Looking for the possible little red owl that is supposed to live in every hollow tree, I thrust my hand into one of the cavernous hollows. While feeling about its ridgy sides, my fingers come in contact with a small disk that 


\section{Up Dearson's Iane}

seems like metal; it yields to slight pulling, and proves to be a Washington penny. When the tree was young, it had doubtless been hidden beyond the bark, in accordance with a once widely prevalent notion that a coin so placed brought luck, provided the owner voluntarily parted with it and kept the fact a secret. I remember much of this silliness as prevalent in my own day; but children and pennies have been more prominent than the coveted luck.

We found no owls, but it is something to discover where they have been and are likely, in proper season, to be again. That they had feasted when last in the tree was evident from the handfuls of mice bones that I scooped from several of the deep holes in the trunk and larger branches. On this tree, too, were singing birds, one a most melancholy thrush, that, as my companion suggested, sang snatches of Auld Lang Syne. Now, this man was as prosy a mathematician as can be found, and yet he had actually caught the spirit of the place, or the spirit had caught him, and before we were at the last of the remaining old trees he bore some slight resemblance to a poet. $\mathrm{He}$ did not attempt any verses. Probably he had never read ten lines of poetry in his life. He did remark, however, "The quiet here is eloquent. I seem to be some other than myself. Why is it?" Simply what I have already said, but he, being mathematical and less receptive than common I 86 
folk, needed all these trees to influence him. Usually two or three are enough.

Perhaps I do him wrong. I did expect he would calculate the width of the lane on entering it, and estimate its length by staring down the wagon-track. To his credit, he did neither; to our discredit, neither had noticed the old worm fences that hemmed us in. It was only as we were passing from the lane to the door-yard that we saw them. But then who ever did see everything as he passed along lane, road, or wood-path, or across lots? We can only aim to overlook as little as possible.

It was just one hour later in the day when we left the lane and stood before the farm-house. This is such loitering as I dearly love, a whole hour given to just one furlong. No surly watchdog questioned our right, and no crabbed proprietor spoke to us of trespassing. The dog is a thing of the past, the several owners widely scattered, and the accommodating tenant not at home. We had but to people the place as we chose, and I, posing as local historian, proceeded to do so.

There was not a single feature of the old yard that was intact. This was fortunate. Any lingering newness robs all old objects of their charm. It is not enough to be old; they must look it. We were among ruins; not the product of sudden disaster, but the havoc brought about by long use, no attempt at repair, and the general ravages of 


\section{Up Dearson's Lane}

time and season. On every side we were surrounded by such ruins, and the pleasure of reconstruction was ours. Here, for once, the imagination had full swing, and how we reveled! What we did not know we fancied, and what we fancied we fell in love with. This is the proper business of loitering. Bent upon our own amusement only, our aimless method was not a loss of opportunity, and we were acquiring as much truth as does the professional historian by his scientific procedure. Does he not sometimes go astray almost as much as the woman who said she did not believe her folks ever cleaned flax with such a machine, looking, at the time, at the skeleton of a spinet? But the mathematician to-day made a bad break. Pointing, as he spoke, to a churn upon its cross-legged stand, he said, "That 's better than putting your barrel of wine on the cellar floor and having to stoop over to draw the liquor."

"That 's a churn, man," I replied.

"A churn? You were speaking of history; let me say that the distance between it and the truth of the matter is like that with which we deal in astronomy."

That was a neat remark, too good for a mathematician, and I told him so.

"They laid out their paths more with reference to convenience than to the garden landscape," my companion remarked. "See that crooked line in 188 


\section{Op Dearson's $\mathbb{L}$ ane}

the weeds, with bits of box-bush still struggling to keep alive."

"And they did well," I added. "Why forever stick to straight lines and turn sharp corners, as in Philadelphia streets? What a pleasing, winding way is even that short path from the kitchen door to the spring-house!"

"Spring-house! Let 's go." And away went the mathematician in a bee-line.

I followed slowly, and did not wonder at his enthusiasm when I reached the spot. In a little ravine there rippled a stream of sparkling water, cold as winter, beady as champagne. We could trace in the ruined brick-work where the milk-pans had been placed, and found, beneath a coating of moss and earth, huge slabs of stone that had formed the floor. I began gathering material for a romance, and my companion remarked, to himself apparently, "This reminds me of lines-"

"Well, boys!" from the lips of the old tenant, a queer man, but excellent of heart, cut short my meditations and my companion's remark.

On invitation, and for policy's sake, we followed the aforesaid tenant to the house. Halting on the door-step, I asked permission to explore the cellar.

"You 'll break your neck in the rubbish, for it's black as night down there; but you can go, of course." 
"Can I have a lantern ?"

"Yes, but don't smash it."

"Are you coming?" I asked of my companion.

" Not much," he replied, emphatically. "I 'll go back to the spring-house."

The feeble rays of the smoky lantern availed little against the darkness. It seemed as if no daylight had been here since I737, when the cellar was dug, and that year after year the darkness had thickened, so that now you waded through a condensation of gloom. It pressed upon you and fought the lantern's feeble flame until it dwindled to a pale red spark. By looking backwards I could see the steps down which I had come, so I was not lost, and I knew that this hole in the ground had narrow metes and bounds. The old man was right ; there was in it rubbish and nothing else. By dint of much feeling about, and casting occasional rays of light upon objects in reach, I made out, in one corner, what appeared to be part of a cheese-press, of itself of no moment, but there was a bit of an old book in it, and this I pocketed. Then on and on from corner to corner, but nothing strange or wonderful was found. Old garrets of late had become commonplace, and I had been hoping much from cellars as promising new hunting grounds. It was very provoking. As I neared the door I noticed a slight break in the wall, with what seemed the neck 
of a bottle projecting from it. Drawing it from its long-time resting place, it proved to be a quaint green-glass bottle of curious shape, one of the "Jersey Pines" glassworks product of more than a century ago. The lantern, at this moment, suddenly grew bright, as if it was thrilled by the discovery, and I read in the flash, "Currant wine, I802." I gave my lips an anticipatory smack, and, with a firm grip on my treasure, passed to the welcome sunshine, never thinking I was on another's ground

"What you got?" asked the old man.

"Oh, nothing."

"Too big for nothin', and in a bottle, too. Let 's taste."

There was nothing else to do, and, calling to my companion, we went into the kitchen. My precious wine must be sacrificed. I handed the bottle to the old man to open, which he did, pulling the bit of waxed corn-cob with his teeth quite dexterously. In the green glass tumblers that he had previously set out, no trace of the wine's color could be seen, and the atmosphere of the kitchen effectually prevented our detecting any fragrance, did it exist. The two tumblers were nearly filled, and offered us; we took them with thanks, and at the same moment brought them to our lips. Instantly they were withdrawn, and, with a bound that would have done credit to an athlete, the mathematician made for the spring-house, and I 


\section{Up Dearson's $\mathfrak{I}$ ane}

was less precipitate only because of my more sluggish limbs. What gallons of water it needed to wash away the horror that hung about our lips!

"Say, fellers," remarked the old tenant, for he soon followed us, "that was pretty tough. Seems to me that was hoss liniment, if I know the smell."

Somehow I did not care to talk as we strolled down the lane, and I noticed that my friend was not only morose but extremely mathematical in all his movements. Even his constant but suppressed exclamations of disgust and efforts to blow his mustache from his mouth were at regular intervals. Then, to make amends, as if the guilty party, I tried to divert his thoughts by recurring to events prior to the mishap, and asked to what lines he referred when we were interrupted at the spring-house. "Were they straight, curved, or crooked?"

"Not as crooked as your wine; but it was Wordsworth's lines that I meant:

A jolly place, said he, in time of old, But something ails it now; the spot is curst.

I believe it now." And he gave a vigorous blow at the hair which he fancied was still dripping with liniment. "Your fly-away method is all well enough sometimes, but it does n't hurt to mix it with a little mathematical precaution occasionally. You jump at conclusions, and then swear black is white in spite of the facts as subsequently de- 


\section{Up Dearson's $\mathfrak{I}$ ane}

termined. Of course it was only spoiled wine you 'll say, and not vile liniment."

"Why, of course."

"Well, it's a pity you did n't see the twinkle in that old codger's eyes when we turned into the lane."

"What did he say?"

"Say! Nothing; but he looked volumes." 


\section{Eี Dule= Tide Ramble}

THE distant river comes and goes as the sun1 light bids it. At times, a mere matter of faith, but now a glittering thread of silver wending its shiny way to the sea. But I take more kindly to the ponds and ditches. They come more nearly down to my level and are companionable to-day. The north wind passes overhead, and the sunlight creeps among the old oaks as if expecting to find me. It does, and we laugh together. Summer has left an abundance by which to remember her. We call it winter fruit, but it was the deft fingers of summer that shaped the bright red berries of the black alder which now replace the scarlet lobelia that in August blazed by the brookside. Then, too, there were the ruddy seed-vessels of the wild rose, and over the ground the golden fruit of the horse-nettle. The privet, laden with black berries, was still green, and the rhododendron and sassafras sprouts were fresh as a bright June morning, and beyond, the gaunt trunks of the walnuts were draped with 


\section{A Dule= Cíe tRamble}

climbing bittersweet, glowing with its wealth of crimson and gold. All this with abundant sunshine. What if it is December? It would be safe to wager there were flowers yet in bloom, I thought, and straightway found dandelions starring the dead grass.

Determine beforehand whither you will ramble, and make an early start. Sunrise I have always associated with mirth, and melancholy with the sunset. It is reasonable to do so. Be astir at sunrise then, and receive the greeting of that lover of the dawn, the blackcap. Chick-a-dee-dee means "cheerfulness," as he who hears it quickly learns, for the chill of the early hour is thereby tempered. Those who never see the world at such a time have strange ideas of winter. Frost is a gardener of most excellent taste, and when he has encased seed pods and dry grass with crystal all their beauty is restored.

No walk is so successful as that in which we make a discovery. It may be some trivial matter that we find, but this is of little moment. We have added to our own stock of knowledge, and this is often more pleasant than adding to the world's stock. There is no silly criticism to face, and when the walk is over there is abundance to think about, and the ramble reviewed at night before the andirons is a repetition of the day's enjoyment.

When, in the good Colonial days, this was a Quaker settlement and the folks were all neigh- 


\section{Z Wule $=$ Cide $\mathbb{R a m b l e}$}

borly, there were footpath-ways. Here and there some lone tree may be standing that was much more of a landmark to our forefathers than it is to us. Trees, I am sure, were something more than so many oaks and elms to the lovers of the last century. Be this as it may, they are trees only to us, and utterly without association of like import. The old-time paths have long since been blotted out, and so I hold it as my most excellent good fortune to find to-day a trace of one that was full of suggestiveness.

In a long-neglected corner of a high pasture meadow, to which none but the very highest freshets ever reached, there stands a curious group of trees, five in all, two willows, an oak, a maple, and a hickory. There is no great difference in their ages, and all are trees of the preceding century. I directed my steps toward them, more because they were the scene of a noisy gathering of crows than for any other reason that I can recall. Jays, a wary pigeon-hawk, and wandering robins flew above, and, I fancied, turned their heads when directly over me, as if they pitied any one who had to crawl upon the rough ground. I did not wonder. The hearty cries of these birds, as they dashed through the frosty air, expressed abundant joy. The call of the jay and whistling scream of the hawk, like the harsh plaint of the nuthatch and rattle of the flicker, accorded well with the surroundings, and bore the same relation 196 


\section{Z Wule= cíe TRamble}

to the bare twigs and nut-like fruit that the songs of summer birds bear to the leaves and flowers.

The clump of trees was deserted by the crows before I reached it, and when I stood in the weedy hollow between the five huge trunks, the spot was still as the sleepy churchyard with its charge. For the first time, though often here before, I noticed how strangely shaped were the trunks of the two willows, and closer investigation showed that they had overgrown a stile until at last they had quite concealed it. The wood of the two old willows was now so rotten, except for a little space next the bark, that the last efforts of a raccoon or opossum to effect a lodgment had broken away large pieces of the trees, and so exposed the stile. A path had at one time passed between these trees, and I could see the probable direction it extended; but why a path here, and from what point did it start, and whereto did it lead? These were hopeless questions. I doubt if any one now living knows; and what of the people who had passed to and fro in years long gone? Here, indeed, must have been a favorite spot for people to meet - by accident, of course - and we know that young Friends were equal to falling in love, and have been known to flirt. I have knowledge of one lively lass that could not be sobered by a drab gown, who was so frequently called to account by her elders that she finally got out of all patience, and very wisely, for her peace's 


\section{$\mathfrak{F}$ Wule $=\tau$ toe TRamble}

sake, married out of meeting. In a quiet way, this was a lively neighborhood; and the one-time footpath and stile in a little grove could tell a pretty story if they would but speak. But because abandoned now of men, it was by no means desolate. A troop of tree sparrows followed methey are usually quite wild - and pine-finches dropped from the clouds. The twittering of a hundred birds is equal to the single effort of an accomplished songster, and yet the guardian spirit of the place was not satisfied, and a Carolina wren came darting out of some dark hollow of the old willows and sang. The voice of this bird works a miracle. It is the magician's wand that transforms gloom to glitter, darkness to light, night to day. Winter stands back; the north wind checks its headlong course; the whole world listens with bated breath lest it lose a single note. What a yule-tide greeting was this, and in the one-time haunt of my own people, too, more than a century ago. There is something more in a bird's song than mere music.

It might be thought, I can readily see, that the effect of much bird-song would not be pleasant at this time of the year. We are so accustomed to think of winter as a season of rest and comparative silence, that any sudden outburst of joyousness grates upon us. It is untimely, and, so, untuneful. So much for your theorists and the dusty commonplaces of your feather counters and egg 198 


\section{z wule $=$ Tíe tRamble}

measurers. The birds do not look upon winter as most men do ; but man does not seem to have found this out. We have often more music in the leafless woods than when the foliage is at its freshest, at the flood-tide of its growth. Not the same music; in fact, with few exceptions, not the same birds, but this signifies nothing. It is music, none the less, and as heartily rendered as ever by nesting birds. There are those who say they have never heard this, but they forget there are hospitals for the deaf. The trouble largely lies in the fact that there is no radical cure for laziness. There is a vast difference between a summer stroll and a winter tramp.

We have many winter residents as well as allthe-year-round birds, and they are not disposed to remain forever quiet. A crested tit would rather be struck dead than struck dumb. Song is the very soul of a tit's existence, and I have never seen the storm that he dared not face and whistle his merriest when the north wind carried the mercury below zero. Bluebirds and song-sparrows, that are forever prated about as harbingers of spring, are just as merry and full of song in December as in April, and the latter are here to-day, as they have been ever since the species was evolved, for aught any ornithologist knows to the contrary, and will be until the end of time, unless collectors increase, or there is a total change of climate. The birds that really indicate the coming of spring 


\section{FA Wule= Cide TRamble}

and are not here now are less familiar than songsparrows, and, though finer singers, are not more welcome than the constant friends of all seasons.

As suddenly as they appeared, many birds about me as quickly departed. I could scarcely trace their movements, and in a moment they were out of sight. What could have frightened them, and where would they find safer quarters? I questioned myself thus, and soon had a reply, not from myself. A curious moaning sound from overhead, then a slight swaying of the tree-tops, then the blast of chilling air from the frozen north. How did the birds foretell its coming? I do not for a moment admit the possibility of mere coincidence. What is the character of the forerunner of these cold waves that appears to whisper so gently and hint so delicately that only a bird can understand the warning? In this case the change in temperature was very marked, though I did not mind it. It is always summer on the sunny side of the oak, and I betook myself to it. There was a glorious outlook over wide-spread meadows, and how gracefully the tall sedges and bleached grasses stand guard over the timid mice that venture abroad beneath them. Cunning and quick, yet not always equal to escaping the sharp eyes of the harrier or the marsh owl. There is poetry in the motion of most of our birds of prey, which even those who have most closely studied our outdoor world seem to have overlooked. A hawk 


\section{$\mathfrak{A}$ Wule $=$ Cide $\mathbb{R a m b l e}$}

is something more than a mere murderer. Our greatest ornithologist, Coues, has most appreciatively described their habits and individuality, but even he has omitted the hawk's ecstasy when caught in a gale. The wild scream of the redtail that I heard some days ago might need some modification, but would make a splendid chorus for a lively song. It was the fullest expression of exultation that I have ever heard. It was full of meaning and force, not a senseless jargon like a college cry. Our large hawks differ in their cries or songs, as I prefer to call them, but the variations are not easily described. One that I sometimes hear is an echo on the plain of a storm in the mountains; a crashing of timber and rending of rocks, softened by distance.

The sunny side of the oak was well known to a winter favorite, the brown tree-creeper, and he soon appeared, stopping very near my shoulder, and moving only a little way off when I turned my head. It is a mistake to suppose that these birds never rest during the day. If we watch one for an hour and see it constantly on the move during that time, we jump at the conclusion that it never rests; but it does. I have seen them cling to a bit of rugged bark and remain as motionless as a gray lizard. The one that ran to the sunny side of the oak while I was standing there did not remain quiet for more than a second at a time, except once, when it stretched its neck well 


\section{$\mathfrak{A}$ Wule= Tíe $\mathbb{R a m b l e}$}

out, and sang after its quaint fashion, as if thanking the sun for its warmth. It was the more interesting incident because the bird was running down the tree-trunk head foremost, like a nuthatch, a position not often assumed by the treecreeper.

But the world is something more than a birdcage, though I am apt to forget it when out of doors. Given one sunny nook of a bright winter day, and we are more apt to linger there than trust to finding others further on. But the land is full of them. Here, where the wind has full sweep, it is dotted with shelters; and the observer would be astonished were he to compare thermometers placed in the sun and shade. Even at night, I find by experiment, the warm daytime nooks are not so cold as the more exposed places, and here it is that so many birds roost. The smaller sparrows, at times, roost on the ground, where they are sheltered from the wind; but in milder nights I have found them in the thick-set shrubbery.

Leaving my sheltering nook, where the sun keeps the grass green all the year, I wandered to where, along the dividing fence that separates two tracts of meadow, there is a long row of gigantic sassafras-trees; not one but is over fifty feet in height. The trunks of many of them have been twisted from the very start, and are now of most 


\section{za wule= cide Ramble}

grotesque shape, while others are straight-stemmed, but with never a branch that is not crooked as a corkscrew. The leaves are gone, and the bare twigs stand out boldly against the dark-blue sky, suggesting that much might come of a study of twigs. They are as characteristic of trees as the foliage, or, if not quite, sufficiently so to make it important to the painter of winter landscapes. I have seen the top of one tree on the trunk of another in more than one pretentious picture. About the trunks of the sassafras-trees, supported by a villainous wire fence, was a dense growth of greenbrier, and here the thrushes had lingered until early autumn. Their nests were still intact, and one was occupied by a pair of white-footed vespermice, that had roofed the original structure, and now had a cosy home, through which neither wind nor snow could penetrate. Shaking the tangled vines until the nest began to tremble, I brought the mice to their door, which figuratively opened and shut so quickly that I could not see it. They came into view much as the drops of moisture gather on the outside of a glass, and, when on the outside of their nest, began to investigate me. As I stood perfectly still, one ran upon my outstretched arm, but at once realized I was of flesh and blood, and ran away with such haste I could not follow it. How they travel at all in such tangles has always been a mystery; 


\section{ZA wule $=$ Ctoe TRamble}

but they do, and how poorly language can convey any idea of their dexterity. As well attempt to measure the angles of a flash of lightning.

As yet, this has been an open winter; what if the weather be severe? The difference is much more with yourself than with what you will see or hear in a country ramble. You may need a thicker coat, but not so the chickadee or crested tit. I do not know but berries look ruddier and the rhododendron greener when the thermometer marks zero. The air is apt to be very clear at such a time; and, if still, the winter falcon may salute you with a cheery "good morning," though half a mile away. Certainly the snowbirds will go "piping down the valleys wild" just as they did when we had an Indian summer.

When homeward bound I looked about for some gnarly root of an old tree borne hither by freshets years ago, it may be, and now ready to fall in pieces. Such rubbish, as my neighbors call it, is the choicest firewood where there is an open fireplace with andirons. I found more than I could well carry, and selected one piece for a back-log that was as twisted as the serpents of Laocoön. How splendidly it turned to ashes a few hours later. It made for the time a pretty picture, and, while drawing the fire from a hickory coal until my pipe was well lighted, I was at least contented, if not a perfect picture of content. No! not altogether satisfied. The day's restlessness 


\section{F wule $=$ Cíde TRamble}

still lingered, and I could not keep my hands from the burning sticks. Such sticks are never properly arranged, and we must, or think we must, forever change their positions. It is a fascinating pastime; and what a dear, old Colonial ring there is in the clatter of the tongs! 


\section{Lanomarks}

Remove not the ancient landmark, which thy fathers have set.-Prov. xxii. 28.

Y text in Hebrew Scripture is more com1 pletely forgotten than this, and yet it merits as much consideration as the average quotation from Genesis to the Apocrypha. Everywhere we are removing landmarks; nowhere are we rearing them. But I write of the country, not the town, of which I know nothing. Scraps of old journals and quaint entries in time-worn commonplacebooks have given me an insight into the conditions of my own neighborhood two centuries ago, and it has taken only two hundred years to bring down the beauty Nature was long in building to the level of the commonplace. In the struggle for wealth we have made the land poor, and have not enriched ourselves. My neighbor has a large farm here in New Jersey, and spends the winter in Florida, that he may see the country. In other words, he robbed his own home, years ago, to pay the railroad and his board bill, and now bemoans 


\section{Ianomarks}

the barrenness of the landscape. He deserves to be kicked, and yet preserves the respect of his fellows; he even excites their envy. Another of my neighbors cut down four walnut-trees that he might enlarge his pigsty. After this there seemed to be no hope; for these men, who even shoot catbirds to save their cherries, who stuff their stomachs and starve their ears, are not to be reasoned with. For years, as I looked from an east window, I saw that group of walnuts, towering above the other trees, and in summer their leafy tops seemed like a huge ball that was rolling along the horizon, for trees on all sides hemmed me in. Now there is a break. I can see beyond, where I do not care to look, or, looking earthward, trace the roof of the new piggery. With the proceeds of his crop of pork, he too, this enemy of walnuttrees, is going to Florida. But even worse things have been done. Another neighbor has felled an old oak because the shade rotted the shingles, and now has a sunburnt door-yard, with a sickly arborvitæ near where the old tree stood,- - a very modest green tombstone of the fallen monarch. This neighbor never thought that his shingle roof might have been replaced by slates at about the same cost that was required to remove the tree. "But I sold the tree for a good price," he said to me. "And you gave away your credit for common sense," I replied.

Perhaps there is no landmark so suggestive as an 207 


\section{Lanomarks}

old tree. We are forever building monuments, but why not let those stand which Nature set up, even before the white man appeared upon the scene, and which were landmarks to our ancestors as well as to ourselves? We cherish Washington elms, Stuyvesant pear-trees, and Penn's treaty elm, because the men named once stood in their shade. Is it not as suggestive that an Indian once stood, it may be, under an oak and harangued his people? But, even if forsaken of all men, there is not a tree that has weathered two or three centuries but is as worthy of regard now as the scattered growths that happened to become associated with somebody's name. No mere association can the more ennoble a majestic elm. Because an oak, still standing, was riddled by bullets during the Revolution, it has no additional dignity. The murmur of the breeze through its branches is more musical than the whistling of hot lead. There is many an old tree still standing, but quite disregarded, because, as you say, it is nobody's oak or elm. No great man ever saw it or stood beneath its branches, so why should you? What rubbish! It is everybody's tree, teaching lessons, if you will but learn, that will greatly aid you on your journey through life. Tree-worship, once so common and still existing, is now accounted among us as trivial and evidence of a low order of intellectuality, even among savages; but it is not as belittling as our modern hero-worship. 


\section{Ianomarks}

A recent summer day bade fair to be all that a rambler could wish, and I was off early, for an allday stroll. Long before noon I met an old man from the town, and stopped a moment at his request. "The silver bells of the field-sparrows tinkle along the fences, just the same," he remarked, "but I hear no meadow-lark, and no wonder; the old landmark 's gone. In the middle of this field there stood an old oak, that was half dead when I was a boy, but it was here a year ago when I passed by. Never a May morning that I did n't hear the meadow-lark that stood on the very top and whistled. I heard him sixty years ago, and I heard him last spring. It 's all changed now with that landmark gone. How I wanted to see the old tree just once more!" And the old man turned away. It was a sad incident, and spoiled for me a fresh June morning. The old man's words kept ringing in my ears, and every warbler seemed to sing the same sad refrain,"the old oak 's gone."

I remember the tree. It was not so very large. There were no wide-spreading branches, but short, thick-set ones, that bent in upon themselves until the tree looked like a stout man with arms folded on his breast. Standing thus, it had weathered the storms of two or three centuries. It was once a corner tree, and is recorded as such in an old deed, so we have some clue to its age. But this is prosy history at best, and true of many others : 


\section{Ianomarks}

so what are the claims of old trees to our regard? Single one out, and study its career. Go to it in early spring and watch the swelling leaf-buds. This is the tree's busiest time, and yet how quietly it does its work! No one ever heard of a nervous or fretful tree. There 's a hint for you. I know a beech that yearly bears a half-million of leaves, yet their growth never made sufficient stir to deflect thistle-down from its course. Millions of drops of sap course through as many channels, yet there is no sound of moving water. It is in vain to press your ear against the bark; you will hear nothing; but the sap was passing upward all the while. No tree asks aid from its neighbors. It is self-reliant; and how much of that virtue can you rightly boast of?

We know that ere long the tree will afford us grateful shade; but did it make you any promise to that effect? You go to it, in fullest confidence, when the hot July sunshine scorches the fields, and you never are disappointed. Cannot mankind get a hint from a tree? Who ever lived that never spake of himself, never despatched a courier announcing his intentions, and never failed to meet the just expectations of his fellows? Death alone is the disturber of a tree, but man, with all his superiority, is the sole reason for such a word as vacillation. $\mathrm{He}$ is a poor student who can spend a day with a tree and go home none the wiser. I say this with confidence. As the tree 


\section{Iandmarks}

is instructive in proportion to its age, why not let it stand? Remove not the ancient landmark.

And what, too, of those mellow autumn days, when the green leaf, before its fall, rejoices in gay colors at the success of its mission? Though its last days have come, it sees no reason for mourning, but joins you in rejoicing that the expected but not promised - fruit has matured. Who that has gathered nuts, after a stinging white frost in October, but has learned to love the old shellbarks that are landmarks in the meadows? It is not childish to love an old tree. It is brutal not to do so.

But there are other landmarks than old trees. True ; there are old houses, and we add, perhaps, old men. The village without its patriarch is incomplete ; and what a difference between Colonial houses and those that have recently sprung into existence! We breathe in the odor of unpainted cedar and mossy shingles,- not strive to rid our lungs of the smell of paint. We seldom stop to look at a house built in our own lifetime; but how generally we scrutinize the old house near by, though we may have seen it daily for many years! Its quaint porch, the small-paned windows, the low eaves and substantial chimney, appeal to us, and we wonder if life is not more restful and soulsatisfying under such a roof. The old man in his high-backed rocker, dozing by the fireplace, the old woman knitting in her throne-like easy-chair, 


\section{Landmarks}

the willow-pattern china in the open cupboard,what a picture! But these venerable people cannot long remain, and then what? The children scatter the furniture, the old house is torn down, and we have the smell of paint and the chatter of strangers. Can we not at least preserve one such house in every village, furniture and old-fashioned garden and all else, keeping it for our children's sake, an illustration on the page of local history? What a poor exchange for this is a single chair or an odd plate upon the mantel of a new house! Detached from their proper surroundings, few objects retain their real beauty. It is like the caged canary as a substitute for the free minstrel of the wildwood.

The present rage for relics and indifference to landmarks are strangely inconsistent. I cannot understand that man who chases after a china teapot that he cannot authenticate, and allows his comfortable old house to be modernized. No one should be governed by his children in this. Let them be taught to reverence the old, and not fall down and worship the new. If you must prove that you had a great-grandmother, gather up the old crockery ; but pry not too deeply into its history. The cracked tureen that now holds the place of honor on the sideboard held soap-fat in the kitchen in Colonial days; but the old house itself was a monument to thrift and intelligence and patriotism: so let it stand, if possible, and 


\section{Ianomarks}

worry less about the trifles it once contained. We are not so land-poor that the new house must necessarily occupy the site of the old. Even in large cities, an old house, here and there, is as pictur. esque as an open "square." A bronze tablet in the wall of a new structure is at best but a reminder that we once possessed a treasure and threw it away.

But let us go back to the country. Where do we find those features that most surely attract attention and rouse more than a passing interest? Not on the main thoroughfare so much as along the back-roads. It is rare that any landmark is left when the road is a mere extension of the city street, without its pavements and long rows of dwellings. The welfare of vehicles and the convenience of horse-jockeys have alone been consulted, and every tree that encroaches beyond private grounds has been removed. The world is in too much of a hurry to go round an old chestnut. Though it has weathered two or more centuries, it has acquired no rights; no respect is shown to its age. Happily, matters are better ordered along the by-ways, and there we have ground free to all and not shorn of all its beauty. I passed along a back-road, last autumn, where nearly every fence-post was draped with crimson Virginia creeper,- where dwarf sumachs held aloft an abundance of ruddy fruit, and trailed between the lichen-coated boards of an old fence were wil- 


\section{ILanomarks}

lowy branches of climbing bittersweet, laden with crimson and yellow fruit. Not a bird of all the summer's host had forsaken the spot. After a wearisome ride along a dusty turnpike, with little that was natural to be seen, except the sky above, that back-road was a veritable elysium,- - a landmark for the old region thereabouts, which I trust no overseers of the highway will venture to disturb.

Remove not the ancient landmark which thy fathers have set, lest you force us to remain forever as strangers in a strange land. 


\section{Thoreau}

THERE are two of the many essays on Thoreau 1 that are probably more read than all the others put together, and because of their authorship - Emerson and Lowell - have greater weight in the minds of readers than would any expression of opinion from any other source as to Thoreau as a man of letters or as a naturalist. But the world is not always wise in bowing down to greatness, for greatness is very sure, in the long run, to overestimate itself. Neither Emerson nor Lowell was fitted to the task he undertook, though he doubtless thought he was. It is true that Emerson's article prefacing Thoreau's "Excursions" is a biographical sketch merely, but in it are phrases that are open to criticism. As an instance, take Emerson's estimate of Thoreau's ambition, or what he calls a lack of it. Now, so great is the influence carried with every word of Emerson that probably not one reader in a hundred but regrets that Thoreau preferred to be "captain of a huckleberry party " to leader of a political one, and that he held 


\section{Tboreau}

"pounding beans" to be better than " the pounding of empires." There is the error. What we sadly need is an infusion of intellect into the lower strata of man's activities. There will always be brains and to spare in professional life,-great leaders who will reach the artificial element that crowds the cities, and happily leaves undisturbed the simple folk who live nearer to nature. Thoreau would have been lost, or at best would have been but one of many, had he overcome his repugnance to mere formality, and met his neighbors in a dresssuit. We cannot imagine him acting any one of the innumerable white lies of modern society. In such slavish toggery he would have excited as much of ridicule as he now commands of admiration. In his lifelong battle for sincerity and simplicity, he knew the field upon which he was to fight; knew it better than any antagonist he met, and left it a conqueror.

As we glance over modern biography, we find there are countless examples of youth born in the ranks of the lowly who have aspired to better things, and seized knowledge as a cable by which to draw themselves upward, and spent their remaining days at a higher level and in an atmosphere that was but a source of wonderment to their ancestors. This sounds very noble; it is noble; but in Thoreau's case there was an inversion of this order, and the intellectuality that Emerson deplored as dissipated was put to the very highest 216 


\section{Eboreau}

of uses, that of making the lower or simpler things of life shine out in their proper light. By thoughtfully pursuing the occupations he chose, he raised them to the rank of professions, and clothed with dignity labor that before was drudgery. The quickest way to send the world to perdition would be to make all men lead professional lives, and the positive curse under which we now rest is that the absurdity is taught by parents to infants, and by teachers to scholars, that the true or best life is that of the preëminently learned, and that no dignity or honor or worthy reward of any kind comes to him who lives closest to Nature, and so most remote from the centers of civilization. Pounding beans, which Emerson sneers at, would not be degrading or belittling or unworthy a man of brains, if here and there a man of mental force would show that his brain and brawn need not come into conflict. If, over the land, Thoreaus would demonstrate that a day of toil in the fields can be followed by an evening of rational, intellectual enjoyment, the world would quickly advance beyond the present stage of agitation and unrest, that needs a standing army to preserve even the semblance of order. If the philanthropists would attack the problem of intellectualizing work, the workman would be benefited indirectly more than any efforts directed at "the masses" will avail. No work that the world calls for should be looked upon by a favored few as beneath mankind. More mis- 


\section{Tboreau}

chief lurks in a sneer than about a cannon's mouth. Thoreau stands for two conditions which neither Emerson nor Lowell nor any great man of letters or of science or of political economy has ever dreamed of displaying upon his banner : Simplicity and sincerity. This was an ambition far higher, far better fitted to secure the welfare of man and the permanency of his own fame (if he ever thought of the latter), than anything that Emerson ever thought of. Of course we must always bear in mind that Thoreau died before the youth of old age had commenced, and it is obviously unfair to pass too critically upon his writings. But two of the eleven volumes that complete his works were issued in his lifetime, and what he might have done with the mass that has since been printed, what omitted and what elaborated, cannot even be conjectured. That the best results should be realized, Thoreau should be read first, and what his critics have to say be considered subsequently; and it is to be regretted that, laudatory as is the biographical sketch by Emerson, it should have contained a single stricture. That stricture was not called for.

Lowell's essay on Thoreau, in the former's volume entitled "My Study Windows," though he claims his " most fruitful studies" to have been " in the open air," is eminently unjust. There was not the slightest trace of sympathy between the two men. Lowell is the reporter of the flower-garden; Thoreau, of the forest. Lowell can ride in a well218 


\section{Cboreau}

appointed boat down a safe stream, and report the graceful weeping willows that adorn its banks; Thoreau can sit cross-legged in a cranky canoe and tell in matchless language of the wild life that lives in dangerous rapids and lurks in the fastnesses of the untrodden wilderness. Lowell is tame; Thoreau is savage. The former tells us of a zoölogical garden; the latter of life in the haunts that Nature has provided. This being true, there lurked no cunning in Lowell's pen to tell the world who and what Thoreau really was. He simply gives us his own impressions, and they are erroneous. The well-known instance of Lowell, as editor, omitting from a manuscript of Thoreau's what he considered an objectionable passage, shows how widely apart these two men stood, and the act was an assumption on Lowell's part without excuse. What right, indeed, had he tacitly to assert that heaven lacked a feature Thoreau thought might be there? Neither of them knew, of course, one whit about the matter, but it is difficult to see why the bareheaded, sun-burnt, out-of-door Thoreau's opinion is not as worthy of consideration as that of his indoor, kid-gloved critic. It was a trivial matter, perhaps, but nevertheless a straw showing the direction of Lowell's thoughts, that Thoreau, because of his being a champion of simplicity and a foe to half that which Lowell cherished as making life worth living, could be snubbed successfully. But the world is growing wiser. There is more free- 


\section{Tboreau}

dom of thought than there was forty years ago, and perhaps no better evidence of true advance than the increase in numbers of those who now ponder as seriously over Thoreau's suggestive pages as they were once entertained by the polished periods of Lowell.

Extremes are necessary to effect great changes. No man ever yet drove a nail home, using only the exact force needed. There will always be an over-expenditure of enthusiasm. Thoreau always said more than he meant, knowing that, if he did not, his meaning would not reach home. He did not expect or wish a Walden hut to be built on the shore of every frog-pond. It was enough that his own experience should be an object-lesson for succeeding generations. We can carry a hermitage with us wherever we go, and meditate therein to our advantage. There are few men of culture but have or long to have their "den " where they are comparatively free from interruption. This is the meaning of Walden. He knew, well enough, that to be heard we must speak loudly to the deaf, and he shouted his best phrases where others have whispered and been unheeded. There is a roughness that is excusable on occasion. We do not ask the drowning man if his arm is sore when we firmly grasp it to save his life. If the reader is surprised at times at Thoreau's earnestness and plainness of speech, he must remember that he was a man with a purpose, and held his moments 


\section{Tboreau}

at their full value. There was no time to study what others had decided as the best methods of recording thought ; and yet, who has given us better specimens of pure literature than he? There is no other writer of our country who leaves the mind in a more thoughtful state, when we close the volume, than he does. This is just the difference between Thoreau and his critic, Lowell. The latter keeps us in a pleasant frame of mind so long as we read, but Thoreau lingers long after we have laid aside his books.

A very recent and ludicrous evidence of misconception as to Thoreau runs as follows: "Thoreau is as one of the lower wild animals, occupied with woods and mountains because he had under-. taken to get a living for body and soul out of them. Thoreau cannot be said to have loved, or sympathized with, any creature, neither the woodchuck whose meat he was after, nor the farmer whom he delighted to puzzle with conundrums about the cost of living, nor the Indian whom, a century ago, he would have slain on sight." If we take this simple statement as it is, not reading between the lines, it is worse than an absurdity, for it is positively and inexcusably false. Thoreau was the very prince of lovers; but of late people have lost the proper conception of honest love; and when we reflect how greatly he preferred an Indian who was what he claimed to be to white men who were not what they wished to be 
considered, the idea of his slaying a red man is indeed remarkable. Then this critic claims that others who have a fancy for the outdoor world are "more humane," and enter the woods with "more civilized" souls; but we must remember that these "improved" outdoorists say we must not ogle a bird but shoot it, to determine its identity. This is the humanity so much admired of late. If the bird-butchers, weighed down with "humanity" and "civilization," were extinct, and Thoreaus dotted the landscape in every direction, the world would be better off.

A word more concerning Thoreau as a naturalist. He was busied with the wild life about Concord when "Science" was still occupied with the hunt for new species, and content with a mere description of form and color. Evolution was but little discussed, and in New England much disregarded, because of the efforts of Agassiz to make it appear untrue. Thoreau made no practice of haunting museums, objects in alcohol or stuffed with tow not appealing strongly to him; but he did care to know, and was successful in ascertaining, the habits of the animals he saw. It is true he was anxious to know the scientific name of a plant that he had found, and, learning it, felt his interest grow; but this does not seem to have been a need as to animal life. It was enough to know that a given fish was a chub or a perch. The bream built a nest, scooping a hollow in the 


\section{Cboreau}

sand. That this New England "bream" was a percoid, and not a cyprinoid as is the English bream, and that it had a dozen Latin names given by as many authors from Linné down, did not interest him. He knew the birds as creatures to be met in various places, each with habits of its own, and its seasons of going and coming. This, rather than anatomy, was to him a matter of interest andimportance. To-day such facts are found to have a bearing on philosophical zoölogy quite equal in importance to anatomical structure. Thoreau did not add greatly to our knowledge of wild life, but he did that which is of equal merit, showed how delightful was the pursuit of such knowledge, and, in a measure, how it might be attained.

For many readers, perhaps for most, there is too little natural history in his books, too much of other matter. As we read, we feel at times a wish that he would sooner reach his conclusions on philosophical or political questions, because we are sure they will be followed by some bright reference to a bird or beast, simply phrased, yet so cunningly that the creature stands before us. Anybody can say or write, "I see a fox," but in Thoreau's books these same words are so framed in other matter that the animal leaps into view, and we see it dart over the snow, daintily carrying its splendid brush, perhaps looking partly over its shoulder at us, and leaving footprints that dot 


\section{Tboreau}

the author's pages, though he is eloquent over Greek poets, addresses a mountain, or weaves into splendid imagery the smoke that at sunrise he sees curling from his neighbor's chimney.

Thoreau had no predecessor and can have no successor. $\mathrm{He}$ was the product of conditions that can never again arise, for to expect another Concord with its galaxy of intellectual giants is utterly vain. He was one whose influence will last as long as our language shall remain. 
Ilnoex 



\section{Index}

A

Actinism of spring light, 47

Arrowheads, flint, I24

Apple trees, I8I

Arbor-vitæ, 207

Arbutus, 52

Arnica, I70

Arrow-leaf, I52

Ash, I30

Asters, 183

Aurora, remarkable, I2, 24

B

Balm, I69

Bat, 3I, I59

Beech, 52

Birch, 80

Birds and blossoms, 54

Birds, language of, II7

Birds, night-flying, I4

Birds, sleep of, $2 \mathrm{I}$

Bittern, 40

Bittern, least, I27

Bittersweet (Solanum dulcamara), I67

Bittersweet, climbing, 195, 2 I4.

Blackberry, 95, I32

Blackbirds, red-winged, I4, 20, I53

Bladderwort, 87

Bluebird, I05, I6I, I74, I85, I99

Boneset, I83

Bory St. Vincent, quoted, 124

Box-bush, 189

Bream, 222

Buttercups, 183

Buzzard, broad-winged, 69

C

Cactus, 148

Cardinal redbird, 48, 96, I04, Chickadee, 48, 195, 204 I 48, I74

Carp, 88

Cassia chamæ crista, I48

Cat, domestic, II, 34

Catbird, 57, 99, I03, II3

Catfish, voice of, $5^{8}$

Catnip, 169

Cat-owl, 6

Centaury, I83

Chat, yellow-breasted, I13

Chipmuni, 35

Chub, 222

Cobwebs, 36, I5I, I64

Cope, E. D., quoted, 85 , I34

Coues, Elliott, quoted, 201

Cricket, I06, I47, I59, I75

Cricket, leaf, 35

Crosswicks Creek, r 37

Crow, I8, I74, I96

Cuckoo, yellow-billed, 20 


\section{IIndex}

\section{$\mathrm{D}$}

Darkness, absolute, 25

Darkness, determination of objects in, Io

Delaware valley, rosy sunsets in, 3

Delaware river, varied aspects of, 46

Dodder, 183

Dove, 2I, IIO

Dragon-flies, I48, I68

Delaware valley, 3

Ducks, wild, 37

Delaware valley, ice-age in, Ducks, wild, whistling of, 56 I25

E

Elm, 24, 52, 208

Emerson, R. W., quoted, 2I5

F

Falcon, winter, 204

Finch, pine, 198

Fire-flies, 30

Fishes, voices of, 58

Flicker, I96

Flounder of Delaware river, 60

Flycatcher, great crested, 99, III, I85

Folk-lore of Indians, 67

Fox, 36, 75, 223

Frog, bull, 25

Frogs, cries of, 59

G

Glow-worms, 3I

Goldenrod, 183

Goldfinch, I75, I83

Grakle, purple, 99

Grapevine, 123, I30

Greenlet, white-eyed, ro3

Grosbeak, rose-breasted, 22, 57, IIO, I34

Gum-tree, 80, I69

H

Hare, 36

Harivansa, quoted, I03

Hawk, black, 69

Hawk, marsh, 68

Hawk, pigeon, I96

Hawk, red-tailed, I8

Hawk, sparrow, 69

Hawks, voices of, 201

Hemlock, 50

Heron, great blue, I3, I8, 39

Heron, little blue, I52

Heron, green, I04, ${ }^{5} 2$

Heron, night, 40

Herons, 20

Hickory, shell-bark, 9, 74, I30, I96

Houstonia, II9

Humming-bird, I32, I63

Hyla, Pickering's, I43

I

Ice-age in Delaware valley, Indian village-site, ancient, $\mathbf{I}$, I25

Ignis fatuus, 25, 27, 29

Indian pottery, Io9

Indian quarry, $\mathrm{I}_{7} 8$

Indian summer, 204

I45

Indians, Delaware, I6, I49

Indians, Delaware, refuse heaps of, 93

Indigo-bird, $96,99, \mathbf{1} 48$

Ivy, poison, 125, I63 


\section{Index}

$\mathrm{J}$

Jamestown weed, 16

Jay, blue, 18, I6I, I64, 196

Joepye-weed, 183

K

Kalm, Peter, quoted, 4I, I4I Kingfisher, nocturnal habits Katydid, 35

Killdee, I3

King-bird, 98, I6I, I74

Kingfisher, 18 of, 67

Krakatoa, volcanic disturbance at, 3

L

Landmarks, 206

Lark, meadow, I74, 209

Larks, horned, 9

Leidy, Jos., Dr., quoted, I24

Lenâpè language, 67

Light, springtide, 47

Lightning-bugs, $3 \mathrm{I}$

Lily, pond, I52

Linné, 223

Liquidambar, 9,38

Lobelia, scarlet, I94

Lotus, 86, I3I

Lowell, J. R., quoted, 2I5

M

Maple, I96

Maple buds, frozen, 49

Marsh-wrens, 8I

Martin, purple, 80

Maryland Yellow-throat, 19

May magic, 52

Mink, 24, 63

Minnows, $9 \mathrm{I}$

Mint, mountain, I69

Mistletoe, I20

Moonlight, 32

Mosquitoes, II 5

Mouse, deer, 23, I76

Mouse, house, I62

Mouse, meadow, 22, 75

Mouse, vesper, 8,203

Mouse, white-footed, 23

Mouse, wood, 23

Mud-turtle, $9 \mathrm{I}$

Mullein, I48

Music, animals attracted by, Muskrat, 63,86

Muskrat, winter houses of, 87

Muir, John, quoted, 9

$\mathrm{N}$

Nemopanthes, I3I, I67

Nettle, I6.

Nettle, horse, 194

Night, definition of, I

Night-hawk, 4I

Nightingale, 67

Nuthatch, white-bellied, Ig6

$\mathrm{O}$

Oak, I96

Oak, red, 6

Oak, white, 208

Oaks, 156

Octopus, 88

Opossum, 36

Oriole, 8I, 98

Otter, 63

Owl, cat, 6

Owl, little red, 7, 7I

Owls, 18, 22, 25, 34, 185

Owls, as origins of ghost stories, 7 


\section{Index}

$\mathrm{P}$

Pewee, I00, I6r, I74

Pewee, wood, I9, 3I, 65, I34.

Phlox, Ixg

Pickerel weed, 86, I52

Pine, white, I72

Plover, I3, 20

Poaetquissings Creek, 24

Pokeberry, I63

Privet, I94

Pullen, Bill, hermit fisherman, 42

Q

Quail, 2I

R

Rabbit, 75

Raccoon, 36

Rat, I62

Raven Rock, I65

Redbird, 48, 96, I04, I48

Red snow, I24

Redstart, I9, 8I, I00

Rhododendron, 50, I94, 204

Robin, I9, 99, I74, I96

Rose-mallow, 86

Rose, wild, 152, 194

S

Salamanders, Io9

Sassafras, 9, 194, 202

Scuttle-bugs (Gyrinus), Ir2

Sea-serpent, 88

Shell-bark hickory, 9

Skunk, 23, 126

Skunk cabbage, I75

Snake, black, I08

Snake, copperhead, I07

Snake, garter, I07

Snake, green, Io7

Snake, water, 63

Snow-birds, 75, 204

Sparrow, chipping, 99

Sparrow, English, 99

Sparrow, field, I74, 209

Sparrow, song, 49, 65, 100, I04, II3, I33, I48, I99

Sparrow, tree, 5, 75, I98

Sparrow, vesper, I7, I74

Sparrow, white-throated, 8

Sparrows, 22

Spiders, I58, I64, I76

Spring beauty, II9

Squirrel, flying, 8

Squirrels, 34, 164, I76

Sturgeon, voice of, 58

Suckers, 58

Sundew, I22

Sunflowers, 39

Sumac, 213

Swallow, barn, I59

Swallow, chimney, r34

Swallow, cliff, I59

Swallow, white-bellied, 80

Swift, chimney, 20, 3I, I34, I74

T

Tansy, 169

Thistle, r6, r83

Thoreau, H. D., quoted, 97, 103, $107,1_{51}, 215$

Thrush, brown, 99

Thrush, wood, 65, I53

Tick, yellow, 39

Tit, crested, 22, I04, I99, 204

Toad, 32, 83

Toad, spade-foot, 79

Tortoise, box, 92

Tree-creeper, 201

Tree-sparrows, 5, 75

Trumpet-vine, I63

Tulip tree, I30

Tupelo, I69

Turtle, mud, 9I

Turtle, painted, 92

Turtle, snapping, 43, 92, I05

Twilight, I 


\section{Index}

U

Utricularia, 86

V

Violet, dog-toothed, II9

Violets, 183

Vireo, red-eyed, I13

Walden, Io3, I5I

Walnut, I94, 207

Wasps, I59

Water-bug, giant, 95

Weasel, 8, 23, 75, I32, I62, I76

Whippoorwill, 3I, 42

Will-o'-the-wisp, 25, 27

Willow, I96
Vireo, warbling, 99

Virginia creeper, I3o, I63, I68, 2I3

W

Woodpecker, golden-winged, I6r

Woodpeckers, I8, I85

Wood-pewee, I9, 3 I

Wood, phosphorescent, 29

Wood-thrush, 65

Wren, Carolina, 22, I05, IIo, I34, I98

Wren, house, 99, I00, I04, I85

Wren, marsh, I28 



$$
2 \times 8
$$






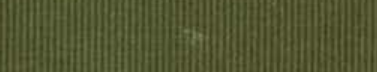

